Prepared for the U.S. Department of Energy

under Contract DE-AC05-76RL01830

\title{
100-NR-2 Apatite Treatability Test: An update on Barrier Performance
}

BG Fritz

VR Vermeul JS Fruchter
JE Szecsody

MD Williams

May 2011

Pacific Northwest

NATIONAL LABORATORY

Proudly Operated by Battelle Since 1965 


\title{
DISCLAIMER
}

This report was prepared as an account of work sponsored by an agency of the United States Government. Neither the United States Government nor any agency thereof, nor Battelle Memorial Institute, nor any of their employees, makes any warranty, express or implied, or assumes any legal liability or responsibility for the accuracy, completeness, or usefulness of any information, apparatus, product, or process disclosed, or represents that its use would not infringe privately owned rights. Reference herein to any specific commercial product, process, or service by trade name, trademark, manufacturer, or otherwise does not necessarily constitute or imply its endorsement, recommendation, or favoring by the United States Government or any agency thereof, or Battelle Memorial Institute. The views and opinions of authors expressed herein do not necessarily state or reflect those of the United States Government or any agency thereof.

\author{
PACIFIC NORTHWEST NATIONAL LABORATORY \\ operated by \\ BATTELLE \\ for the \\ UNITED STATES DEPARTMENT OF ENERGY \\ under Contract DE-AC05-76RL01830
}

Printed in the United States of America
Available to DOE and DOE contractors from the
Office of Scientific and Technical Information,
P.O. Box 62, Oak Ridge, TN 37831-0062;
ph: (865) 576-8401
fax: $(865) 576-5728$
email: reports@adonis.osti.gov

\author{
Available to the public from the National Technical Information Service, \\ U.S. Department of Commerce, 5285 Port Royal Rd., Springfield, VA 22161 \\ ph: (800) 553-6847 \\ fax: $(703) 605-6900$ \\ email: orders@ntis.fedworld.gov \\ online ordering: http://www.ntis.gov/ordering.htm
}

This document was printed on recycled paper. 


\title{
100-NR-2 Apatite Treatability Test: An Update on Barrier Performance
}

\author{
BG Fritz JE Szecsody
}

VR Vermeul MD Williams

JS Fruchter

May 2011

Prepared for

the U.S. Department of Energy

under Contract DE-AC05-76RL01830

Pacific Northwest National Laboratory

Richland, Washington 99352 



\section{Summary}

Following an evaluation of potential strontium- $90\left({ }^{90} \mathrm{Sr}\right)$ treatment technologies and their applicability under 100-NR-2 hydrogeologic conditions, the U.S. Department of Energy, Fluor Hanford, Inc. (now CH2M Hill Plateau Remediation Company), Pacific Northwest National Laboratory, and the Washington State Department of Ecology agreed that the long-term strategy for groundwater remediation at the 100-N Area should include apatite as the primary treatment technology. This evaluation indicated that the apatite permeable reactive barrier technology had the greatest promise for reducing ${ }^{90} \mathrm{Sr}$ flux to the Columbia River at a reasonable cost.

In June and July 2008, full-concentration, apatite solution injections were performed in support of the initial phase of barrier-emplacement operations for the 91-m (300-ft)-long apatite PRB section. Injection performance and 1-year of monitoring data were described in a previous report. This report updates the performance monitoring of the permeable reactive barrier (PRB) with an additional year of monitoring results, providing 2 years of data following initial treatment with full-concentration, phosphate amendment solutions.

Following completion of the initial phase of PRB emplacement operations, ${ }^{90} \mathrm{Sr}$ concentrations measured at the compliance monitoring wells trended downward for about 1 year. However, in the second year of monitoring, between August 2009 and October 2010, this trend has reversed, and small increases in ${ }^{90} \mathrm{Sr}$ concentration have been observed. Although ${ }^{90} \mathrm{Sr}$ concentrations have increased slightly over the past year of monitoring, aqueous concentrations are still being maintained at levels well below the pre-treatment levels. It is recommended that aqueous performance assessment monitoring be continued at the same frequency to better understand the observed increases in ${ }^{90} \mathrm{Sr}$ concentration and quantify longer term trends. 



\section{Acronyms and Abbreviations}

$\begin{array}{ll}\text { BHI } & \text { Bechtel Hanford, Inc. } \\ \text { CERCLA } & \text { Comprehensive Environmental Response, Compensation, and Liability Act } \\ \text { CHPRC } & \text { CH2M Hill Plateau Remediation Company } \\ \text { DOE } & \text { U.S. Department of Energy } \\ \text { DOE/RL } & \text { U.S. Department of Energy, Richland Operations } \\ \mathrm{ft} & \text { foot (feet) } \\ \mathrm{FY} & \text { fiscal year } \\ \mathrm{L} & \text { liter(s) } \\ \mathrm{m} & \text { meter(s) } \\ \mathrm{mg} & \text { milligram(s) } \\ \mathrm{mg} / \mathrm{L} & \text { milligram(s) per liter } \\ \mathrm{OU} & \text { operable unit } \\ \mathrm{pCi} / \mathrm{L} & \text { picocurie(s) per liter } \\ \mathrm{PRB} & \text { permeable reactive barrier } \\ { }^{90} \mathrm{Sr} & \text { strontium-90 }\end{array}$





\section{Contents}

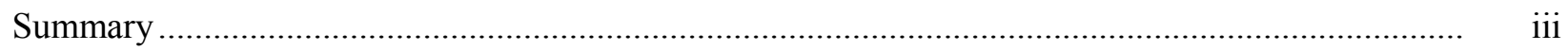

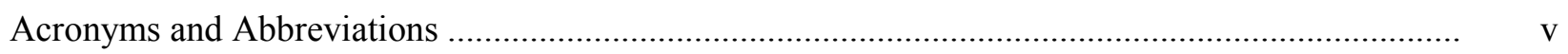

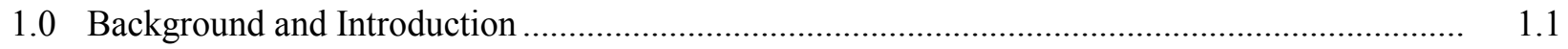

$2.0 \quad$ Barrier Emplacement Performance ................................................................................. 2.1

3.0 Strontium-90 Treatment Performance .........................................................................

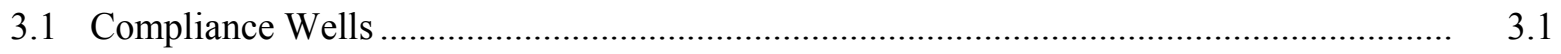

3.2 Pilot Test Site Monitoring Wells............................................................................ 3.4

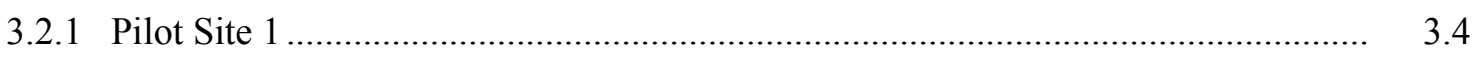

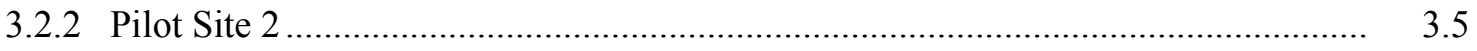

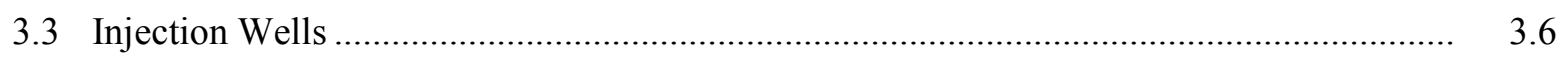

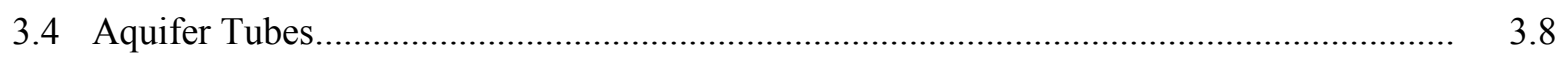

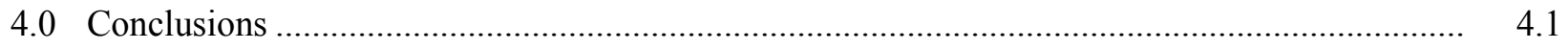

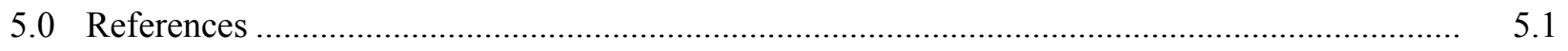

Appendix A: Barrier Performance: Compliance Wells_-8/1/08 through 10/31/10 ......................... A.1

Appendix B: Barrier Performance: Injection Wells—8/1/08 through 10/31/10 .............................. B.1

B.1. Fully Screened Hanford-Ringold Wells..................................................................... B. 2

B.2. Hanford-Only Treatment Wells .......................................................................... B.. B

B.3. Ringold-Only Treatment Wells............................................................................... B.7

Appendix C: Barrier Performance: Pilot Site Wells—8/1/08 through 10/31/10 .............................. C.1

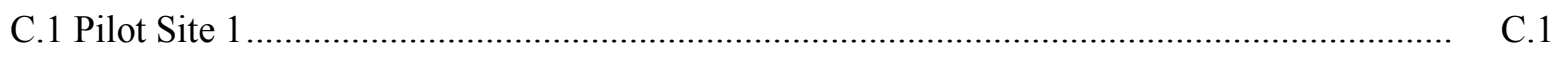

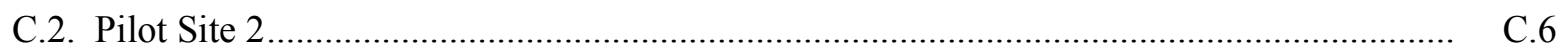

Appendix D: Barrier Performance: Aquifer Tubes—8/1/08 through 10/31/10 …........................... D.1 


\section{Figures}

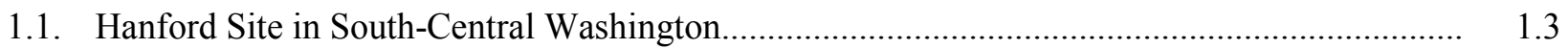

1.2. ${ }^{90}$ Sr Distributions Along 100-N Area Shoreline, September 2006 ........................................ 1.4

1.3. Map of the Injection and Primary Monitoring Wells for the PRB Site .................................... 1.5

1.4. Map of Groundwater Monitoring Locations near the PRB Site ............................................. 1.5

1.5. Well Locations at Pilot Test Sites .................................................................................... 1.6

2.1. PRB Injection and Compliance Wells............................................................................. 2.2

3.1. Recent ${ }^{90} \mathrm{Sr}$ Concentrations Measured in Compliance Monitoring Wells, and Percent Reduction from the Maximum Baseline Concentration ........................................................ 3.3

3.2. Observed ${ }^{90} \mathrm{Sr}$ Concentrations Shown in Relation to Baseline (pre-treatment) Range............... 3.4

3.3. Concentrations of ${ }^{90} \mathrm{Sr}$ Measured PRB Injection Wells Where Rebound Was Observed ........... 3.7

3.4. Concentrations of ${ }^{90} \mathrm{Sr}$ Measured at Aquifer Tube Locations Adjacent to the PRB.................. 3.8

\section{Tables}

2.1. Operational Performance Summary Assessing Compliance with Injection Design Criteria ...... $\quad 2.1$

3.1. Percent Reduction in ${ }^{90} \mathrm{Sr}$ Concentration Relative to Estimated Baseline Conditions at Compliance Monitoring Wells ........................................................................................ 3.2

3.2. Percent Change in Calcium Concentration Relative to Baseline Concentrations ..................... 3.2

3.3. Percent Reduction in ${ }^{90} \mathrm{Sr}$ Concentration Relative to Estimated Baseline Conditions at Pilot Site 1 Monitoring Wells

3.4. Percent Reduction in ${ }^{90} \mathrm{Sr}$ Concentration Relative to Estimated Baseline Conditions at Pilot Site 2 Monitoring Wells

3.5. Percent Reduction in ${ }^{90} \mathrm{Sr}$ Concentration Relative to Estimated Baseline Conditions at Injection Wells 


\subsection{Background and Introduction}

The Hanford Site is a U.S. Department of Energy (DOE)-owned site located in southeastern Washington State near Richland, Washington (Figure 1.1). The 100-N Area is located along the Columbia River and includes the 100-N Reactor, a DOE nuclear reactor previously used for plutonium production. Liquid effluents from reactor operations were historically discharged to ground, resulting in contaminated groundwater discharge to the Columbia River. Detailed site operational and characterization information can be found in a number of previously published reports (DOE/RL 2004, DOE/RL 2006, Mendoza et al. 2007, Szecsody et al. 2007, Williams et al. 2008, Szecsody et al. 2009, Szecsody et al. 2010, Vermeul et al. 2010).

Efforts to reduce the flux of strontium-90 $\left({ }^{90} \mathrm{Sr}\right)$ to the Columbia River from past-practice, liquid waste, disposal sites have been underway since the early 1990s in the 100-N Area. Terminating all liquid discharges to the ground in 1993 was a major step toward meeting this goal. However, ${ }^{90} \mathrm{Sr}$ adsorbed on aquifer solids beneath the liquid waste disposal sites and extending beneath the near-shore riverbed remains a continuing source to groundwater and the Columbia River. The initial remedial alternative selected, which was a pump-and-treat system, was unable to meet remedial objectives, and it was recognized that it was unlikely to be an effective long-term solution because of the geochemical characteristics of ${ }^{90} \mathrm{Sr}$. Accordingly, the first Comprehensive Environmental Response, Compensation, and Liability Act of 1980 (CERCLA 1980) 5-year review re-emphasized the need to pursue alternative methods to reduce impacts on the Columbia River.

After evaluating potential ${ }^{90} \mathrm{Sr}$ treatment technologies and their applicability under 100-NR-2 hydrogeologic conditions and presenting the Evaluation of ${ }^{90} \mathrm{Sr}$ Treatment Technologies for the $100 \mathrm{NR}-2$ Groundwater Operable Unit ${ }^{(\mathrm{a})}$ at the December 8, 2004, public meeting, DOE, Fluor Hanford, Inc. (now CH2M Hill Plateau Remediation Company [CHPRC]), Pacific Northwest National Laboratory, and the Washington State Department of Ecology agreed that the long-term strategy for groundwater remediation at the 100-N Area should include apatite sequestration as the primary treatment technology. In July 2005, aqueous injection (i.e., introducing apatite-forming chemicals to the subsurface through standard injection wells) was endorsed as the interim remedy and was selected for treatability testing. After the apatite treatment technology was selected, site-specific characterization data were used to select the most appropriate location for an initial Permeable Reactive Barrier (PRB) emplacement. The PRB site was chosen such that it overlaps the centerline of the ${ }^{90} \mathrm{Sr}$ plume, as close to the Columbia River as possible (Figure 1.2). Therefore, the locations of wells and aquifer tubes used for monitoring barrier performance are very close to the Columbia River (Figure 1.3 through Figure 1.5).

Between May 2006 and July 2008, apatite-forming chemicals were injected multiple times to form the PRB. These operations included pilot tests at two separate locations and the emplacement of a 300-ft barrier section using a low-concentration apatite formulation (Williams et al. 2008). Following this initial low-concentration treatment, there were two pilot tests, and the full 300-ft barrier section was treated with a high concentration formulation (Vermeul et al. 2010). Because these emplacement operations have been previously reported in the documents cited above, they will not be comprehensively addressed in this report. However, it is important to note that the design criteria established to determine barrier

(a) Fluor Hanford, Inc. and CH2M Hill Hanford Group. 2004. Evaluation of Strontium-90 Treatment Technologies for the 100-NR-2 Groundwater Operable Unit. Letter Report available online at http://www.washingtonclosure.com/projects/endstate/risk_library.html\#narea. 
emplacement performance were only met for 8 of the 16 injection wells. Primary design criteria not met during these initial injections included 1) a limited vertical extent of treatment within the Hanford formation, resulting from low river stage during emplacement operations and 2) a limited lateral extent of treatment within the Ringold Formation, resulting from amendment loss to the overlying, higher permeability Hanford formation and an associated amendment volume shortfall (Vermeul et al. 2010).

This report was prepared to provide an update on PRB performance 2 years after initial barrier emplacement operations, providing an additional year of performance monitoring data relative to what has been previously reported. The remainder of this report includes a summary of the PRB emplacement operational performance (Section 2.0) and a discussion of ${ }^{90} \mathrm{Sr}$ treatment performance based on aqueous monitoring data collected through October 2010 (Section 3.0). Conclusions are summarized in Section 4.0, and cited references are listed in Section 5.0. Appendices A-D contain monitoring results for samples collected between 8/1/08 and 10/31/10. 


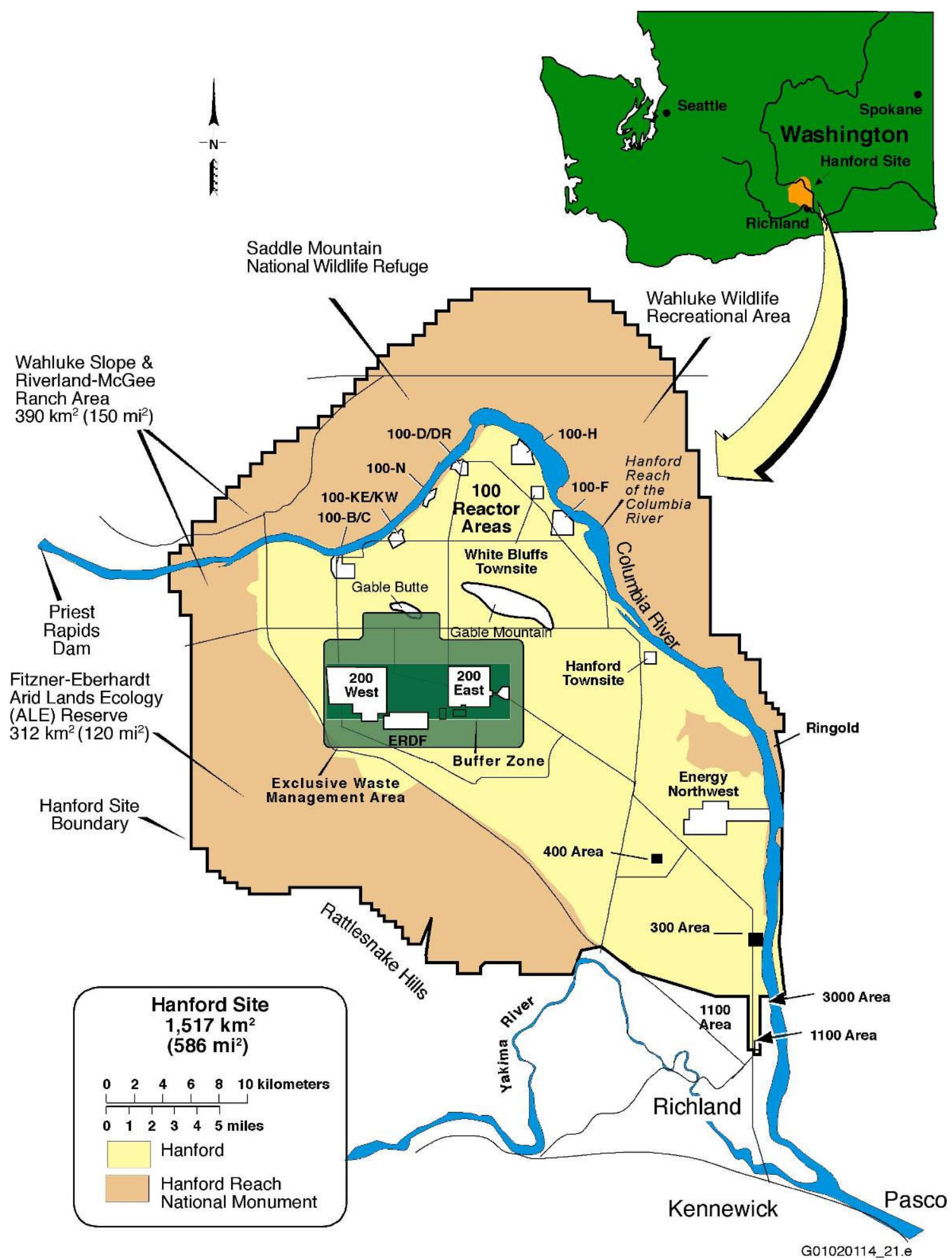

Figure 1.1. Hanford Site in South-Central Washington. The 100-N Area is located on the northern portion of the site along the Columbia River. 


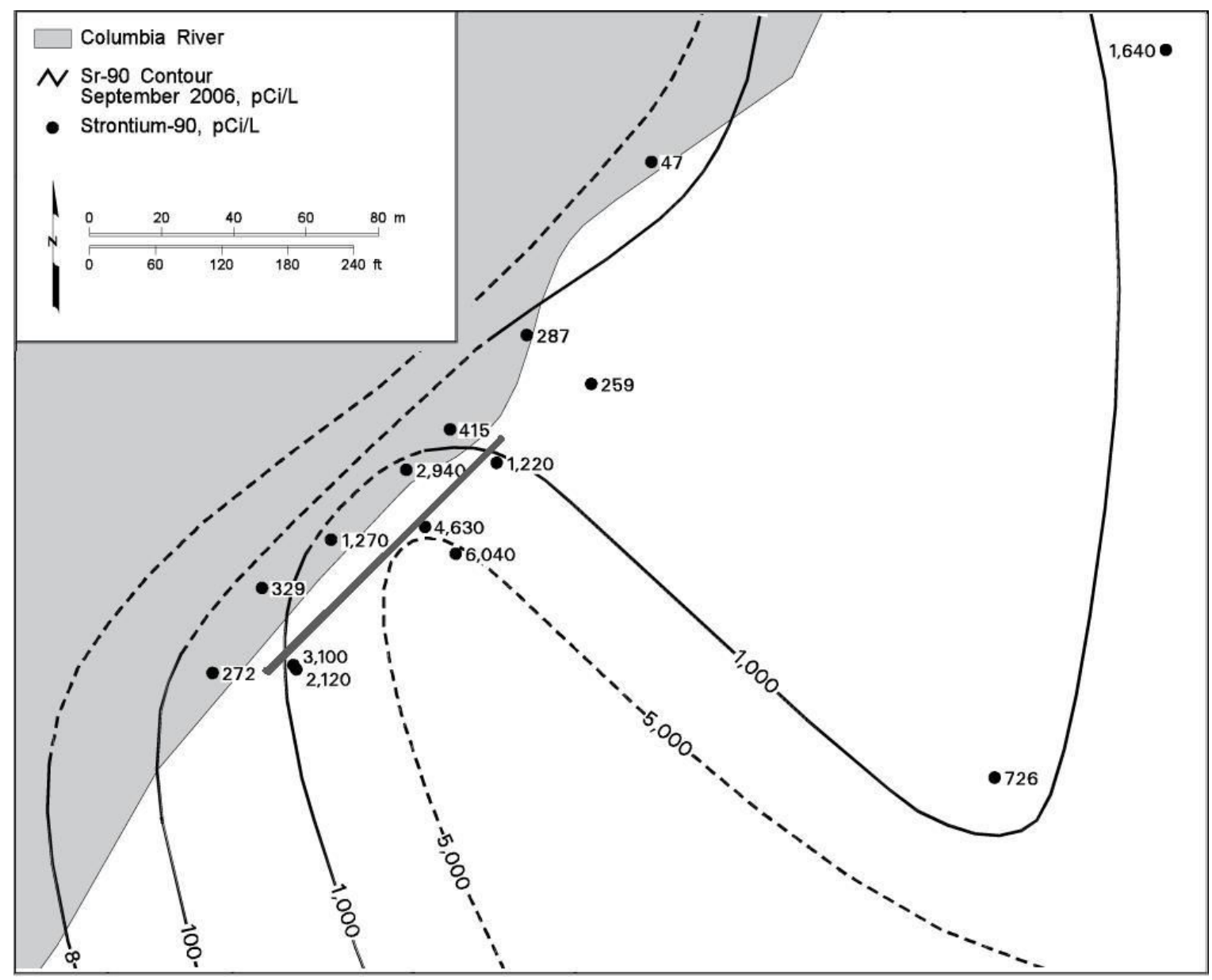

Figure 1.2. ${ }^{90}$ Sr Distributions Along 100-N Area Shoreline, September 2006 (from Hartman et al. 2007). PRB location shown in dark grey. 


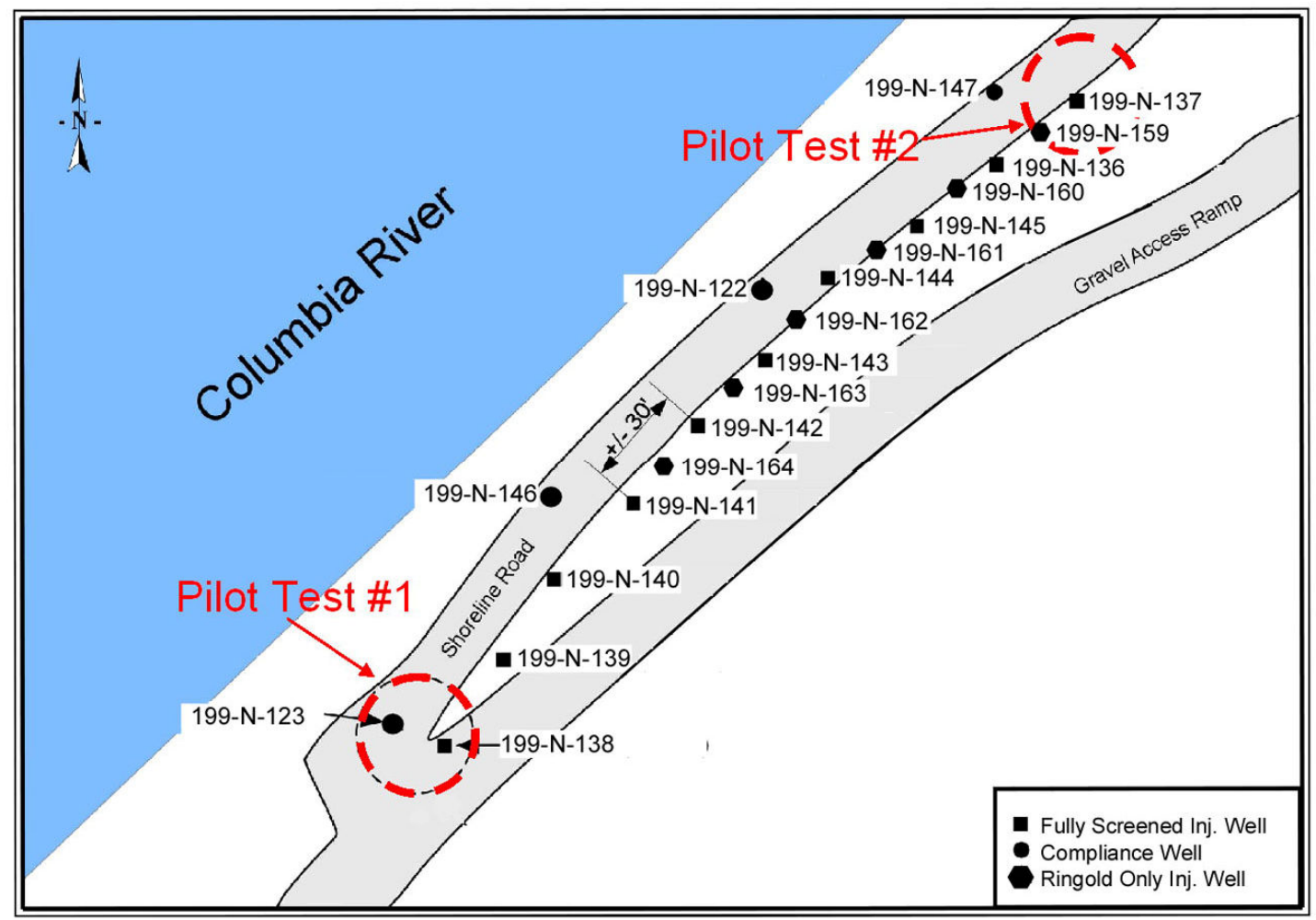

Figure 1.3. Map of the Injection and Primary Monitoring Wells for the PRB Site

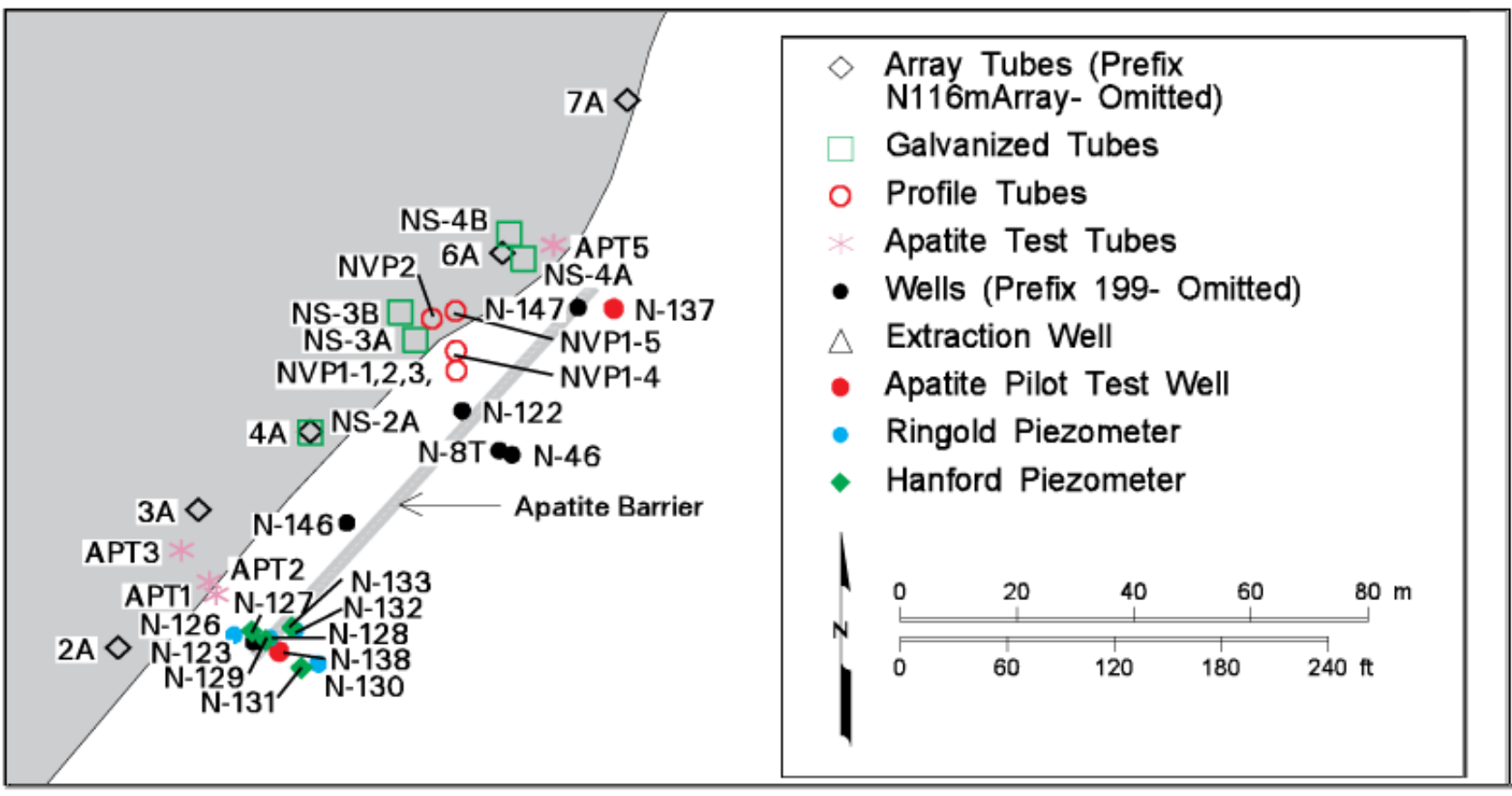

Figure 1.4. Map of Groundwater Monitoring Locations near the PRB Site 
Columbia River Boundary

(variable depending on river stage)
- $A P T-3(r=\sim 70 \mathrm{ft})$

- APT-2 $(r=\sim 50 \mathrm{ft})$

- APT-1 $(r=\sim 40 \mathrm{ft})$
"Note: Aquifer tube locations

not to scale. Screens
set at $116 \mathrm{~m}$ elevation

- NS4A ( $r=\sim 58 \mathrm{ft})$

○० APT-5 and $-5 \mathrm{~S}(\mathrm{r}=\sim 40 \mathrm{ft})$
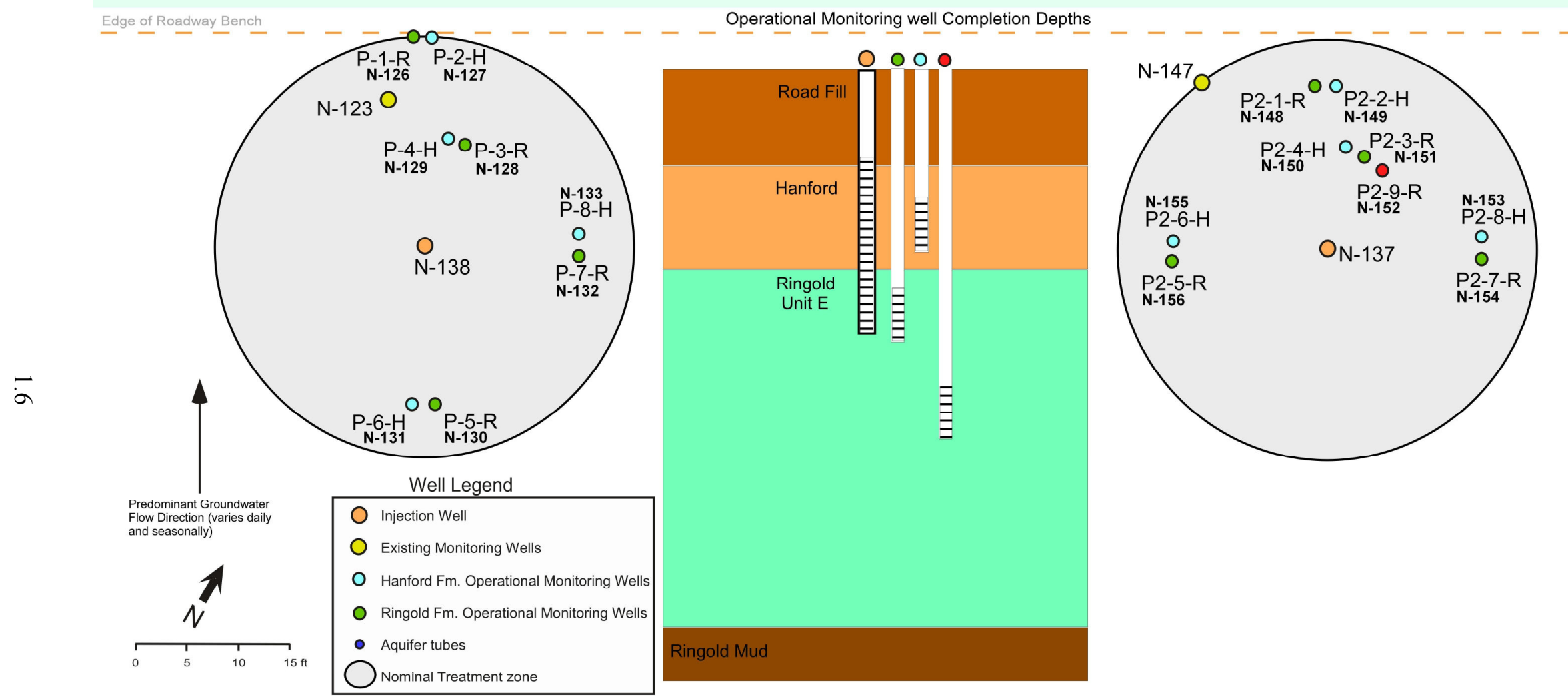

Figure 1.5. Well Locations at Pilot Test Sites 


\subsection{Barrier Emplacement Performance}

This section provides a brief description of observed barrier emplacement performance during the June-July 2008 apatite amendment injection operations. A detailed description of these barrier emplacement operations and their compliance with specified injection design criteria are presented in Vermeul et al. (2010). The apatite PRB was emplaced by means of multiple treatment injections along the length of the barrier. Injection design criteria were not fully met (or the data were insufficient to determine if design criteria were met) at half of the injection well locations (8 out of 16, see Table 2.1). Failure to meet design criteria resulted from insufficient distribution of chemical mass both laterally and vertically. Although injection design criteria were not fully met along the full barrier length, aqueous performance assessment, monitoring data collected through the end of FY09 indicated good barrier performance, even at locations where design criteria were not fully met. Section 3 provides an update to this assessment, based on performance monitoring data collected through the end of FY10.

The locations of wells where injection design criteria were and were not fully met are shown in Figure 2.1. Given the number of wells that did not fully meet injection design criteria, their locations, which are spread throughout the full barrier length, and potential end effects associated with the upstream and downstream-most compliance wells (Figure 2.1), it is difficult to provide a quantitative assessment of the relationship between barrier emplacement performance and ${ }^{90} \mathrm{Sr}$ treatment performance. It should be noted that well 199-N-122, which is located immediately downgradient of two wells that met injection design criteria, showed the highest percent ${ }^{90} \mathrm{Sr}$ reduction of the four compliance monitoring wells by the end of FY10 (results presented in Section 3). This observation in and of itself does not constitute definitive evidence of a relationship between barrier emplacement performance and ${ }^{90} \mathrm{Sr}$ treatment performance, although a direct relationship would be expected.

Table 2.1. Operational Performance Summary Assessing Compliance with Injection Design Criteria. Well locations where design criteria were not fully met are highlighted in green (from Vermeul et al. 2010).

\begin{tabular}{|c|c|c|c|c|c|}
\hline \multirow[b]{2}{*}{ Injection Well } & \multicolumn{5}{|c|}{ Compliance with Injection Design Criteria } \\
\hline & $\begin{array}{l}\text { Injection } \\
\text { Volume }\end{array}$ & $\begin{array}{c}\text { Injection } \\
\text { Mass }\end{array}$ & $\begin{array}{l}\text { Radial Extent of } \\
\text { Treatment - Hanford }\end{array}$ & $\begin{array}{l}\text { Radial Extent of } \\
\text { Treatment - Ringold }\end{array}$ & $\begin{array}{l}\text { Vertical Extent of } \\
\text { Hanford Treated }^{(\mathrm{a})}\end{array}$ \\
\hline N-137 & Yes & Yes & Yes & -- & $103 \%$ \\
\hline N-159 & Yes & Yes & -- & Yes & -- \\
\hline $\mathrm{N}-136$ & Yes & Yes & Yes & -- & $16 \%$ \\
\hline $\mathrm{N}-160$ & Yes & Yes & -- & Yes & -- \\
\hline $\mathrm{N}-145$ & Yes & Yes & Yes & -- & $86 \%$ \\
\hline N-161 & Yes & Yes & -- & No & -- \\
\hline $\mathrm{N}-144$ & Yes & Yes & Inconclusive & -- & $14 \%$ \\
\hline $\mathrm{N}-162$ & Yes & Yes & -- & Yes & -- \\
\hline N-143 & Yes & Yes & Yes & -- & $75 \%$ \\
\hline N-163 & Yes & Yes & -- & No & -- \\
\hline N-142 & Yes & Yes & Inconclusive & -- & $16 \%$ \\
\hline N-164 & No & No & -- & Inconclusive & -- \\
\hline N-141 & Yes & Yes & No & No & $86 \%$ \\
\hline N-140 & Yes & Yes & Inconclusive & Inconclusive & $14 \%$ \\
\hline N-139 & Yes & Yes & Yes & Yes & $75 \%$ \\
\hline $\mathrm{N}-138$ & Yes & Yes & Yes & Yes & $103 \%$ \\
\hline
\end{tabular}

(a) Assumes Hanford formation extends between 117.5 and $120 \mathrm{~m}$ elevation. Average river stage over injection period and 7-day reaction period used. 


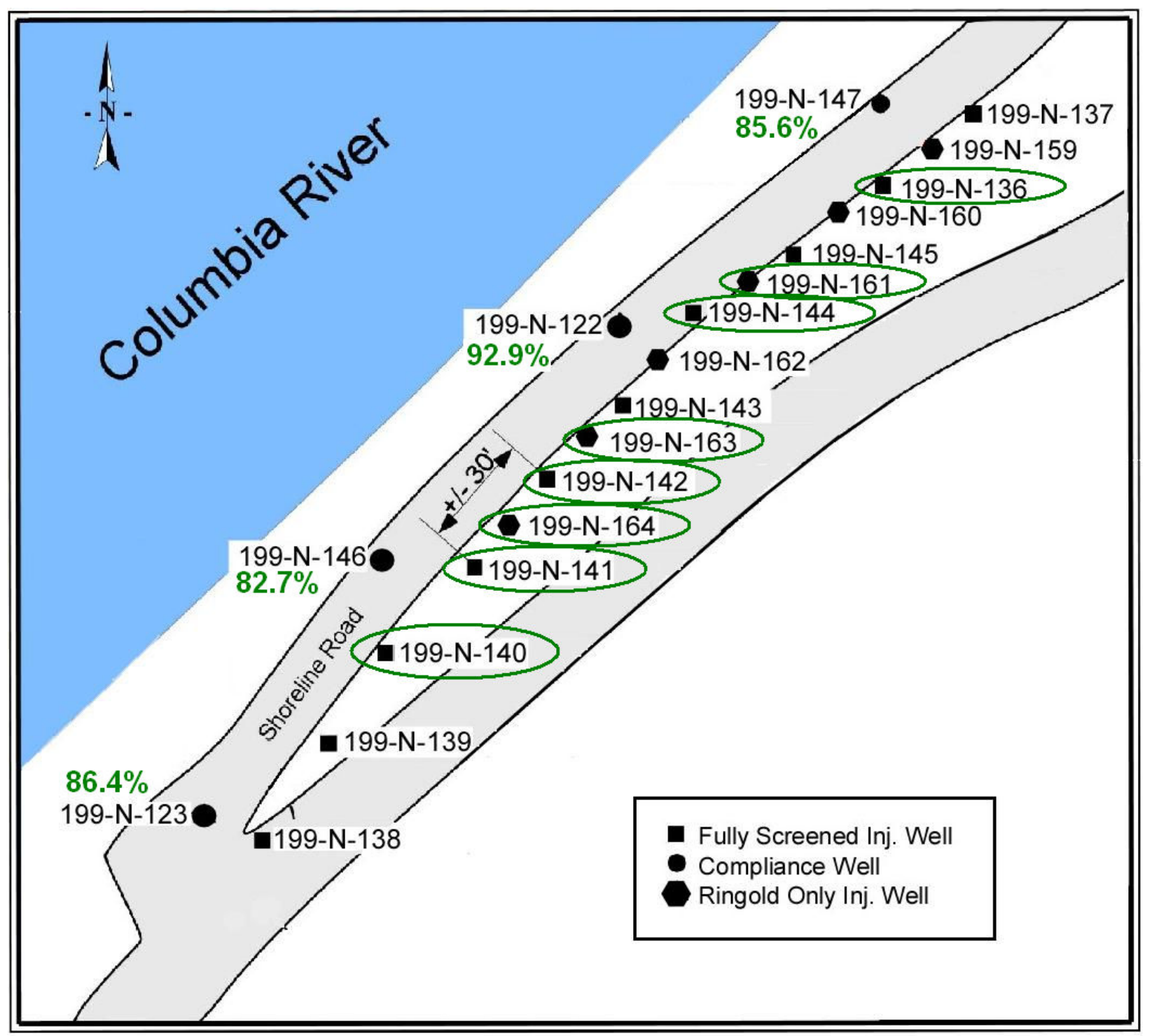

Figure 2.1. PRB Injection and Compliance Wells. Green circles indicate wells where design criteria were not met during emplacement operations. Green numbers are the percent reduction in ${ }^{90} \mathrm{Sr}$ concentration in 2010 relative to the maximum baseline concentration. 


\subsection{Strontium-90 Treatment Performance}

The initial phase of PRB emplacement operations ended in July 2008; most of the PRB injection and monitoring wells were sampled in August 2010, providing 2 years of monitoring results for barrier performance assessment. The remedial objective, as stated in the Strontium-90 Treatability Test Plan for 100-NR-2 Groundwater Operable Unit (DOE/RL 2006), is a $>90 \%$ reduction in ${ }^{90} \mathrm{Sr}$ concentration in performance/compliance monitoring wells and/or injection wells. Concentrations of ${ }^{90} \mathrm{Sr}$ measured in the most recently collected groundwater samples were compared to the baseline concentration range and are presented in the sections below. In summary, ${ }^{90} \mathrm{Sr}$ concentrations remained substantially below pretreatment levels for the 2-year monitoring period (Appendix A-C). Concentrations did generally trend upward during the second year of monitoring, but additional monitoring is needed to confirm this trend. As discussed below, some variations in ${ }^{90} \mathrm{Sr}$ concentration are expected in the short term following injection operations (e.g., from changes in groundwater concentrations entering the treatment zone and/or re-equilibration of geochemical perturbations associated with the injection process). Longer term monitoring data are needed to evaluate the relative importance of the observed trend and provide a more definitive assessment of expected long-term barrier performance.

\subsection{Compliance Wells}

Following completion of the initial phase of PRB emplacement operations in July $2008,{ }^{90} \mathrm{Sr}$ concentrations measured at the compliance monitoring wells trended downward for about 1 year. However, between August 2009 and October 2010, this trend has reversed, and small increases (relative to baseline maximum concentrations) in ${ }^{90} \mathrm{Sr}$ concentration have been observed (Table 3.1, Figure 3.1). As of August 2010, only one of the four compliance monitoring wells showed a greater than $90 \%$ reduction in ${ }^{90} \mathrm{Sr}$ concentration relative to the maximum baseline concentration, while the other three compliance wells all showed greater than $80 \%$ reduction. It should be noted that two of the compliance wells are located near the ends of the barrier and may be impacted by groundwater that does not pass directly through the barrier. The cause of the observed ${ }^{90} \mathrm{Sr}$ concentration increases in 2010 in the compliance monitoring wells is not known, although small increases were not unexpected. Low aqueous

${ }^{90} \mathrm{Sr}$ concentrations were previously reported as resulting from a combination of 1) incorporation of ${ }^{90} \mathrm{Sr}$ into apatite precipitates and 2) advection of ${ }^{90} \mathrm{Sr}$ (and $\mathrm{Sr}$, and $\mathrm{Ca}$ ) out of the injection zone by the high ionic strength (primarily $\mathrm{Na}+$ ) injection solution. Therefore, one plausible explanation is that ${ }^{90} \mathrm{Sr}$ (and $\mathrm{Sr}$ and $\mathrm{Ca}$ ) entering the treatment zone from upgradient results in concentrations increasing as the system reaches natural sediment/water equilibrium conditions. It is also possible that the observed ${ }^{90} \mathrm{Sr}$ increase is associated with untreated (or partially treated) sediments within the zone between the PRB and the Columbia River; this zone was never intended to receive full treatment. Given the extent of treatment and the dynamic nature of river stage and groundwater flow in this near-shore environment, dissolution of contaminant ${ }^{90} \mathrm{Sr}$ from this zone must be considered in the assessment.

It is unclear whether the observed increase in aqueous ${ }^{90} \mathrm{Sr}$ concentration is a transient effect or part of a long-term trend, but solid phase sampling to measure the adsorbed and incorporated ${ }^{90} \mathrm{Sr}$ could be used to quantify this effect. It is not unexpected that ${ }^{90} \mathrm{Sr}$ concentrations would increase to some extent as the effects of ${ }^{90} \mathrm{Sr}$ desorption during treatment operations are reversed through transport of ${ }^{90} \mathrm{Sr}$ contaminated groundwater into the treatment zone. However, an evaluation of aqueous calcium concentrations in the downgradient compliance monitoring wells (Table 3.2) shows that calcium concentrations have 
rebounded to as much as $57 \%$ of the baseline concentration while the percent reduction in ${ }^{90} \mathrm{Sr}$ concentration has remained significantly higher. This comparison demonstrates the effects of ${ }^{90} \mathrm{Sr}$ uptake by apatite on aqueous contaminant concentrations (i.e., the observed reduction in ${ }^{90} \mathrm{Sr}$ concentrations cannot be explained alone by contaminant desorption during treatment).

Table 3.1. Percent Reduction in ${ }^{90} \mathrm{Sr}$ Concentration Relative to Estimated Baseline Conditions at Compliance Monitoring Wells

\begin{tabular}{|c|c|c|c|c|c|c|c|}
\hline \multirow[b]{2}{*}{ Well Name } & \multicolumn{4}{|c|}{${ }^{90} \mathrm{Sr}$ Concentration $(\mathrm{pCi} / \mathrm{L})$} & \multirow{2}{*}{$\begin{array}{c}\text { Percent Increase } \\
\text { in }{ }^{90} \mathrm{Sr} \\
\text { Concentration } \\
2009 \text { to } 2010 \\
\end{array}$} & \multicolumn{2}{|c|}{$\begin{array}{l}\text { Percent Reduction in } \\
{ }_{90}^{90} \mathrm{Sr} \text { Concentration } \\
(2010 \text { measurement })\end{array}$} \\
\hline & $\begin{array}{c}\text { Min } \\
\text { Baseline }\end{array}$ & $\begin{array}{c}\text { Max } \\
\text { Baseline }\end{array}$ & $\begin{array}{c}8 / 13 / 09 \\
\text { Result } \\
\end{array}$ & $\begin{array}{c}8 / 15 / 10 \\
\text { Result }\end{array}$ & & $\begin{array}{c}\text { Min } \\
\text { Baseline }\end{array}$ & $\begin{array}{c}\text { Max } \\
\text { Baseline }\end{array}$ \\
\hline $199-\mathrm{N}-122$ & 657 & 4630 & 100 & 330 & $230 \%$ & $50 \%$ & $93 \%$ \\
\hline $199-\mathrm{N}-123$ & 689 & 1180 & 70.0 & 160 & $129 \%$ & $77 \%$ & $86 \%$ \\
\hline $199-\mathrm{N}-146$ & 318 & 985 & 85.0 & 170 & $100 \%$ & $47 \%$ & $83 \%$ \\
\hline $199-\mathrm{N}-147$ & 522 & 1842 & 65.0 & 200 & $208 \%$ & $62 \%$ & $89 \%$ \\
\hline
\end{tabular}

Table 3.2. Percent Change in Calcium Concentration Relative to Baseline Concentrations. Baseline Determined as the Average Ca Concentration Measured in Performance Wells Before Chemical Injections.

\begin{tabular}{lccc}
\hline Well Name & $\begin{array}{c}\text { Baseline Calcium } \\
\text { concentration }(\mathrm{mg} / \mathrm{L})\end{array}$ & $\begin{array}{c}\text { Calcium concentration } \\
\text { on } 8 / 15 / 10(\mathrm{mg} / \mathrm{L})\end{array}$ & \% of Baseline \\
\hline $199-\mathrm{N}-122$ & 22.1 & 12.5 & 57 \\
$199-\mathrm{N}-123$ & 22.1 & 11.6 & 52 \\
$199-\mathrm{N}-146$ & 22.1 & 4.5 & 20 \\
$199-\mathrm{N}-147$ & 22.1 & 7.7 & 35 \\
\hline
\end{tabular}

Although ${ }^{90} \mathrm{Sr}$ concentrations appear to have trended upward to some extent over the past year of monitoring, aqueous concentrations are still being maintained at levels well below their pre-treatment maximum values (Figure 3.2; results for all compliance wells included in Appendix A). Longer term performance monitoring is necessary to adequately describe temporal trends and provide a thorough evaluation of PRB performance. 

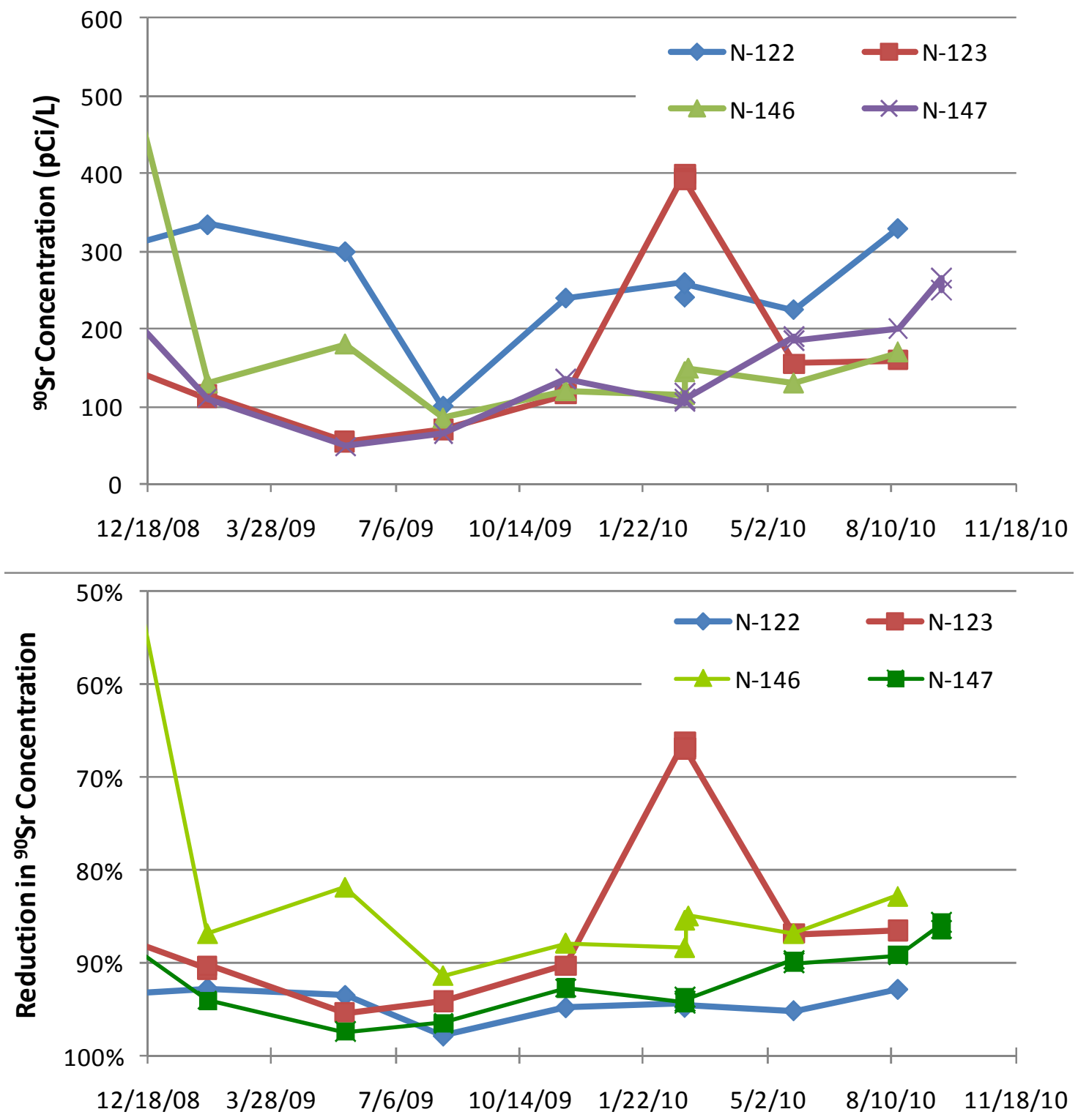

Figure 3.1. Recent ${ }^{90} \mathrm{Sr}$ Concentrations Measured in Compliance Monitoring Wells, and Percent Reduction from the Maximum Baseline Concentration. Longer temporal plots included in Appendices. 


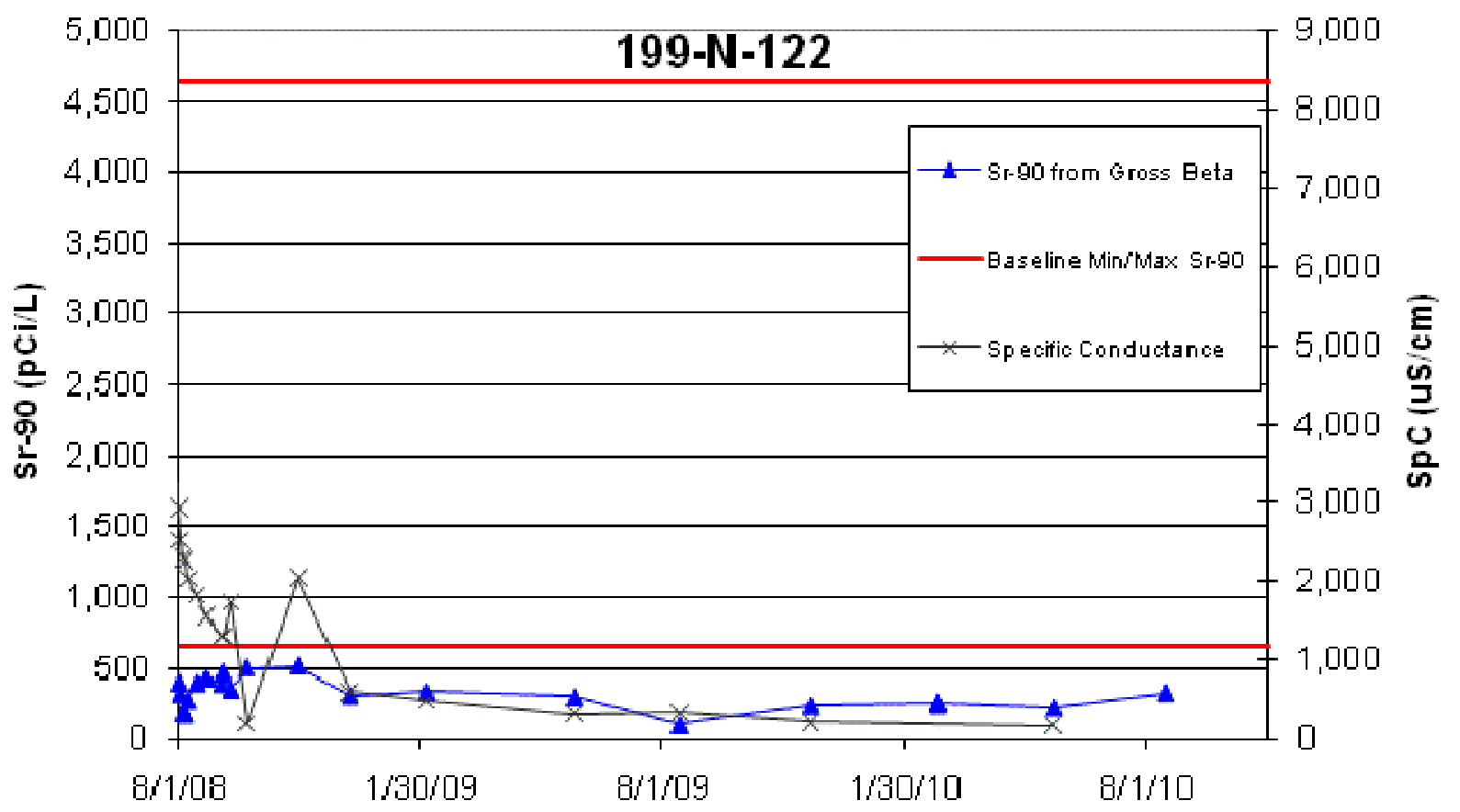

Figure 3.2. Observed ${ }^{90} \mathrm{Sr}$ Concentrations Shown in Relation to Baseline (pre-treatment) Range

\subsection{Pilot Test Site Monitoring Wells}

\subsubsection{Pilot Site 1}

Although sample collection constraints limited the number of performance assessment samples collected at the upstream, pilot test site location (i.e., continuous quarterly measurements are only available at two locations, both Ringold Formation monitoring wells), monitoring well data for the pilot test sites are beneficial to the assessment because they represent the only available measure of treatment performance that 1) is located at some radial distance from the point of injection but still located within the targeted treatment zone (i.e., compliance monitoring wells are located on the downgradient edge of the treatment zone) and 2) is not an injection well, which can result in an overly positive assessment of performance because of the high levels of treatment capacity emplaced in the immediate vicinity of the well. At the pilot site 1 location, injection design criteria were generally met (see well 199-N-138 in Table 2.1), which is consistent with the observed aqueous monitoring results. The monitoring wells at this pilot test site location, with the exception of well 199-N-130, which is on the upgradient edge of the treatment zone and received only marginal treatment during injection operations, have generally maintained low ${ }^{90} \mathrm{Sr}$ concentrations since PRB emplacement (Table 3.3). Excluding the injection well and the up-gradient wells, the average reduction in ${ }^{90} \mathrm{Sr}$ concentration relative to the maximum baseline is $88 \%$. While some slight rebound in ${ }^{90} \mathrm{Sr}$ concentrations was observed between 2009 and 2010, at most of the wells within pilot site $1,{ }^{90} \mathrm{Sr}$ concentrations were similar or decreased during this time. Unfortunately, only one Hanford formation well was sampled in 2010, so this comparison is limited to the Ringold Formation monitoring wells. 
Table 3.3. Percent Reduction in ${ }^{90} \mathrm{Sr}$ Concentration Relative to Estimated Baseline Conditions at Pilot Site 1 Monitoring Wells

\begin{tabular}{|c|c|c|c|c|c|c|c|}
\hline \multirow[b]{2}{*}{ Well Name } & \multicolumn{4}{|c|}{${ }^{90} \mathrm{Sr}$ Concentration $(\mathrm{pCi} / \mathrm{L})$} & \multirow{2}{*}{$\begin{array}{c}\text { Percent Increase } \\
\text { in }{ }^{90} \mathrm{Sr} \\
\text { Concentration } \\
2009 \text { to } 2010\end{array}$} & \multicolumn{2}{|c|}{$\begin{array}{l}\text { Percent Reduction in } \\
{ }^{90} \mathrm{Sr} \text { Concentration } \\
{ }^{(\mathrm{c})}\end{array}$} \\
\hline & $\begin{array}{c}\text { Min } \\
\text { baseline }\end{array}$ & $\begin{array}{c}\text { Max } \\
\text { baseline }\end{array}$ & $\begin{array}{l}8 / 13 / 09 \\
\text { Result }\end{array}$ & $\begin{array}{l}8 / 15 / 10 \\
\text { Result }\end{array}$ & & $\begin{array}{c}\text { Min } \\
\text { Baseline }\end{array}$ & $\begin{array}{c}\text { Max } \\
\text { Baseline }\end{array}$ \\
\hline $199-\mathrm{N}-123^{(\mathrm{a})}$ & 689 & 1180 & 70.0 & 160 & $129 \%$ & $77 \%$ & $86 \%$ \\
\hline $199-\mathrm{N}-138^{(\mathrm{b}}$ & 602 & 1103 & NS & 19.5 & NA & $97 \%$ & $98 \%$ \\
\hline 199-N-126(P-1-R) & 602 & 1103 & $160 *$ & 120 & $-25 \%$ & $80 \%$ & $89 \%$ \\
\hline 199-N-127(P-2-H) & 602 & 1103 & NS & NS & NA & NS & NS \\
\hline $199-\mathrm{N}-128(\mathrm{P}-3-\mathrm{R})$ & 602 & 1103 & 31.5 & 120 & $281 \%$ & $80 \%$ & $89 \%$ \\
\hline 199-N-129(P-4-H) & 602 & 1103 & $85.0^{* *}$ & NS & NA & $86 \%$ & $92 \%$ \\
\hline 199-N-130(P-5-R) & 602 & 1103 & $4200 *$ & 1400 & $-67 \%$ & -- & -- \\
\hline 199-N-131(P-6-H) & 602 & 1103 & NS & NS & NA & NS & NS \\
\hline 199-N-132(P-7-R) & 602 & 1103 & 205 & 305 & $49 \%$ & $49 \%$ & $72 \%$ \\
\hline 199-N-133(P-8-H) & 602 & 1103 & $100 * *$ & $115^{* * *}$ & $15 \%$ & $81 \%$ & $90 \%$ \\
\hline $\begin{array}{l}\text { (a) Compliance m } \\
\text { (b) Injection Well } \\
\text { (c) Based on last a } \\
-\mathrm{H}=\text { Hanford form } \\
\mathrm{NS} \text { - No Samples } \\
\text { * Sample collected } \\
\text { **Sample collectec } \\
\text { ***Sample collect }\end{array}$ & $\begin{array}{l}\text { nitoring } \mathrm{b} \\
\text { vailable } 20 \\
\text { ation, }-\mathrm{R}= \\
\text { ollected i } \\
\text { on } 2 / 4 / 09 \\
\text { on } 5 / 26 / 0 \\
\text { d on } 5 / 23\end{array}$ & $\begin{array}{l}\text { vell } \\
10 \text { measu } \\
\text { Ringold } 1 \\
\text { n } 2009 \text { or } \\
9 \\
10\end{array}$ & $\begin{array}{l}\text { ement } \\
\text { ormation } \\
010\end{array}$ & & & & \\
\hline
\end{tabular}

\subsubsection{Pilot Site 2}

Although injection design criteria were generally met at the downstream pilot test site location (see well 199-N-137 in Table 2.1), available monitoring results continue to show marginally better performance in the Hanford formation monitoring wells relative to those completed in the upper Ringold Formation. This is consistent with previously reported results (Williams et al. 2008) indicating preferential flow within the Hanford formation for fully screened wells over the downstream portion of the barrier as well as the need for increased treatment volumes in Ringold-only injection wells (Vermeul et al. 2010) to achieve wider radial treatment. However, with the exception of well 199-N-152, which is completed below the targeted treatment zone, and well 199-N-154, which is located on the downstream edge of the barrier where no overlap treatment from an adjacent injection well occurred, monitoring results indicate that this pilot test site location has generally maintained low ${ }^{90} \mathrm{Sr}$ concentrations since PRB emplacement (Table 3.4). Excluding the injection well and the peripheral Ringold wells discussed above, the average reduction in ${ }^{90} \mathrm{Sr}$ concentration relative to the maximum baseline is $91 \%$. As was observed at pilot site 1 , only a few of the pilot site 2 wells showed a rebound in ${ }^{90} \mathrm{Sr}$ concentrations from 2009 to 2010 comparable to that observed in the compliance monitoring wells. In addition, for those wells where an increase was observed, the 2010 concentrations were still at or near a $90 \%$ reduction relative to the maximum baseline concentrations. 
Table 3.4. Percent Reduction in ${ }^{90} \mathrm{Sr}$ Concentration Relative to Estimated Baseline Conditions at Pilot Site 2 Monitoring Wells

\begin{tabular}{|c|c|c|c|c|c|c|c|}
\hline \multirow[b]{2}{*}{ Well Name } & \multicolumn{4}{|c|}{${ }^{90} \mathrm{Sr}$ Concentration $(\mathrm{pCi} / \mathrm{L})$} & \multirow{2}{*}{$\begin{array}{l}\text { Percent Increase } \\
\text { in }{ }^{90} \mathrm{Sr} \\
\text { Concentration } \\
2009 \text { to } 2010\end{array}$} & \multicolumn{2}{|c|}{$\begin{array}{l}\text { Percent Reduction in } \\
{ }^{90} \mathrm{Sr} \text { Concentration }(\mathrm{d})\end{array}$} \\
\hline & $\underset{\text { baseline }}{\text { Min }}$ & $\underset{\text { Maseline }}{\text { Max }}$ & $\begin{array}{c}8 / 13 / 09 \\
\text { Result }\end{array}$ & $\begin{array}{l}8 / 15 / 10 \\
\text { Result }\end{array}$ & & $\begin{array}{c}\text { Min } \\
\text { Baseline }\end{array}$ & $\begin{array}{c}\text { Max } \\
\text { Baseline }\end{array}$ \\
\hline $199-\mathrm{N}-147^{(\mathrm{a})}$ & 522 & 1842 & 65 & 200 & $186 \%$ & $62 \%$ & $89 \%$ \\
\hline $199-\mathrm{N}-137^{(\mathrm{b})}$ & 487 & 1842 & $110^{*}$ & 245 & $123 \%$ & $50 \%$ & $87 \%$ \\
\hline 199-N-148(P2-1-R) & 487 & 1842 & 21.5 & 55.0 & $156 \%$ & $89 \%$ & $97 \%$ \\
\hline 199-N-149(P2-2-H) & 487 & 1842 & 120 & $110 * * *$ & $-8 \%$ & $77 \%$ & $94 \%$ \\
\hline $199-\mathrm{N}-150(\mathrm{P} 2-4-\mathrm{H})$ & 487 & 1842 & $60 * *$ & $155 * * *$ & $158 \%$ & $68 \%$ & $92 \%$ \\
\hline 199-N-151(P2-3-R) & 487 & 1842 & 95 & 195 & $105 \%$ & $60 \%$ & $89 \%$ \\
\hline $199-\mathrm{N}-152(\mathrm{P} 2-9-\mathrm{R})^{(\mathrm{c})}$ & 487 & 1842 & $800^{*}$ & 425 & $-47 \%$ & $13 \%$ & $77 \%$ \\
\hline 199-N-153(P2-8-H) & 487 & 1842 & NS & 160 & NA & $67 \%$ & $91 \%$ \\
\hline 199-N-154(P2-7-R) & 487 & 1842 & $1900 *$ & 1050 & $-45 \%$ & $-116 \%$ & $43 \%$ \\
\hline $199-\mathrm{N}-155(\mathrm{P} 2-6-\mathrm{H})$ & 487 & 1842 & 175 & $70.0 * * *$ & $-60 \%$ & $86 \%$ & $96 \%$ \\
\hline $199-\mathrm{N}-156(\mathrm{P} 2-5-\mathrm{R})$ & 487 & 1842 & 360 & 420 & $17 \%$ & $14 \%$ & $77 \%$ \\
\hline $\begin{array}{l}\text { (a) Compliance mon } \\
\text { (b) Injection Well } \\
\text { (c) Deep Ringold Fo } \\
\text { (d) Based on last av } \\
\text {-H = Hanford format } \\
\text { NS-No Samples Co } \\
\text { *Sample collected or } \\
\text { **Sample collected } \\
\text { ** Sample collected }\end{array}$ & $\begin{array}{l}\text { toring we } \\
\text { rmation W } \\
\text { ilable } 201 \\
\text { on, }-\mathrm{R}=\mathrm{R} \\
\text { llected in } 2 \\
2 / 5 / 09 \\
\text { n } 5 / 26 / 09 \\
\text { on } 5 / 23 / 10\end{array}$ & $\begin{array}{l}11 \\
\text { ell- below } \\
0 \text { measure } \\
\text { ingold Fo } \\
2009 \text { or } 20\end{array}$ & $\begin{array}{l}\text { target tre } \\
\text { nent } \\
\text { mation } \\
10\end{array}$ & ment zone & & & \\
\hline
\end{tabular}

\subsection{Injection Wells}

All injection wells have maintained low ${ }^{90} \mathrm{Sr}$ concentrations since barrier emplacement (Table 3.5). Several injection wells near the center of the barrier did appear to have a slight rebound in concentration, although the absolute concentrations were still very low (Figure 3.3). None of the other 12 barrier injection wells demonstrated any indication of a rebound effect, which is not unexpected given the relatively high treatment capacity that was likely emplaced in the immediate vicinity of the injection wells. These near-well sediments saw many pore volumes of apatite amendment solutions, providing a proportionally larger opportunity for both ${ }^{90} \mathrm{Sr}$ desorption and apatite formation. 
Table 3.5. Percent Reduction in ${ }^{90} \mathrm{Sr}$ Concentration Relative to Estimated Baseline Conditions at Injection Wells

\begin{tabular}{|c|c|c|c|c|c|c|c|}
\hline \multirow[b]{2}{*}{ Well Name } & \multicolumn{4}{|c|}{${ }^{90} \mathrm{Sr}$ Concentration $(\mathrm{pCi} / \mathrm{L})$} & \multirow{2}{*}{$\begin{array}{c}\text { Percent Increase } \\
\text { in }{ }^{90} \mathrm{Sr} \\
\text { Concentration } \\
2009 \text { to } 2010\end{array}$} & \multicolumn{2}{|c|}{$\begin{array}{l}\text { Percent Reduction in } \\
{ }^{90} \mathrm{Sr} \text { Concentration }{ }^{(\mathrm{c})}\end{array}$} \\
\hline & $\begin{array}{c}\text { Min } \\
\text { Baseline }\end{array}$ & $\begin{array}{c}\text { Max } \\
\text { Baseline }\end{array}$ & $\begin{array}{l}\text { 2/04/09 } \\
\text { Result }\end{array}$ & $\begin{array}{c}8 / 15 / 10 \\
\text { Result }\end{array}$ & & $\begin{array}{c}\text { Min } \\
\text { Baseline }\end{array}$ & $\begin{array}{c}\text { Max } \\
\text { Baseline }\end{array}$ \\
\hline $199-\mathrm{N}-138^{(\mathrm{a})}$ & 602 & 1103 & 20 & 20 & $0 \%$ & $97 \%$ & $98 \%$ \\
\hline $199-N-139^{(a)}$ & 278 & 829 & 4.6 & 6.0 & $30 \%$ & $98 \%$ & $99 \%$ \\
\hline $199-\mathrm{N}-140^{(\mathrm{a})}$ & 303 & 925 & 21 & 7.5 & $-64 \%$ & $98 \%$ & $99 \%$ \\
\hline $199-\mathrm{N}-141^{\text {(a) }}$ & 611 & 1624 & 28 & 95 & $240 \%$ & $84 \%$ & $94 \%$ \\
\hline $199-\mathrm{N}-164^{(\mathrm{b})}$ & 712 & 2262 & $11^{*}$ & 21 & $91 \%$ & $97 \%$ & $99 \%$ \\
\hline $199-\mathrm{N}-142^{(\mathrm{a})}$ & 812 & 2900 & $24^{*}$ & 14 & $-42 \%$ & $98 \%$ & $99 \%$ \\
\hline $199-N-163^{(b)}$ & 764 & 3445 & 14.5 & 65 & $348 \%$ & $91 \%$ & $98 \%$ \\
\hline $199-N-143^{(a)}$ & 715 & 3989 & 13 & 38 & $192 \%$ & $95 \%$ & $99 \%$ \\
\hline $199-\mathrm{N}-162^{(\mathrm{b})}$ & 1127 & 4148 & 48 & 45 & $-6 \%$ & $96 \%$ & $99 \%$ \\
\hline $199-\mathrm{N}-144^{(\mathrm{a})}$ & 1538 & 4306 & 24 & 140 & $483 \%$ & $91 \%$ & $97 \%$ \\
\hline $199-\mathrm{N}-161^{(\mathrm{b})}$ & 1268 & 4378 & 75 & 75 & $0 \%$ & $94 \%$ & $98 \%$ \\
\hline $199-\mathrm{N}-145^{(\mathrm{a})}$ & 997 & 4450 & $21 *$ & 26 & $24 \%$ & $97 \%$ & $99 \%$ \\
\hline $199-\mathrm{N}-160^{(\mathrm{b})}$ & 739 & 3292 & $50 *$ & 75 & $50 \%$ & $90 \%$ & $98 \%$ \\
\hline $199-\mathrm{N}-136^{(\mathrm{a})}$ & 480 & 2134 & 38 & 8.0 & $-79 \%$ & $98 \%$ & $100 \%$ \\
\hline $199-N-159^{(b)}$ & 484 & 1988 & 225 & 170 & $-24 \%$ & $65 \%$ & $91 \%$ \\
\hline $199-\mathrm{N}-137^{(\mathrm{a})}$ & 487 & 1842 & 110 & 245 & $123 \%$ & $50 \%$ & $87 \%$ \\
\hline
\end{tabular}

(a) Fully screened Injection Well

(b) Ringold only Injection Well

(c) Based on last available 2010 measurement

*Sample collected on 8/13/09

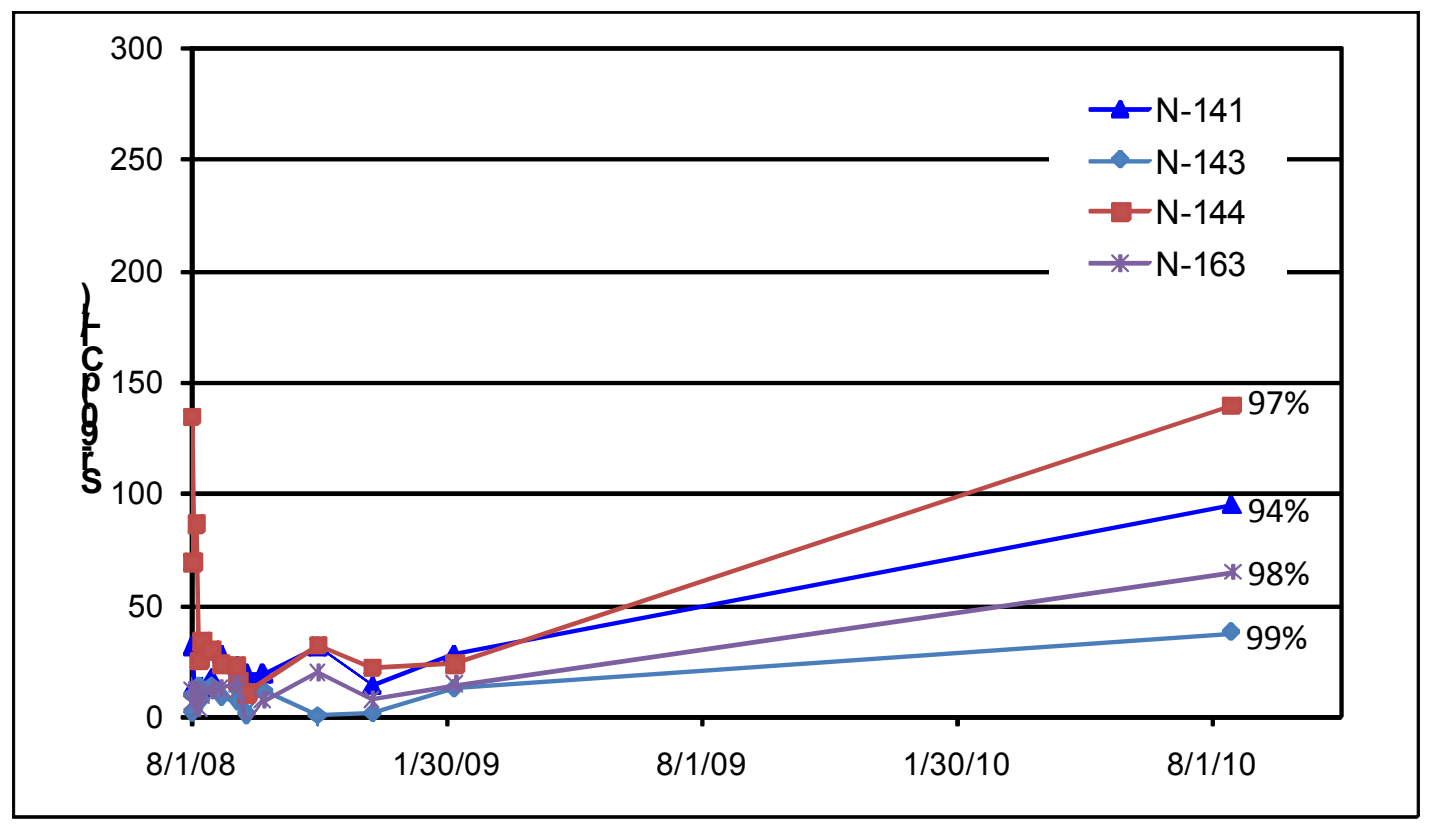

Figure 3.3. Concentrations of ${ }^{90} \mathrm{Sr}$ Measured PRB Injection Wells Where Rebound Was Observed. The percent reduction of ${ }^{90} \mathrm{Sr}$ relative to the maximum baseline concentration is shown for the August 2010 sample results. 


\subsection{Aquifer Tubes}

Aquifer tubes are small-diameter piezometers installed in the subsurface along the shoreline of the Columbia River. These monitoring locations allow for samples of mixed river and groundwater to be sampled within a few feet of the river. Unlike the groundwater wells in and around the PRB, substantial sampling of the aquifer tubes was conducted before PRB emplacement operations. These monitoring locations allow for a comparison of ${ }^{90} \mathrm{Sr}$ concentrations at the groundwater-river interface, which represents the primary receptor location, and the point of compliance for the tri-party agreement milestone. A comparison of ${ }^{90} \mathrm{Sr}$ concentrations measured in 2005 and 2006 (Mendoza et al. 2007) relative to concentrations measured in 2009 and 2010 indicates that the apatite PRB has, on average, resulted in a reduction in ${ }^{90} \mathrm{Sr}$ concentrations of approximately $50 \%$ along the most-contaminated portion of the barrier (Figure 3.4). This is a substantial decrease given that these monitoring locations are outside of the PRB treatment zone (but down-gradient), and that ${ }^{90} \mathrm{Sr}$ was known to be present in the sediments surrounding these aquifer tube locations before treatment (Mendoza et al. 2007).

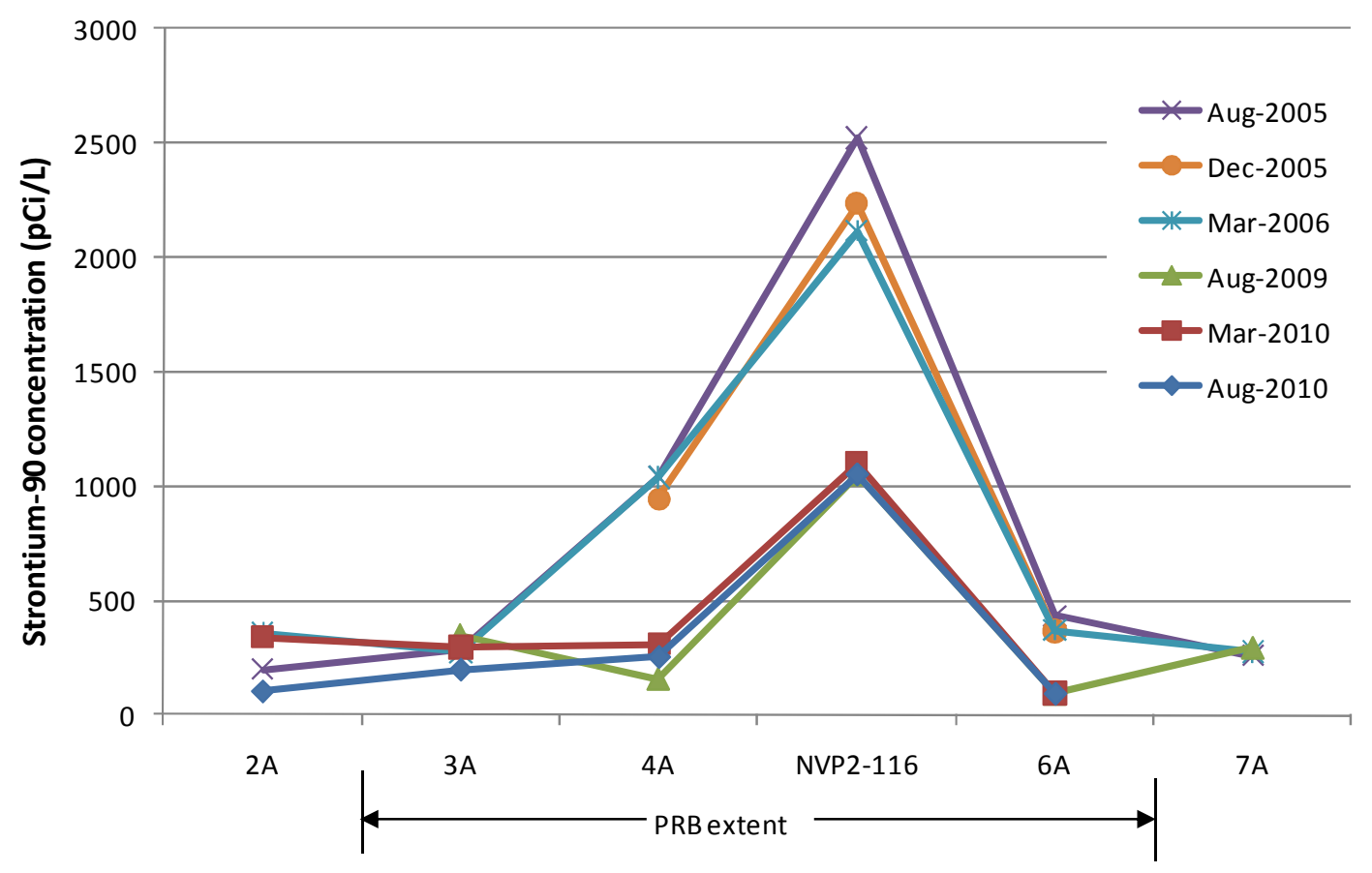

Figure 3.4. Concentrations of ${ }^{90} \mathrm{Sr}$ Measured at Aquifer Tube Locations Adjacent to the PRB 


\subsection{Conclusions}

During the PRB emplacement, temporary increases in ${ }^{90} \mathrm{Sr}$ concentrations were observed as ${ }^{90} \mathrm{Sr}$ was displaced from the sediment by the solution requiring a high-ionic-strength amendment. Following this temporary increase, concentrations of ${ }^{90} \mathrm{Sr}$ decreased through August 2009. However, since the fall of 2009 , the concentrations of ${ }^{90} \mathrm{Sr}$ measured in compliance monitoring wells as well as a select few injection wells have shown a small upward trend. Currently, the average reduction in ${ }^{90} \mathrm{Sr}$ concentrations at the four compliance monitoring locations is $88 \%$ relative to the high end of the baseline range and $57 \%$ relative to the low end of the baseline range. This indicates that the performance objective specified in the treatability test plan $\left(90 \%\right.$ reduction in ${ }^{90} \mathrm{Sr}$ concentration) is not currently being met. There are a number of possible explanations as to why concentrations have increased slightly since 2009; however, at this point, there are insufficient data to draw any definitive conclusions about the barrier's capability to meet performance objectives, or to make forecasts about future PRB performance. It is recommended that aqueous performance assessment monitoring be continued at the same frequency until the observed trend is better characterized. 



\subsection{References}

CERCLA-Comprehensive Environmental Response, Compensation, and Liability Act. 1980. Public Law 96-510, as amended, 94 Stat. 2767, 42 USC 9601 et seq.

DOE/RL - U.S. Department of Energy, Richland Operations. 2004. Calendar Year 2003 Annual Summary Report for the 100-HR-3, 100-KR-4, and 100-NR-2 Operable Unit (OU) Pump \& Treat Operations. DOE/RL-2004-21, Rev. 0, Richland, Washington.

DOE/RL-U.S. Department of Energy, Richland Operations. 2006. Strontium-90 Treatability Test Plan for 100-NR-2 Groundwater Operable Unit. DOE/RL-2005-96, Rev. 0, Richland, Washington.

Hartman MH, LF Morasch, and WD Webber. 2007. Hanford Site Groundwater Monitoring for Fiscal Year 2006. PNNL-16346, Pacific Northwest National Laboratory, Richland, Washington.

Mendoza DP, GW Patton, MJ Hartman, FA Spane, MD Sweeney, BG Fritz, TJ Gilmore, RD Mackley, BN Bjornstad, and RE Clayton. 2007. Assessment of the Strontium-90 Contaminant Plume Along the Shoreline of the Columbia River at the 100-N Area of the Hanford Site. PNNL-16894, Pacific Northwest National Laboratory, Richland, Washington.

Szecsody JE, CA Burns, RC Moore, JS Fruchter, VR Vermeul, MD Williams, DC Girvin, JP McKinley, MJ Truex, and JL Phillips. 2007. Hanford 100-N Area Apatite Emplacement: Laboratory Results of CaCitrate- $\mathrm{PO}_{4}$ Solution Injection and Sr-90 Immobilization in 100-N Sediments. PNNL-16891, Pacific Northwest National Laboratory, Richland, Washington.

Szecsody JE, ML Rockhold, M Oostrom, RC Moore, CA Burns, MD Williams, L Zhong, JS Fruchter, JP McKinley, VR Vermeul, MA Covert, TW Wietsma, AT Breshears, and BJ Garcia. 2009. Sequestration of Sr-90 Subsurface Contamination in the Hanford 100N Area by Surface Infiltration of a Ca-CitratePO4 Solution. PNNL-18303, Pacific Northwest National Laboratory, Richland, Washington.

Szecsody J, V Vermeul, J Fruchter, M Williams, M Rockhold, and J. Phillips. 2010. Hanford 100N Area In Situ Apatite and Phosphate Emplacement by Groundwater and Jet Injection: Geochemical and Physical Core Analysis. PNNL-19524, Pacific Northwest National Laboratory, Richland, Washington.

Vermeul, VR, BG Fritz, JD Fruchter, JE Szecsody and MD Williams. 2010. 100-NR-2 Apatite Treatability Test: High-Concentration Calcium-Citrate-Phosphate Solution Injection for In Situ Strontium-90 Immobilization. PNNL-19572, Pacific Northwest National Laboratory, Richland, Washington.

Williams MD, BG Fritz, DP Mendoza, ML Rockhold, PD Thorne, YL Xie, BN Bjornstad, RD Mackley, JE Szecsody and VR Vermeul. 2008. 100-NR-2 Apatite Treatability Test: Low Concentration Calcium Citrate-Phosphate Solution Injection for In Situ Strontium-90 Immobilization. PNNL-17429, Pacific Northwest National Laboratory, Richland, Washington. 



\section{Appendix A}

\section{Barrier Performance: Compliance Wells-}

$8 / 1 / 08$ through $10 / 31 / 10$ 



\section{Appendix A}

\section{Barrier Performance: Compliance Wells- $8 / 1 / 08$ through $10 / 31 / 10$}

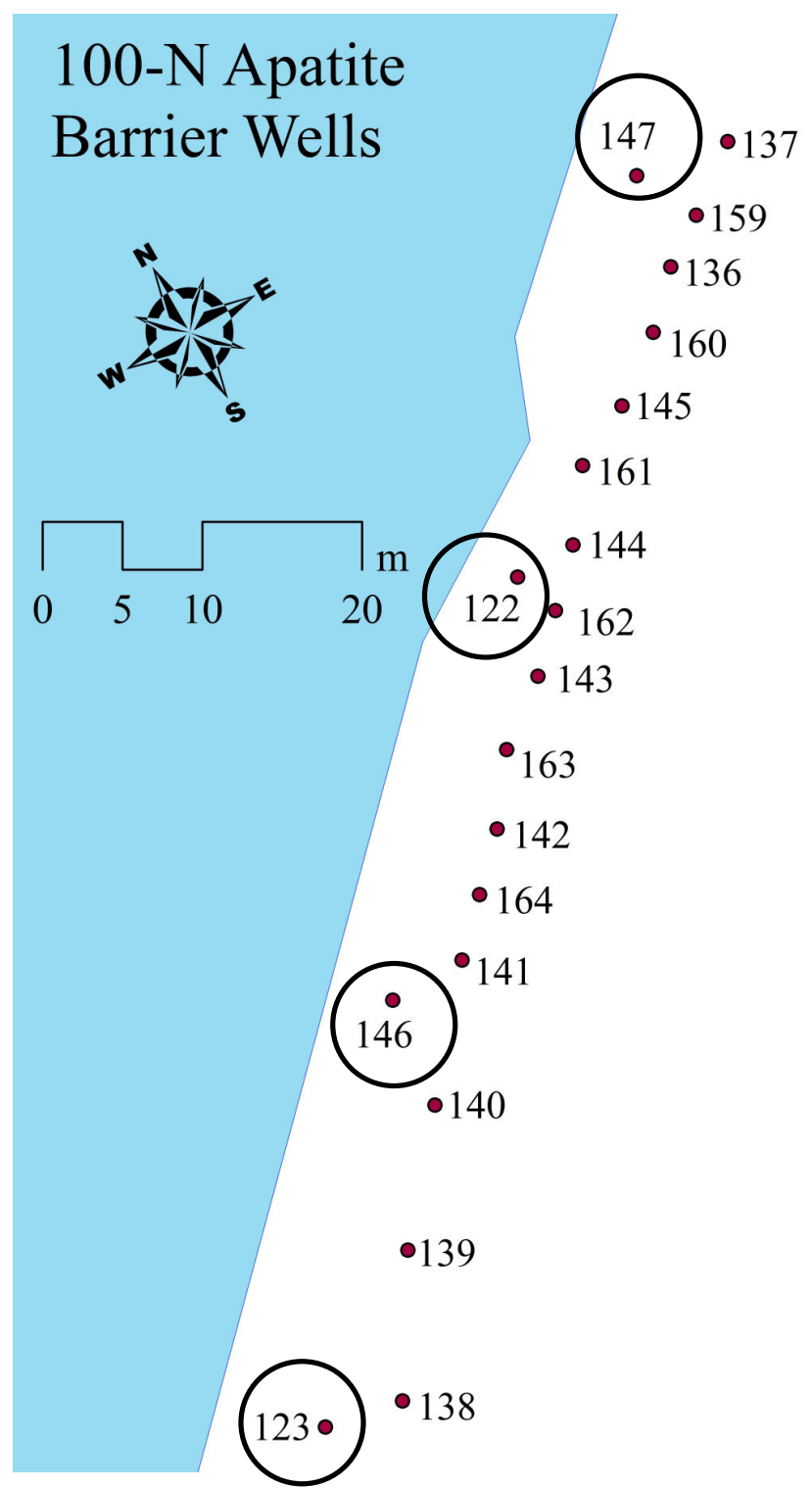

Figure A.1. Location of Compliance Wells for the Reactive Barrier- 138 through 145, and 159 through 164 are injection wells. 


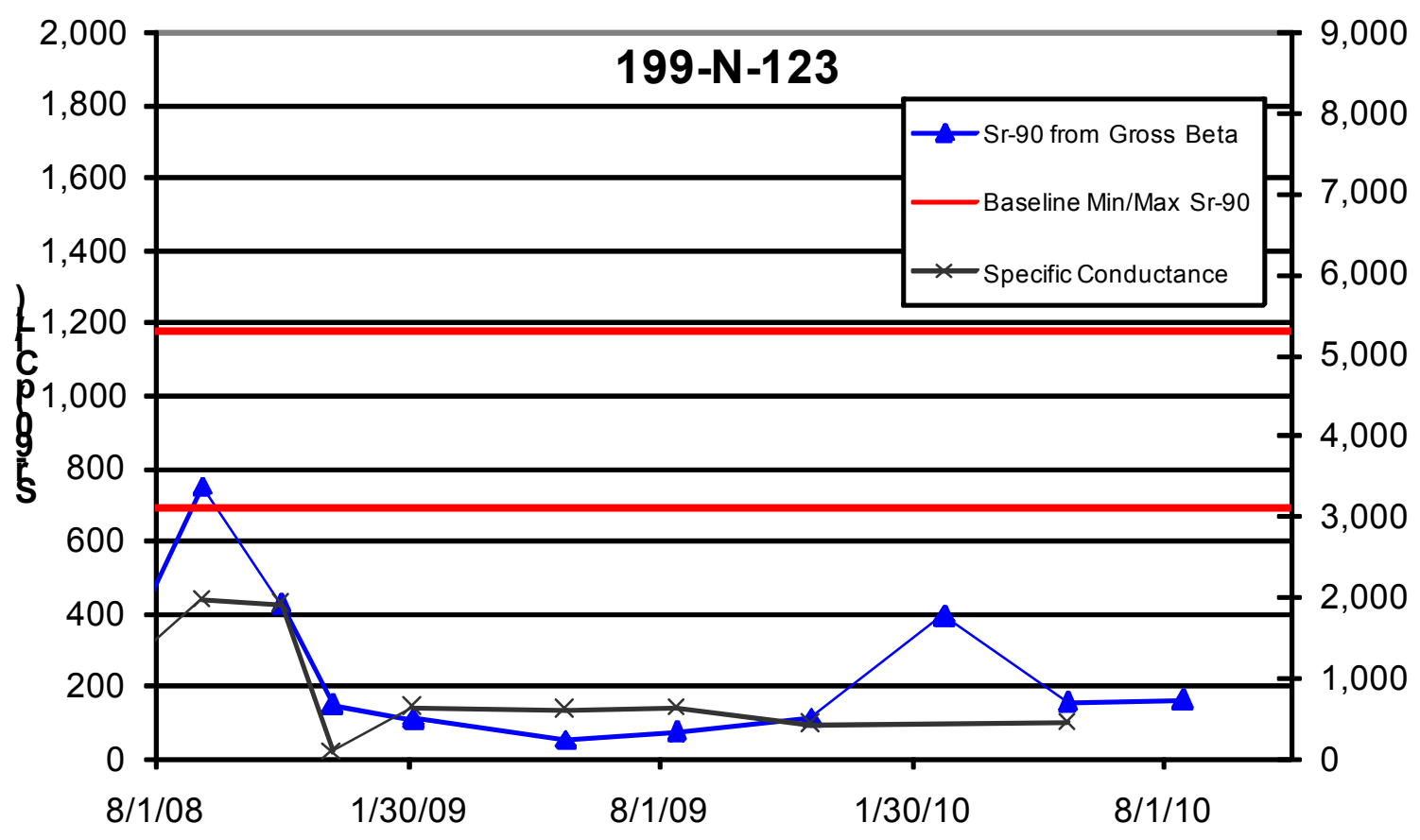

Figure A.2. Performance Plots for Well 199-N-123

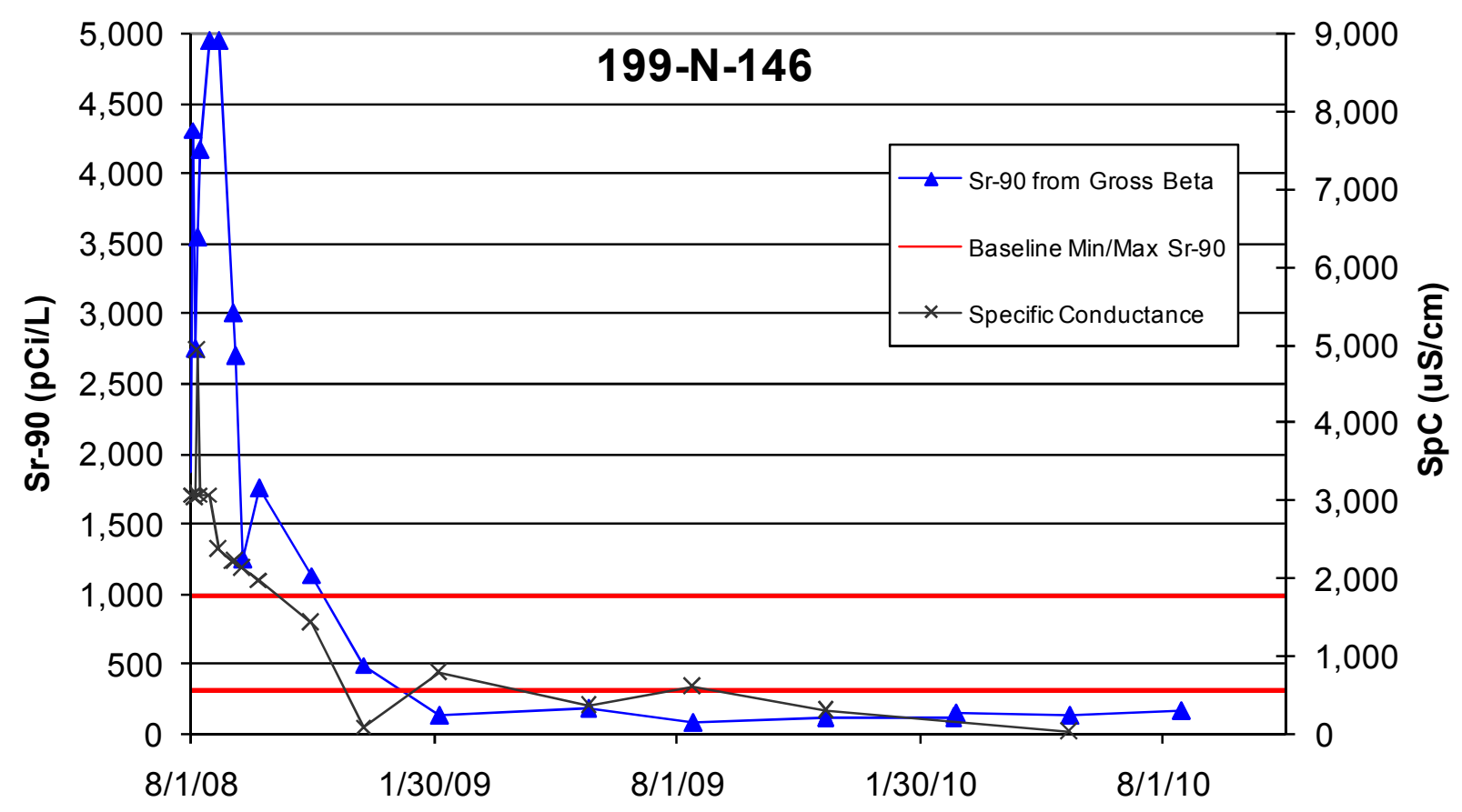

Figure A.3. Performance Plots for Well 199-N-146 


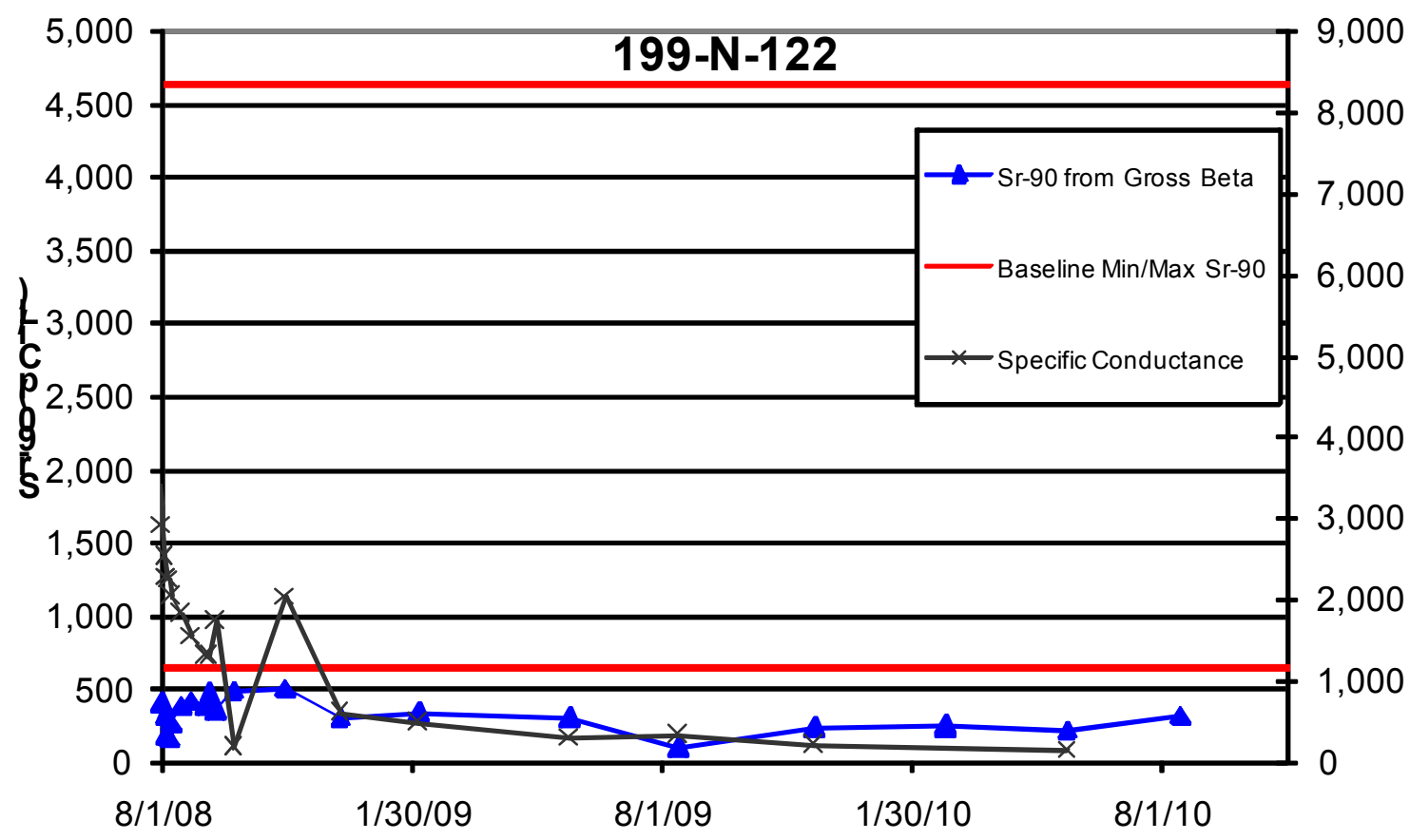

Figure A.4. Performance Plots for Well 199-N-122

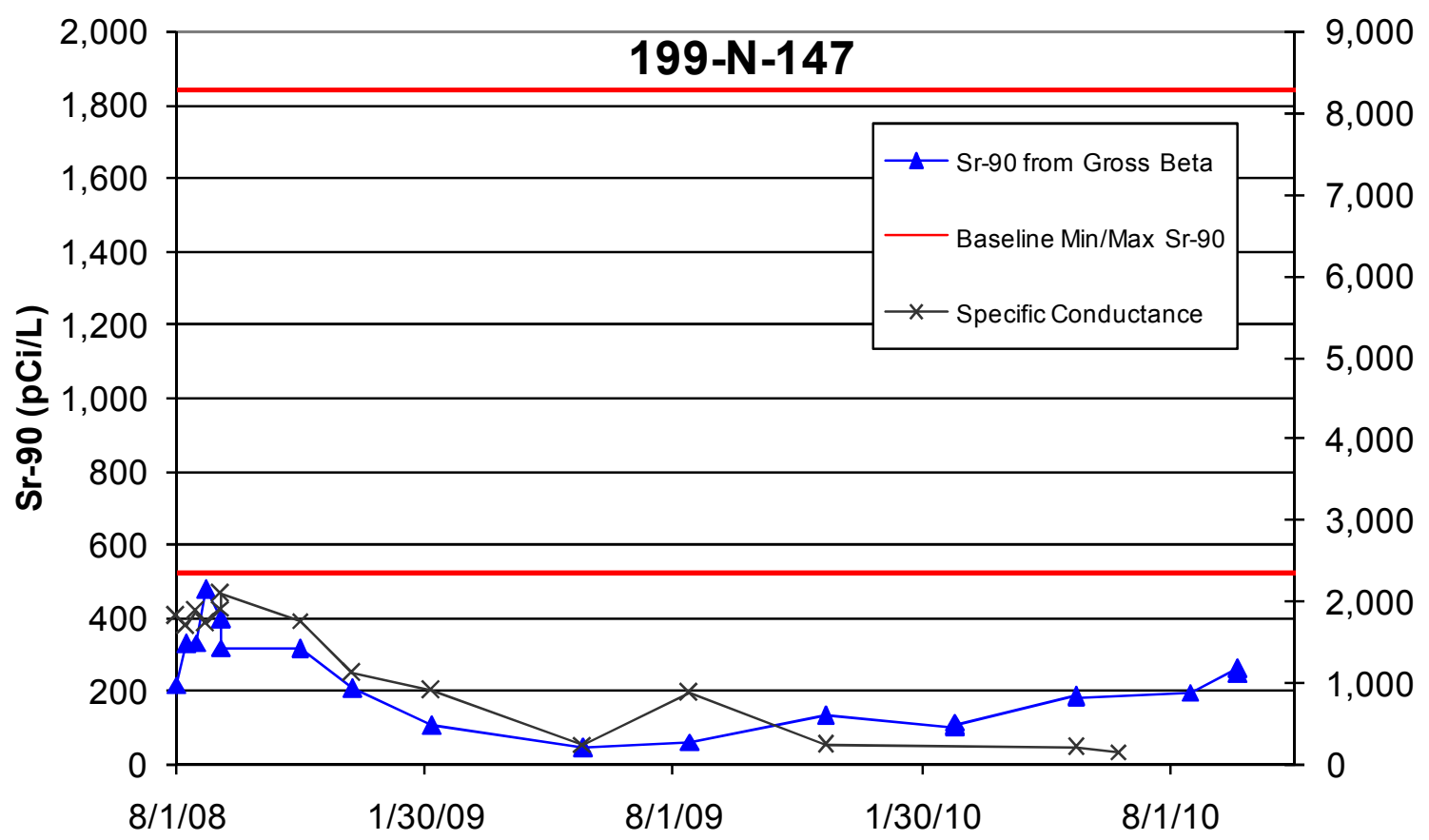

Figure A.5. Performance Plots for Well 199-N-147 



\section{Appendix B}

\section{Barrier Performance: Injection Wells- $8 / 1 / 08$ through $10 / 31 / 10$}





\section{Appendix B}

\section{Barrier Performance: Injection Wells- $8 / 1 / 08$ through $10 / 31 / 10$}

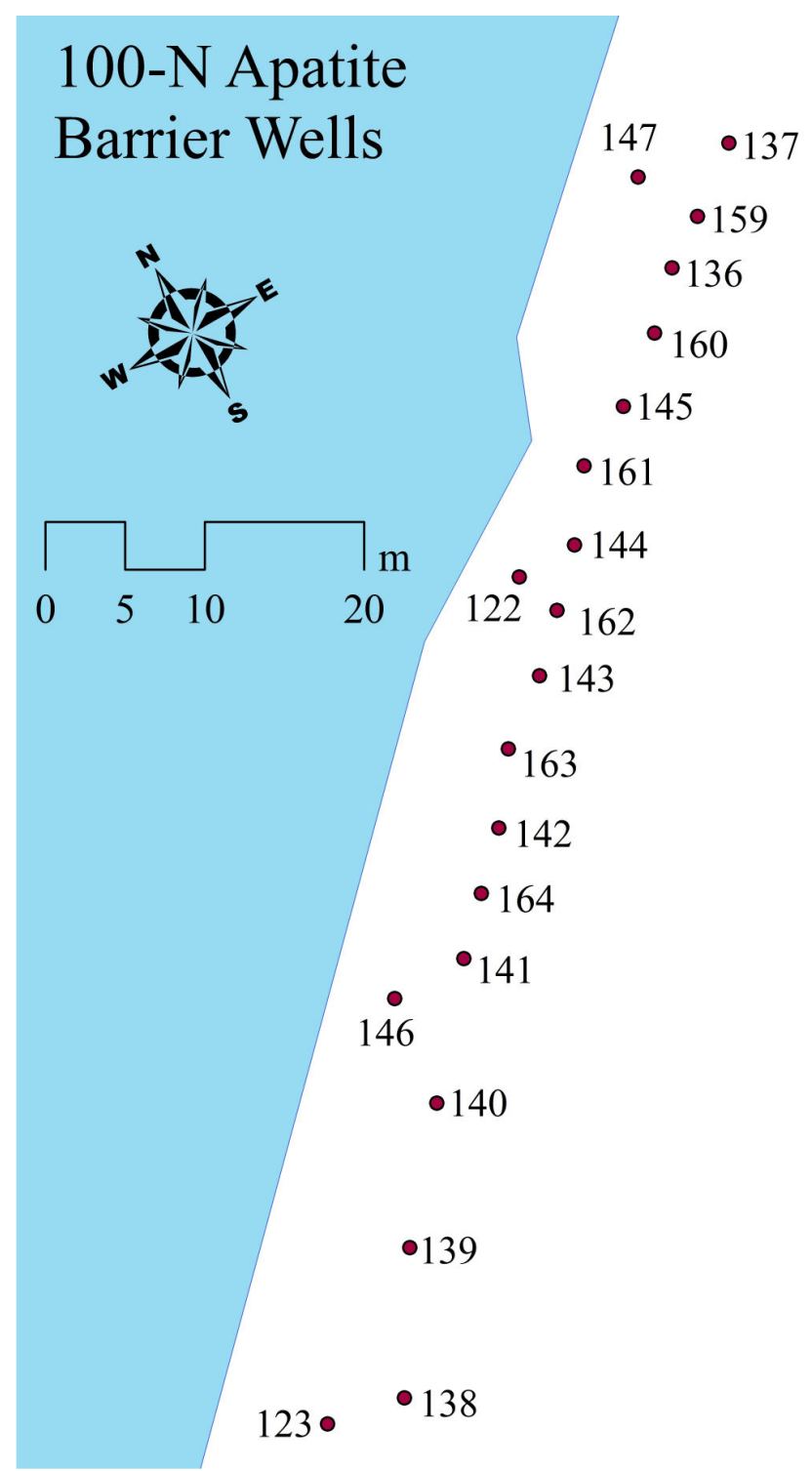

Figure B.1. Location of Injection Monitoring Wells Along the Reactive Barrier (Except 199-N-122, 123, 146 and -147 , which are compliance monitoring wells). 


\section{B.1. Fully Screened Hanford-Ringold Wells}

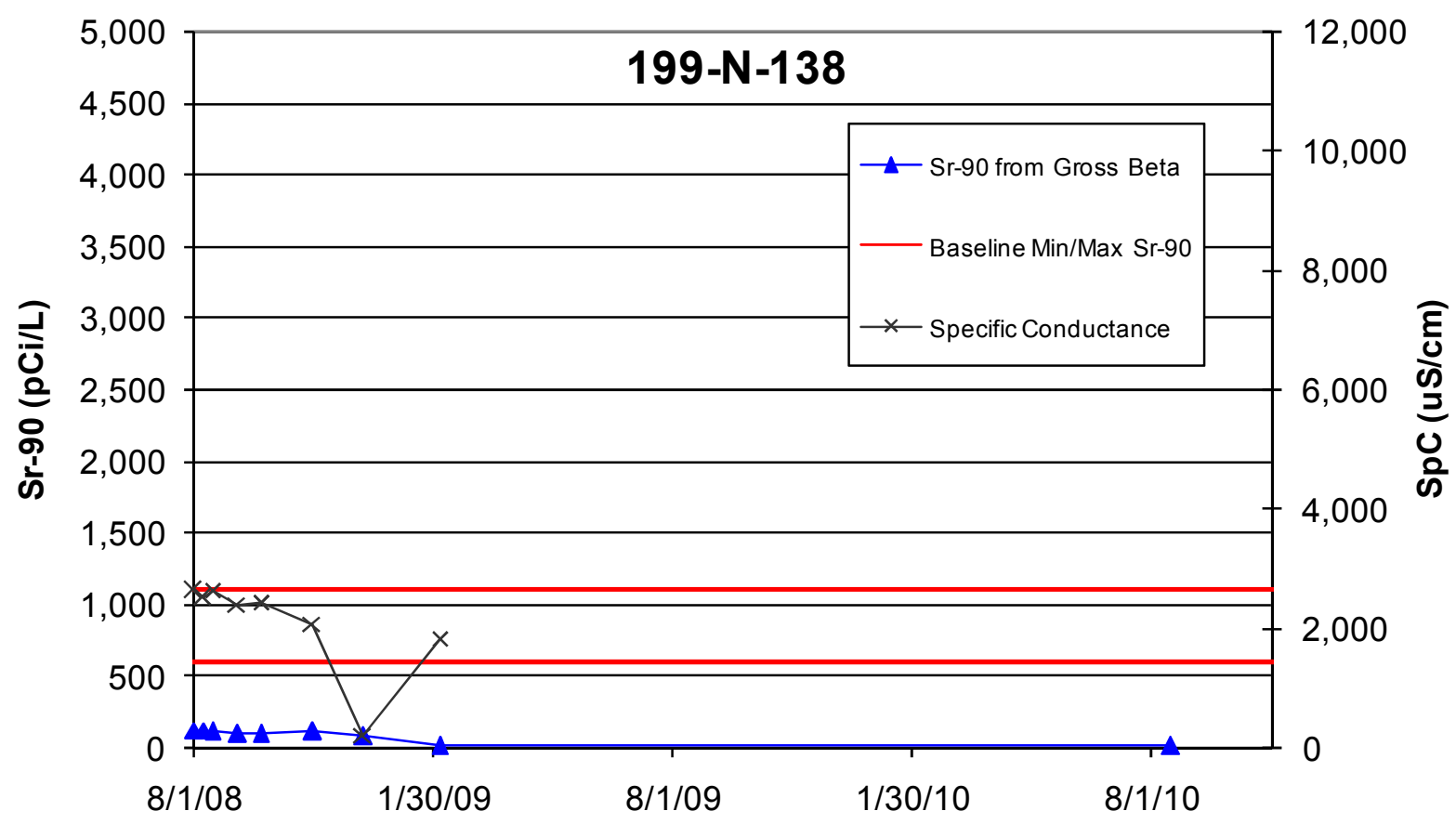

Figure B.2. Performance Plots for Well 199-N-138

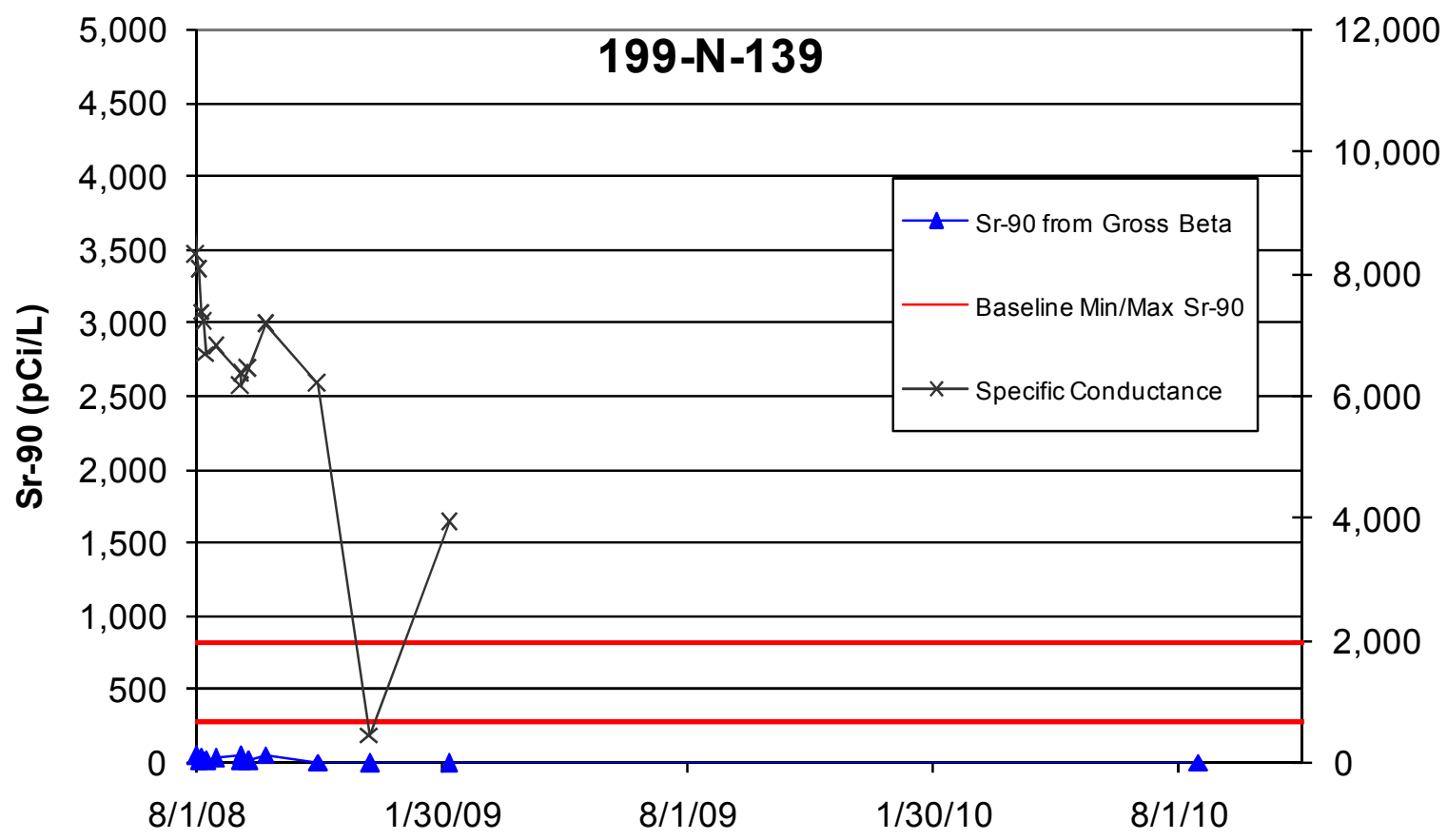

Figure B.3. Performance Plots for Well 199-N-139 


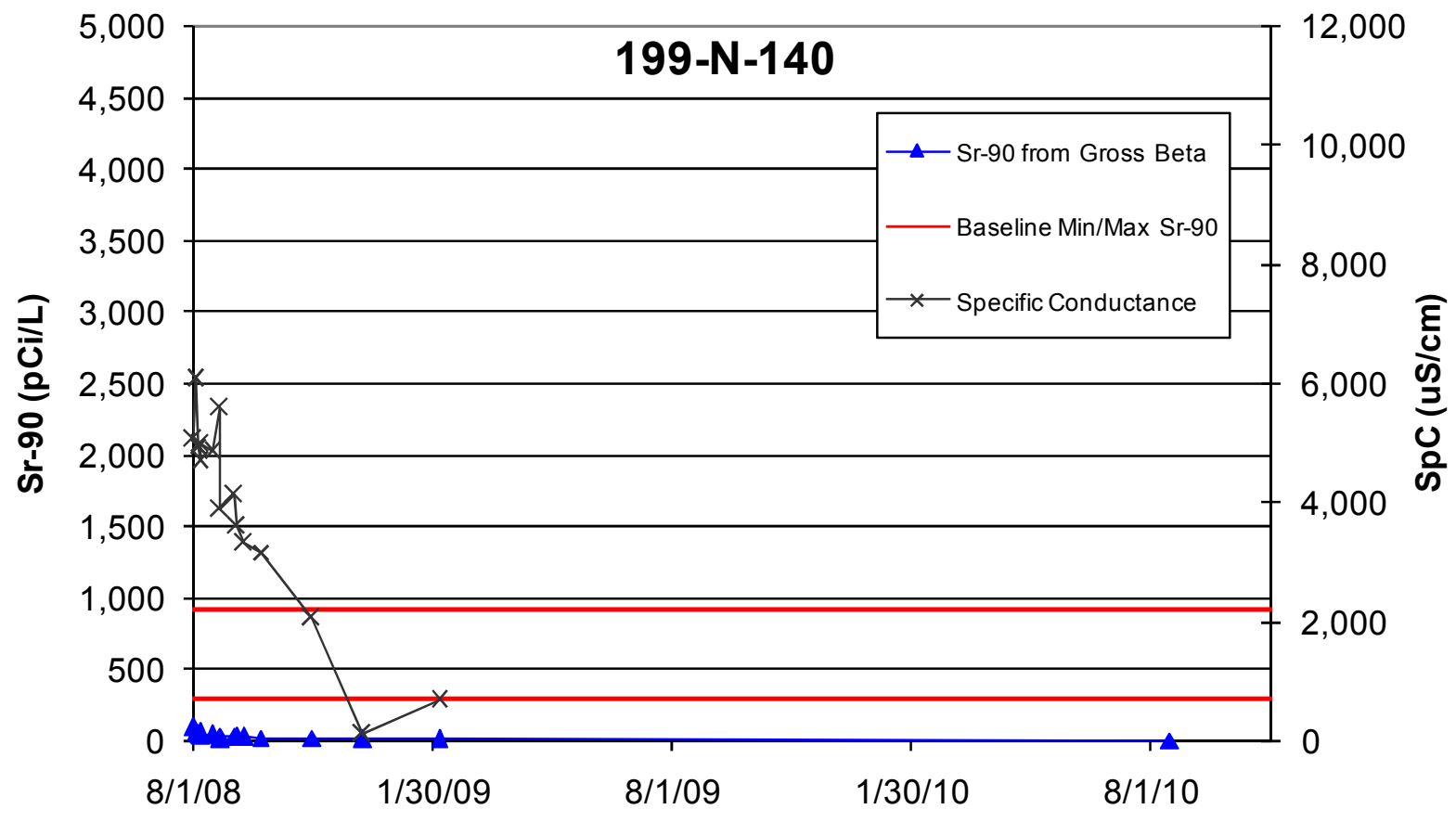

Figure B.4. Performance Plots for Well 199-N-140

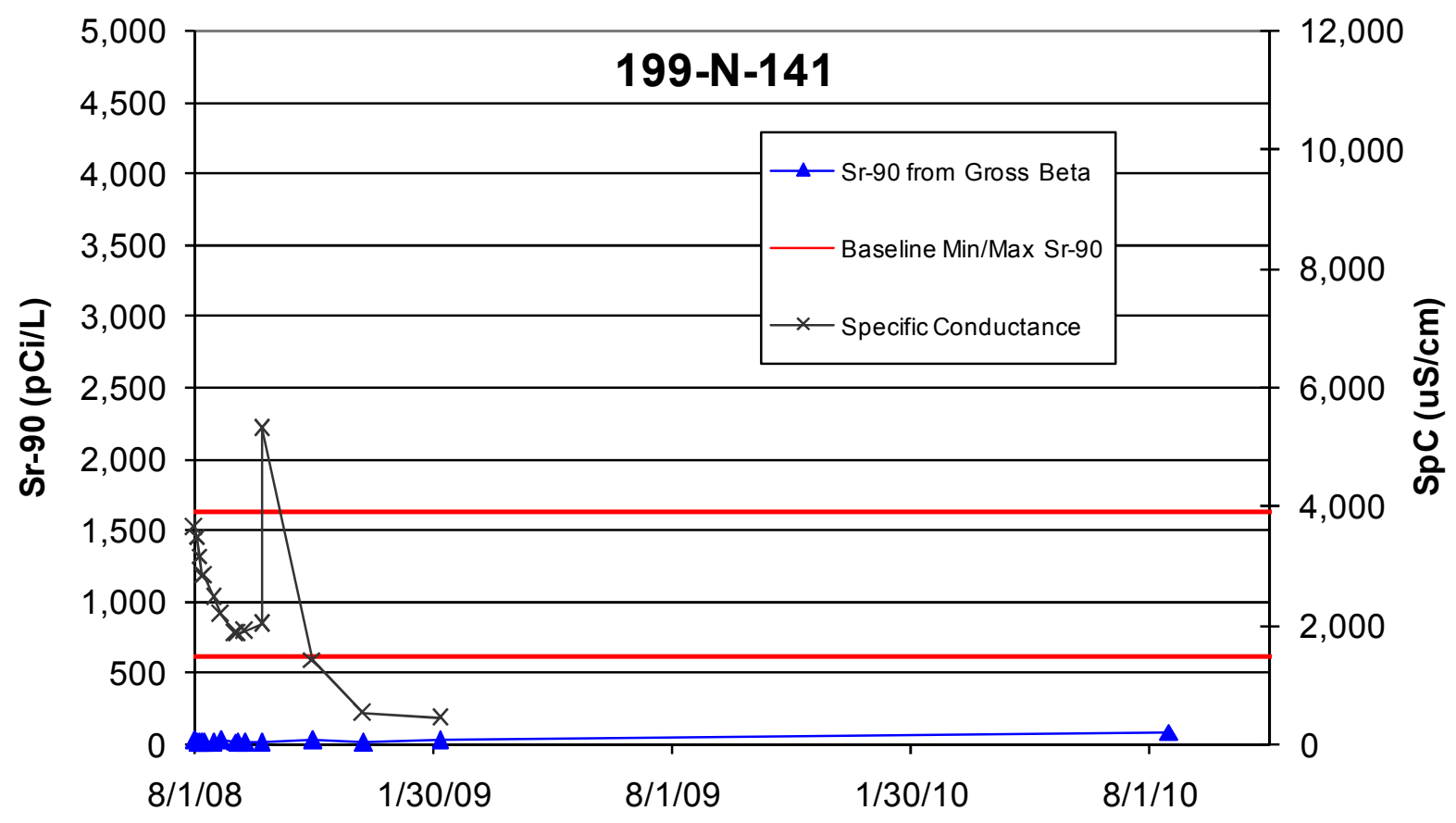

Figure B.5. Performance Plots for Well 199-N-141 


\section{B.2. Hanford-Only Treatment Wells}

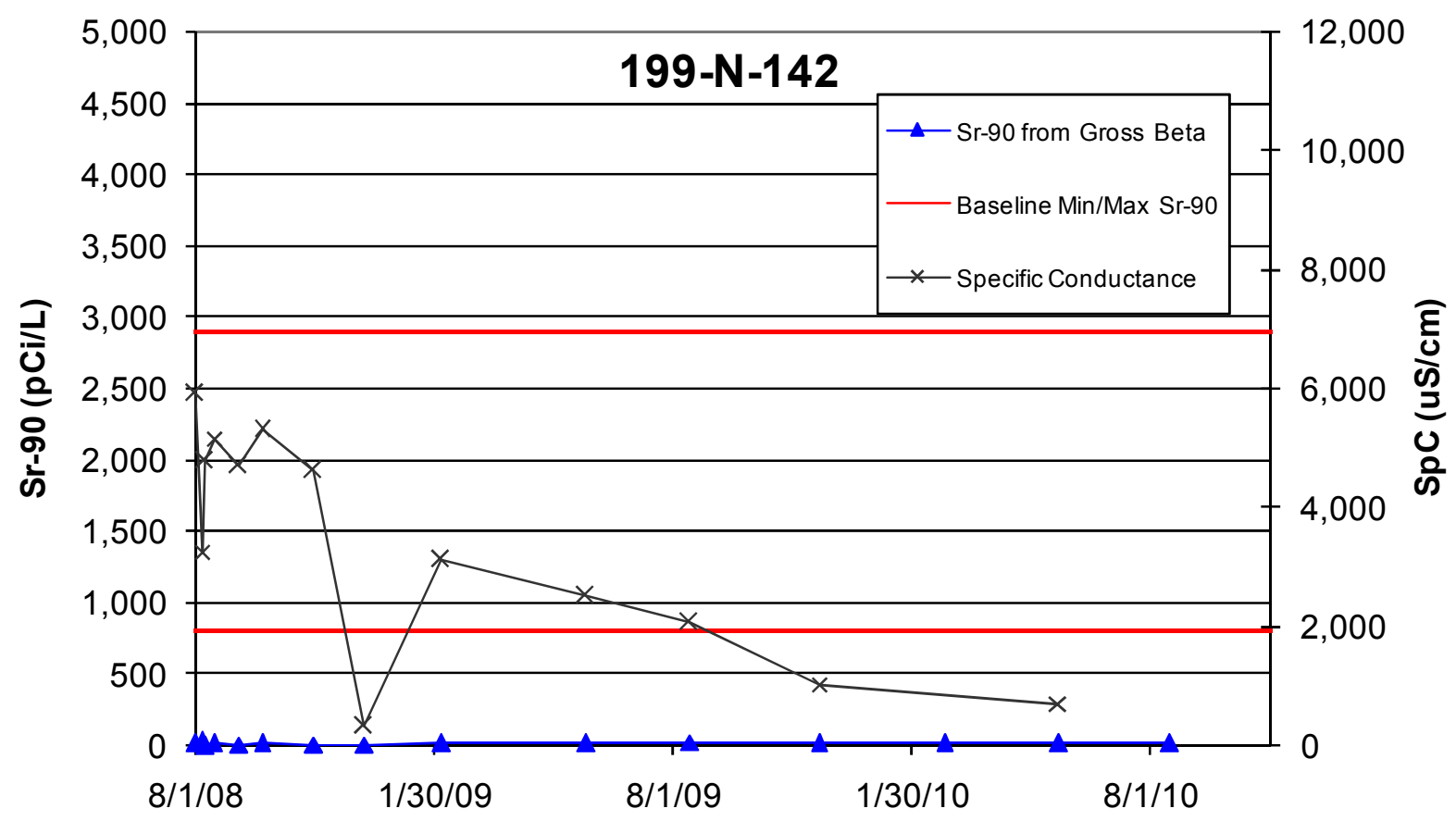

Figure B.6. Performance Plots for Well 199-N-142

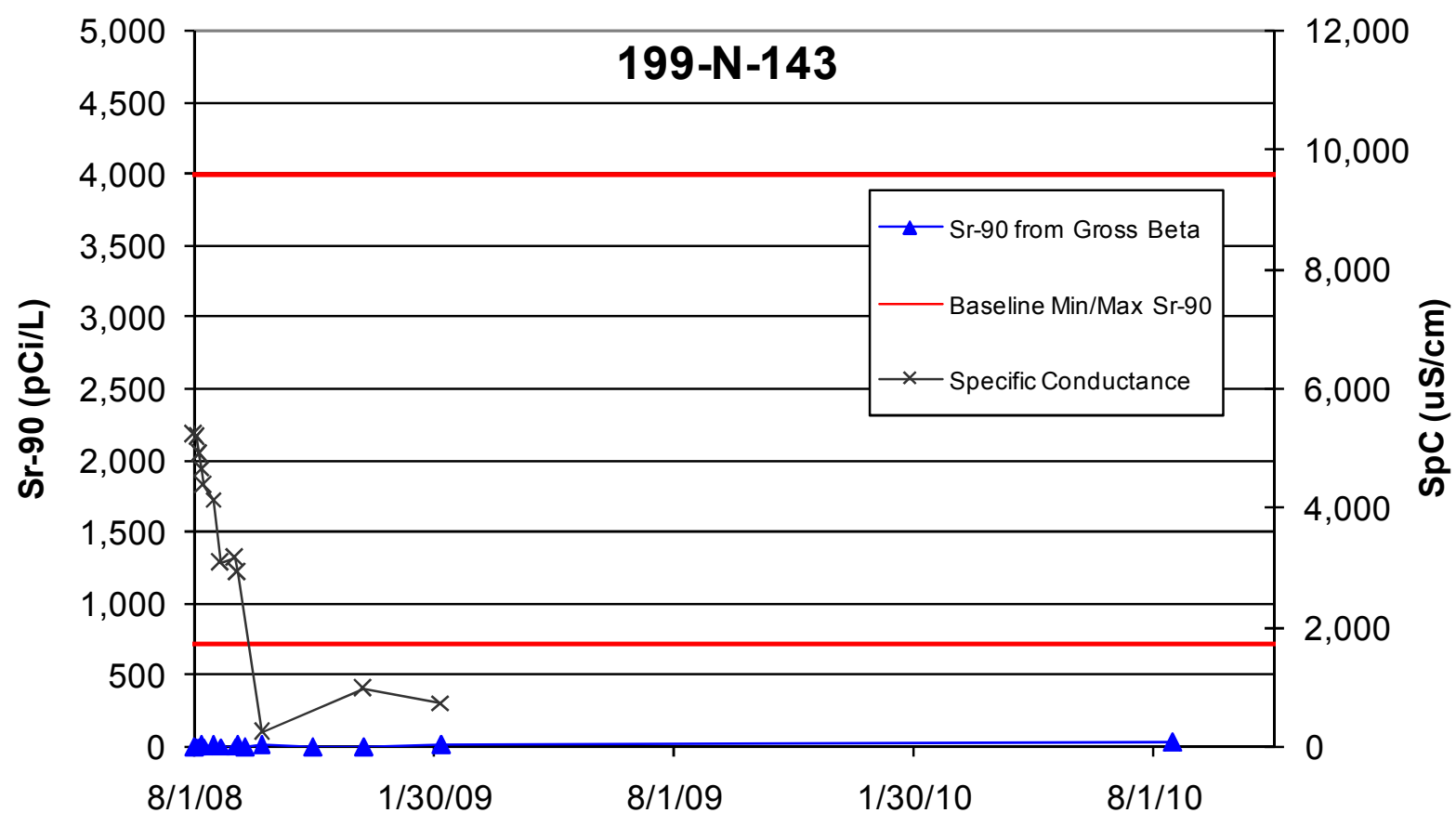

Figure B.7. Performance Plots for Well 199-N-143 


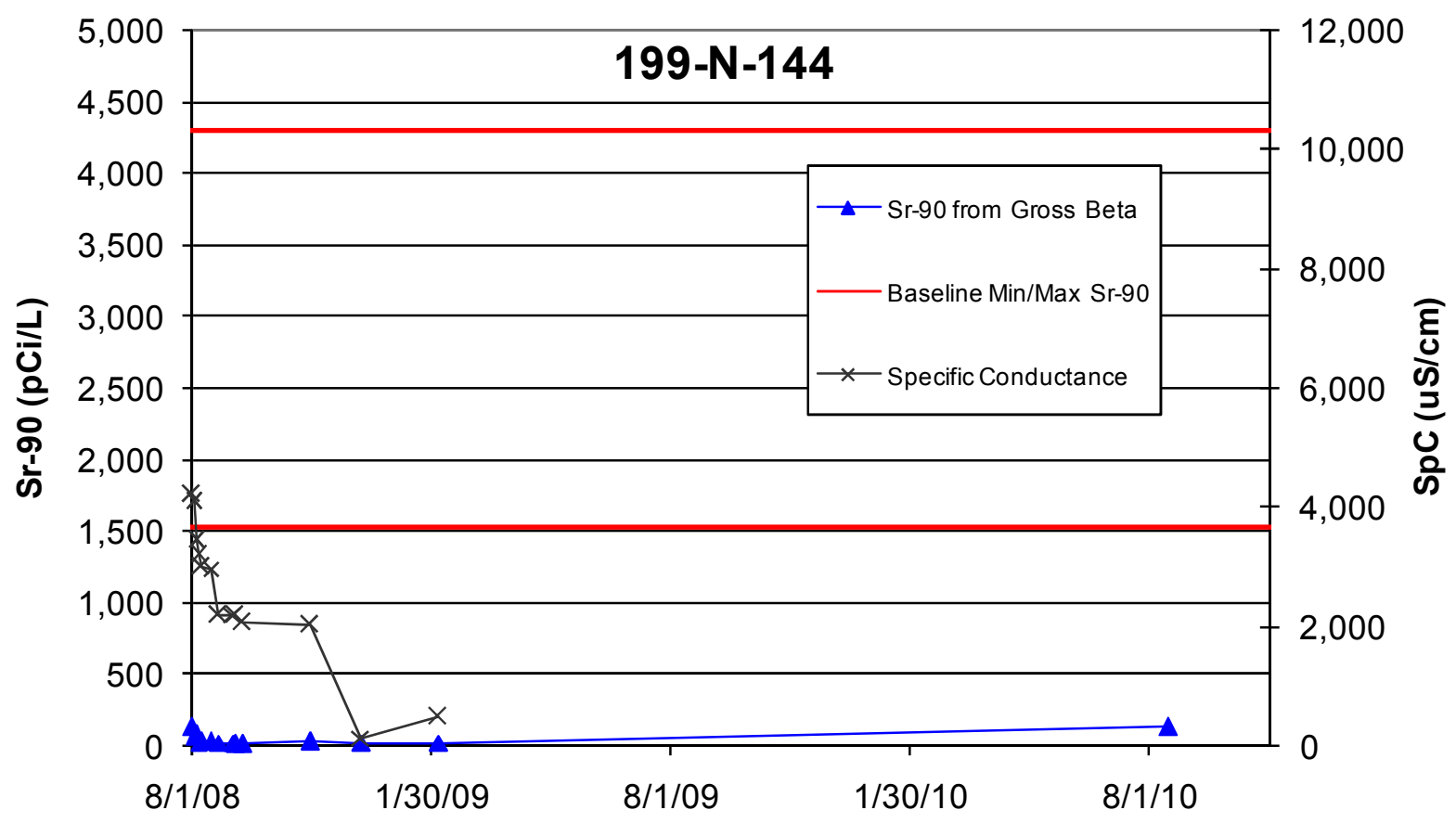

Figure B.8. Performance Plots for Well 199-N-144

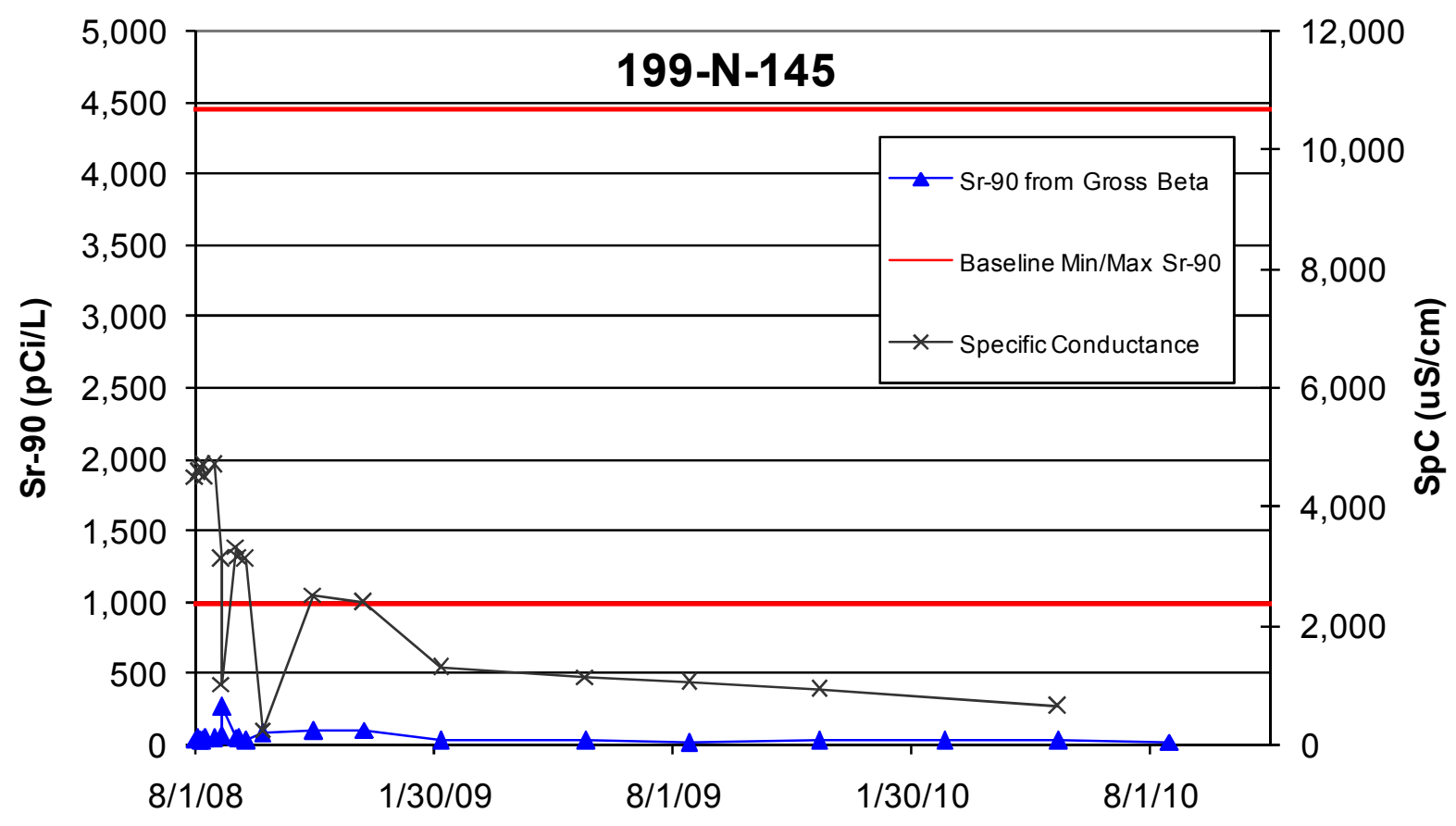

Figure B.9. Performance Plots for Well 199-N-145 


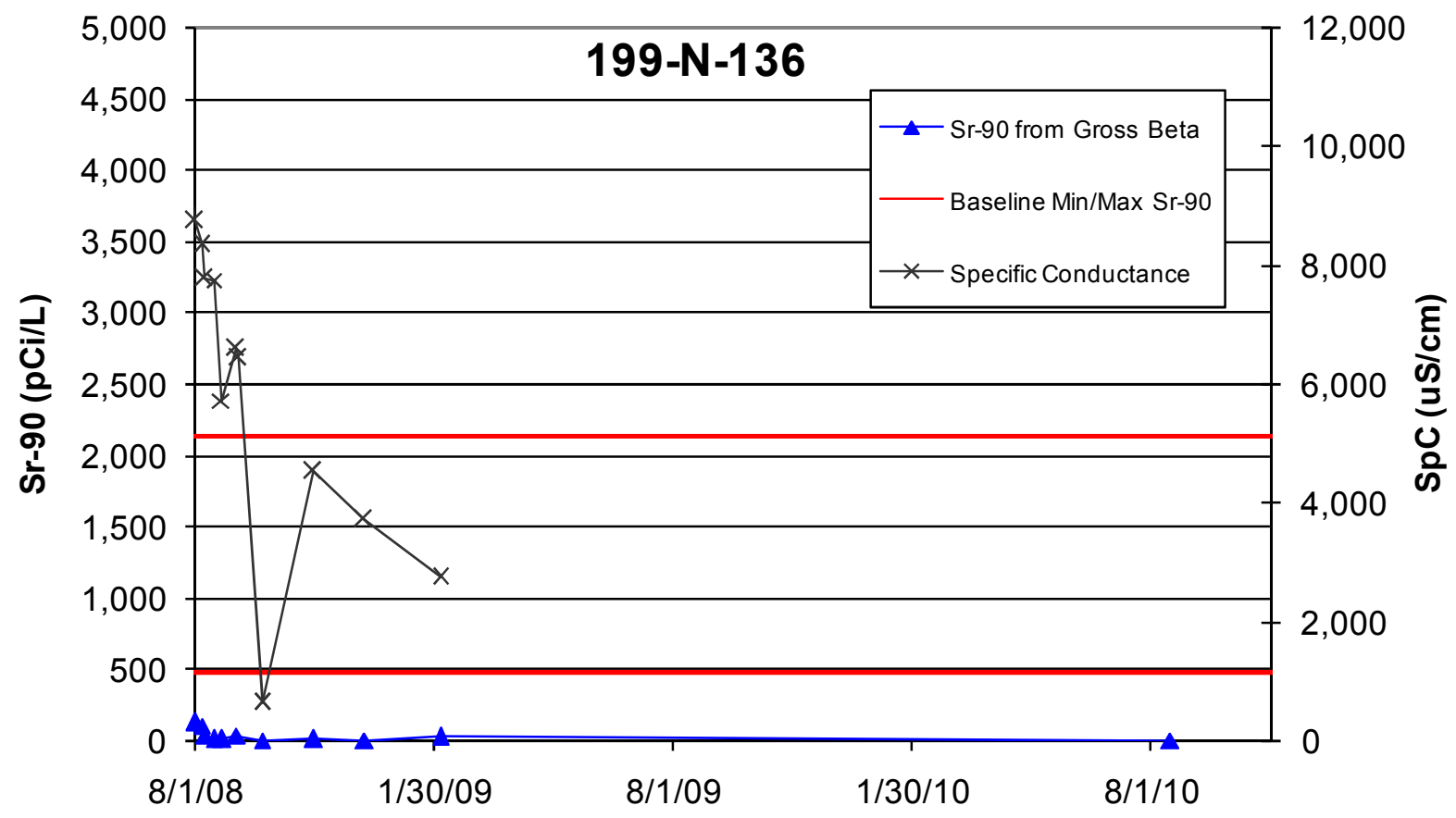

Figure B.10. Performance Plots for Well 199-N-136

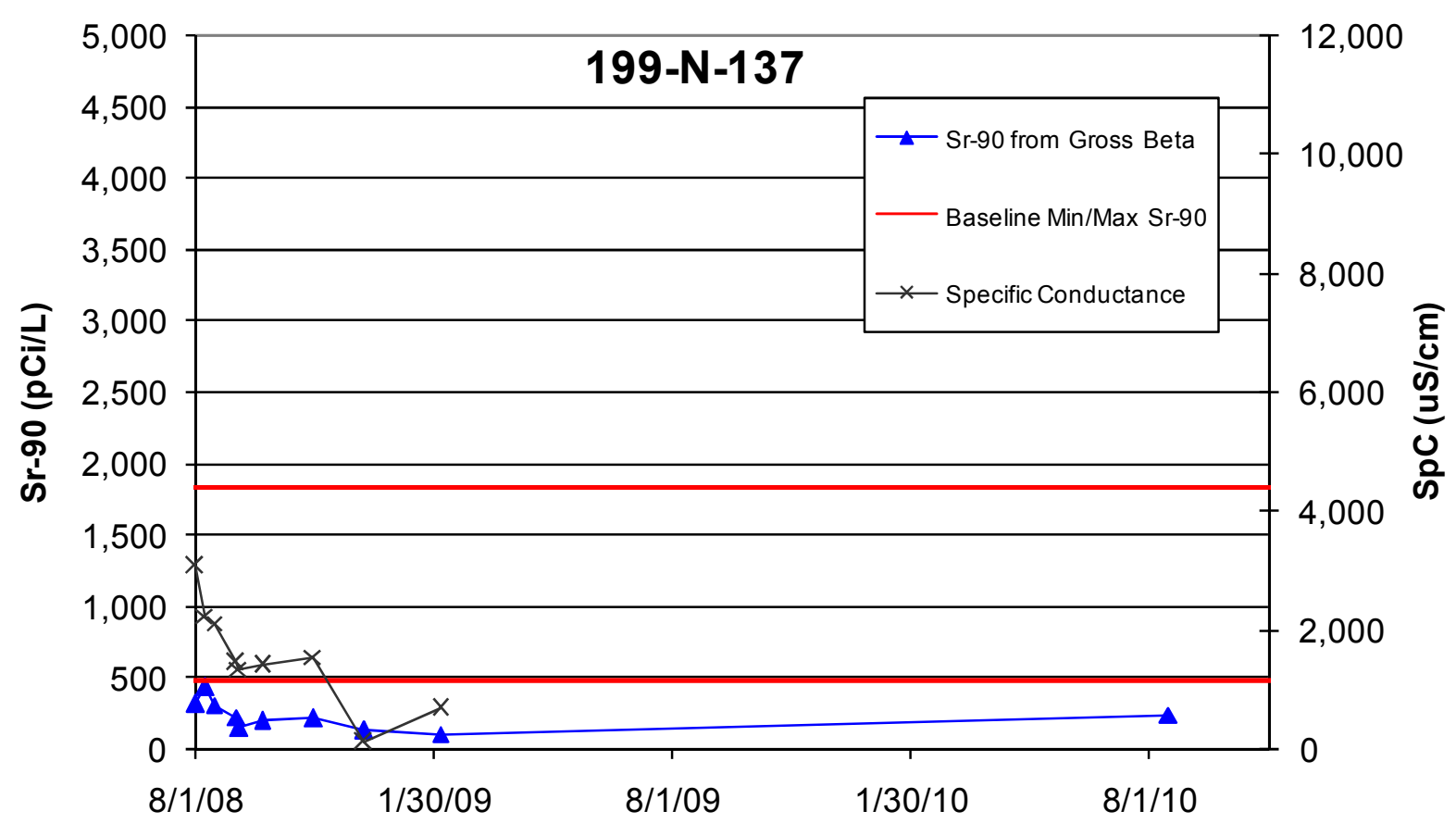

Figure B.11. Performance Plots for Well 199-N-137 


\section{B.3. Ringold-Only Treatment Wells}

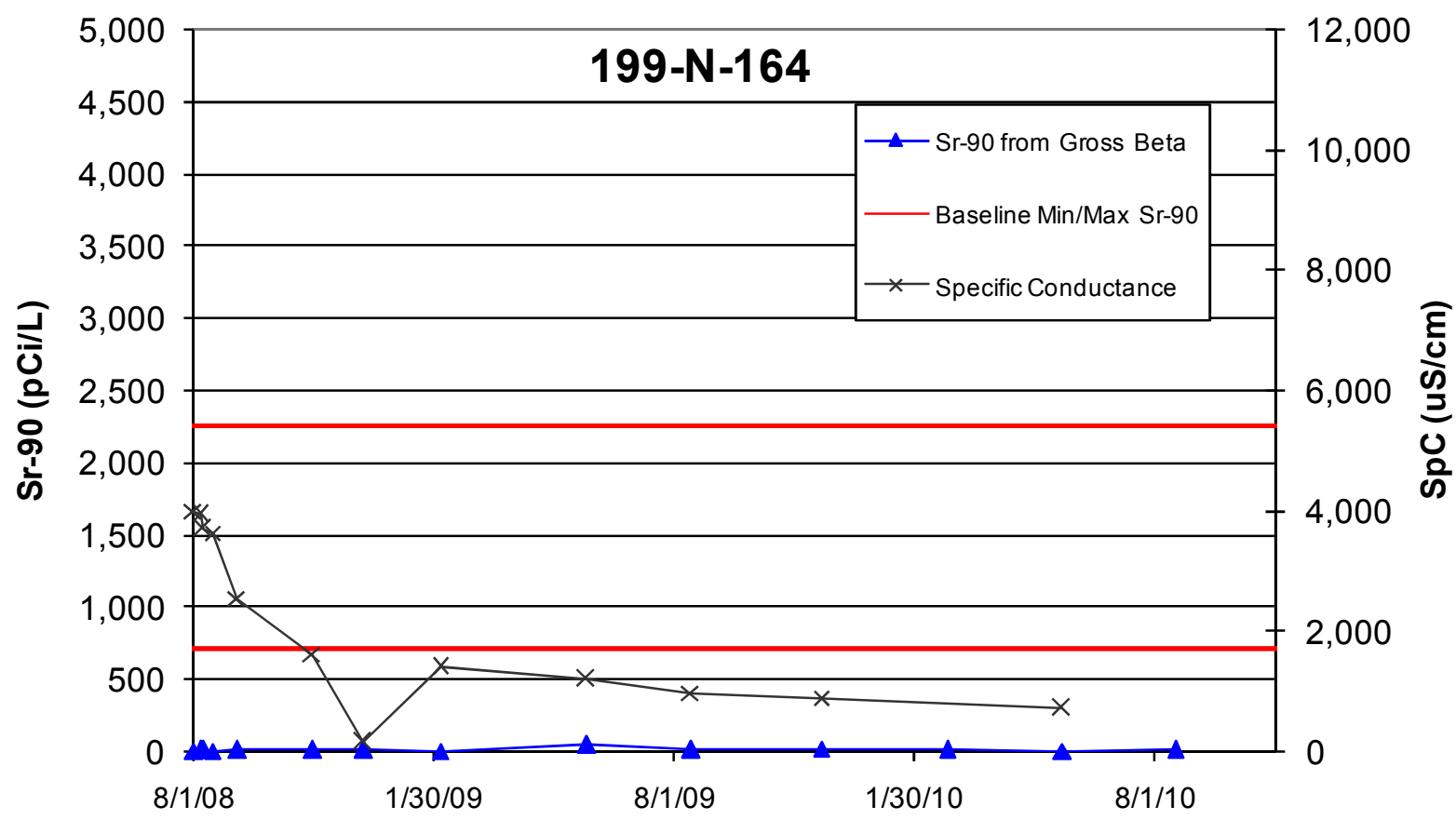

Figure B.12. Performance Plots for Well 199-N-164

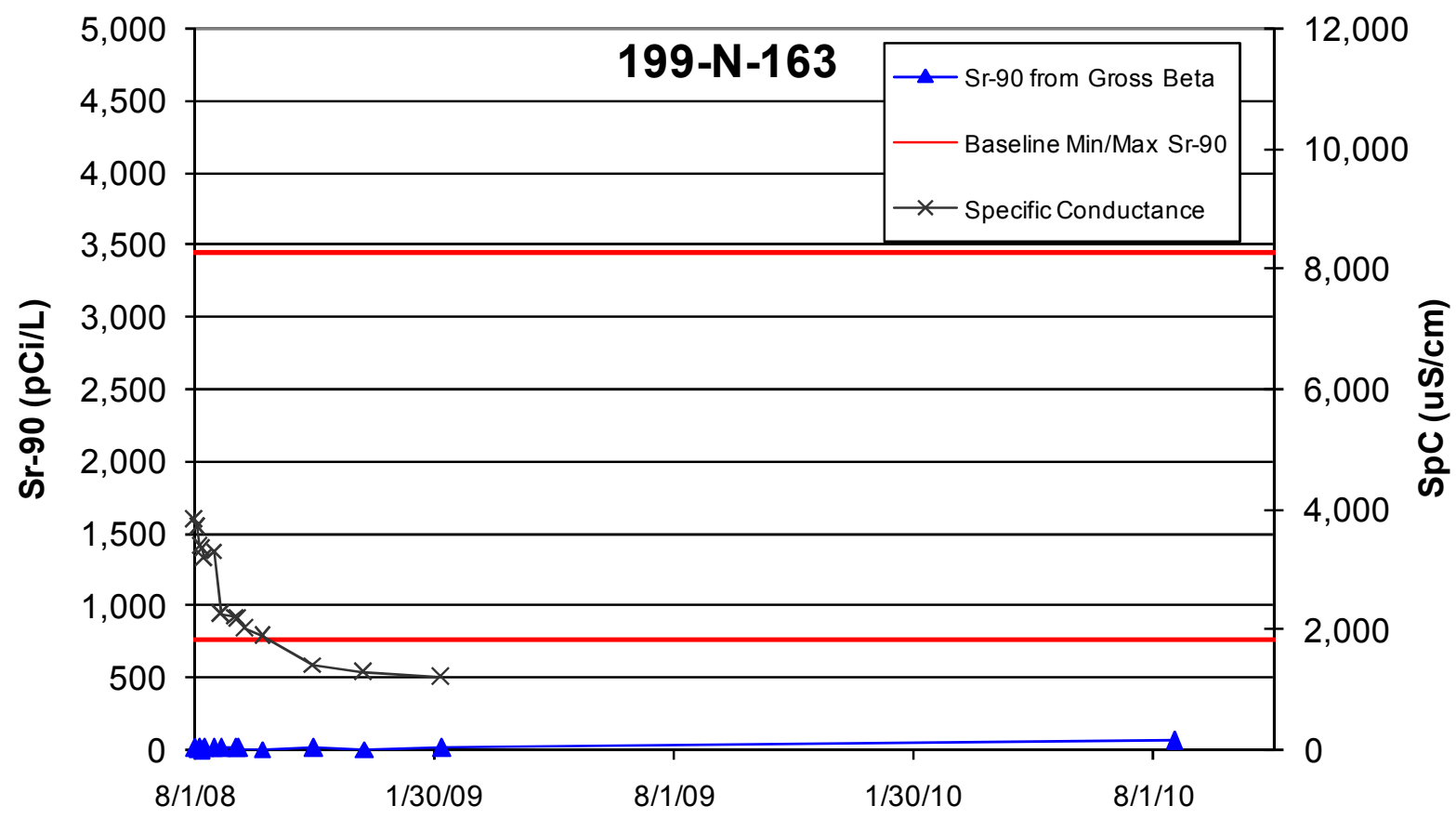

Figure B.13. Performance Plots for Well 199-N-163 


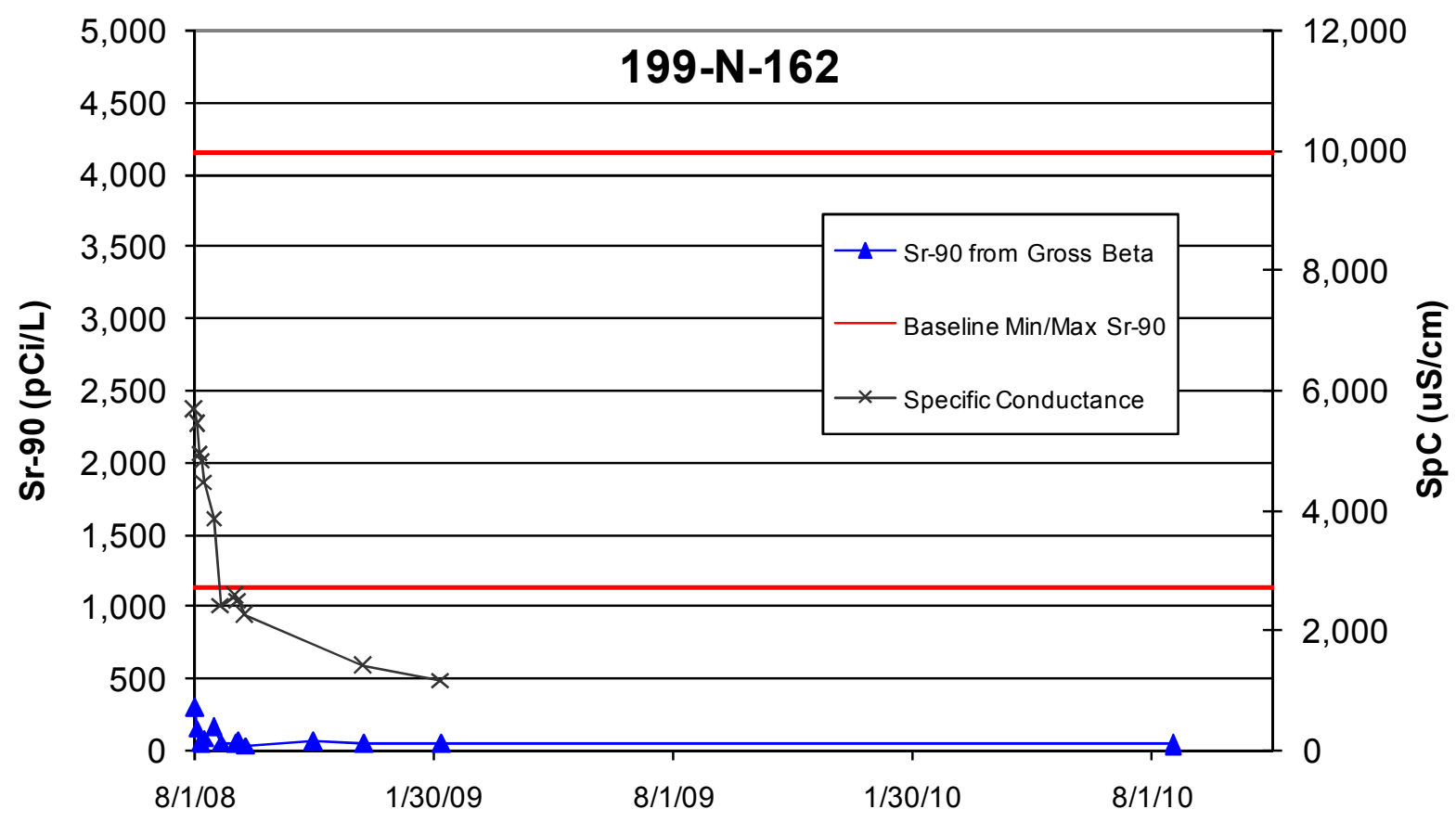

Figure B.14. Performance Plots for Well 199-N-162

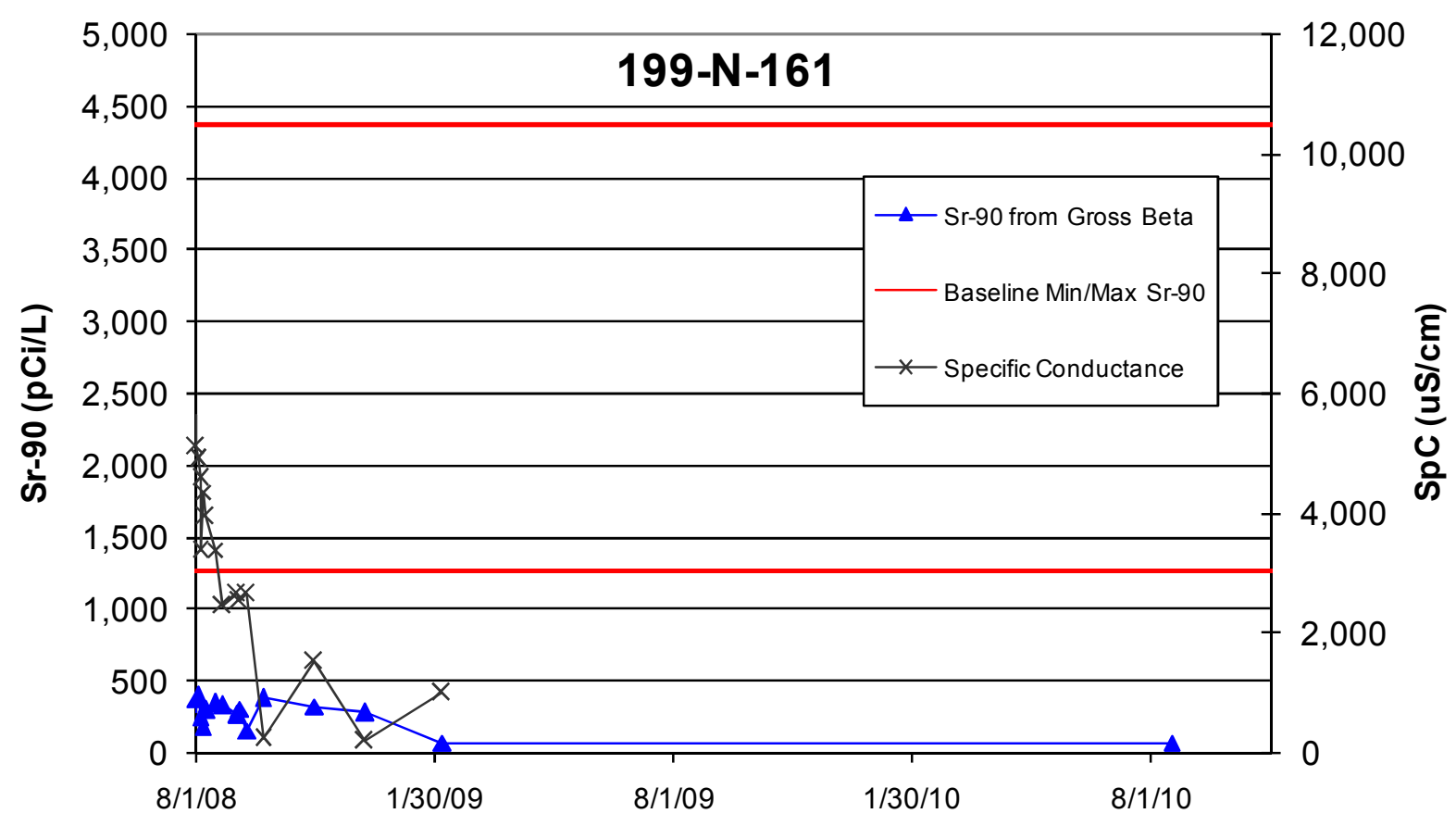

Figure B.15. Performance Plots for Well 199-N-161 


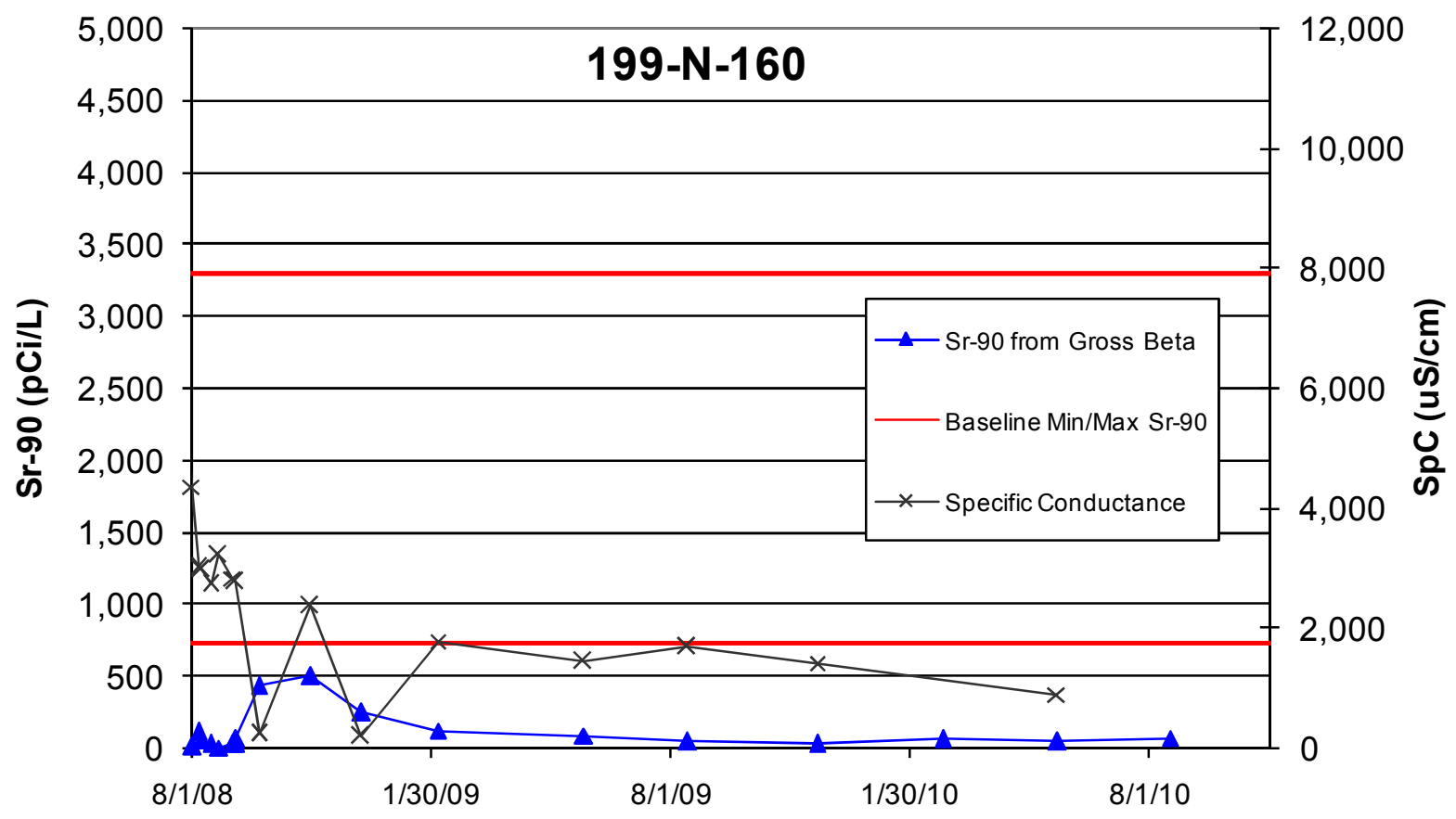

Figure B.16. Performance Plots for Well 199-N-160

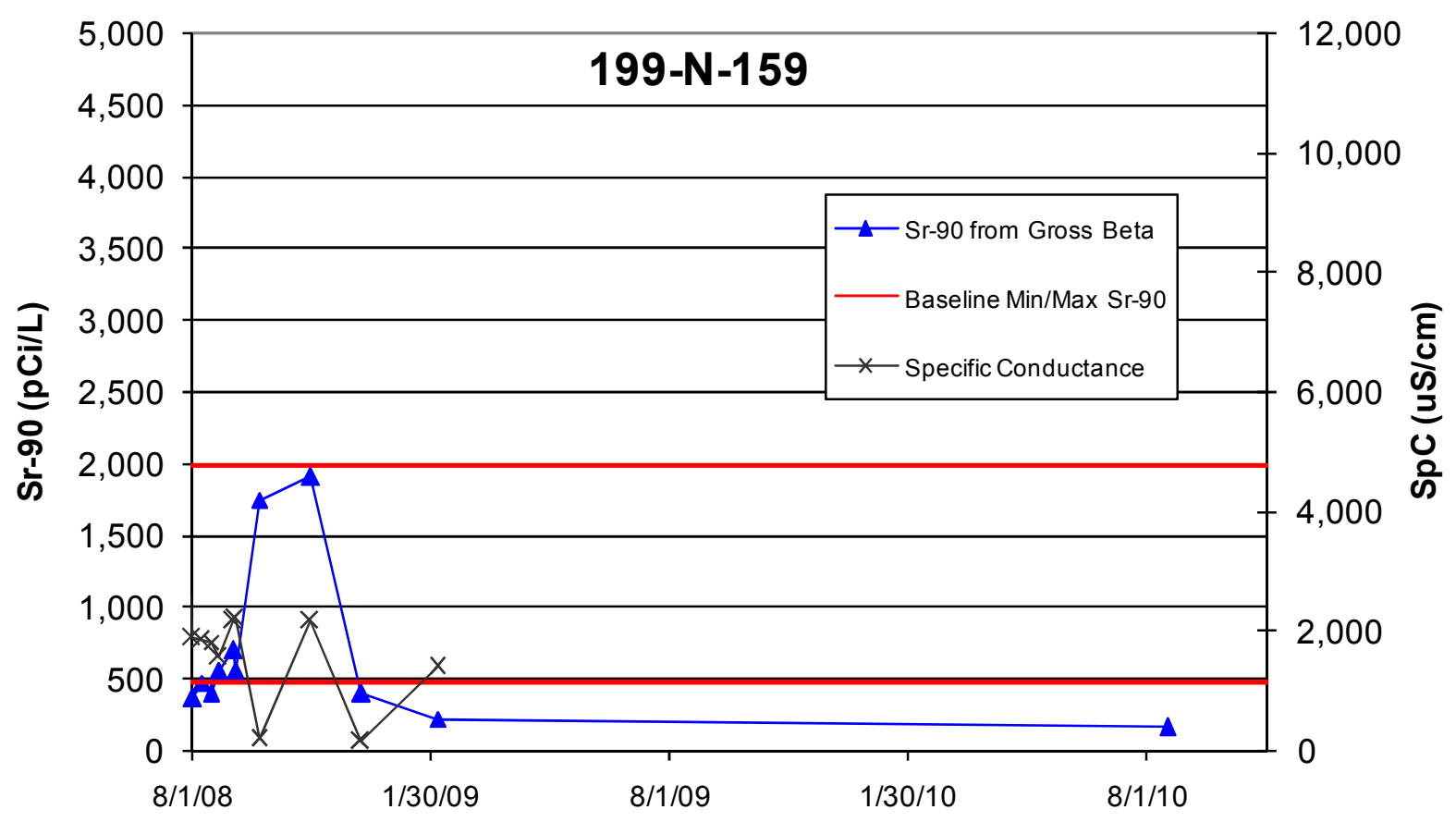

Figure B.17. Performance Plots for Well 199-N-159 



\section{Appendix C}

\section{Barrier Performance: Pilot Site Wells-}

$8 / 1 / 08$ through $10 / 31 / 10$ 



\section{Appendix C: Barrier Performance: Pilot Site Wells- $8 / 1 / 08$ through $10 / 31 / 10$}

\section{C.1 Pilot Site 1}

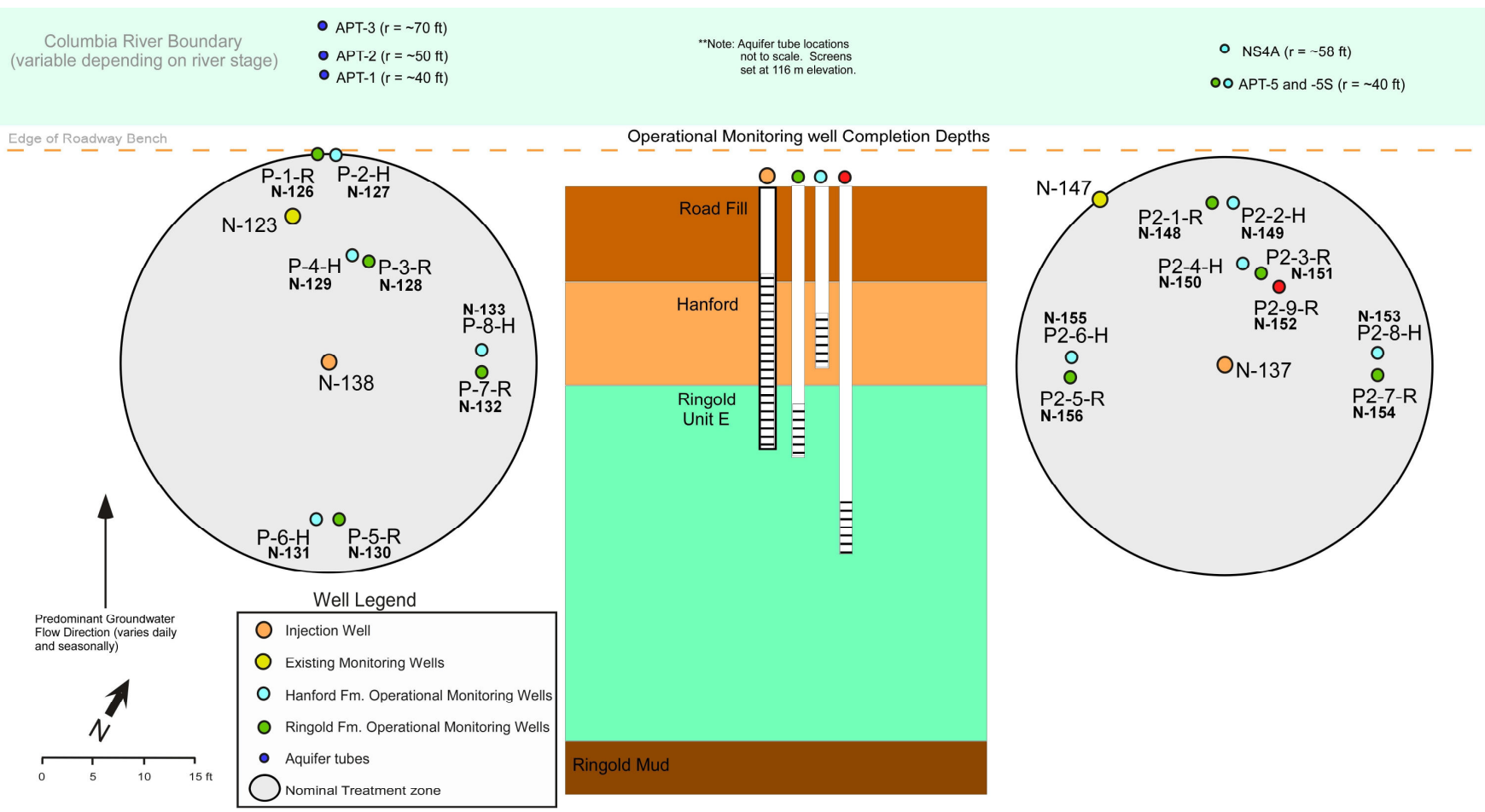

Figure C.1. Map of Pilot Test Sites 


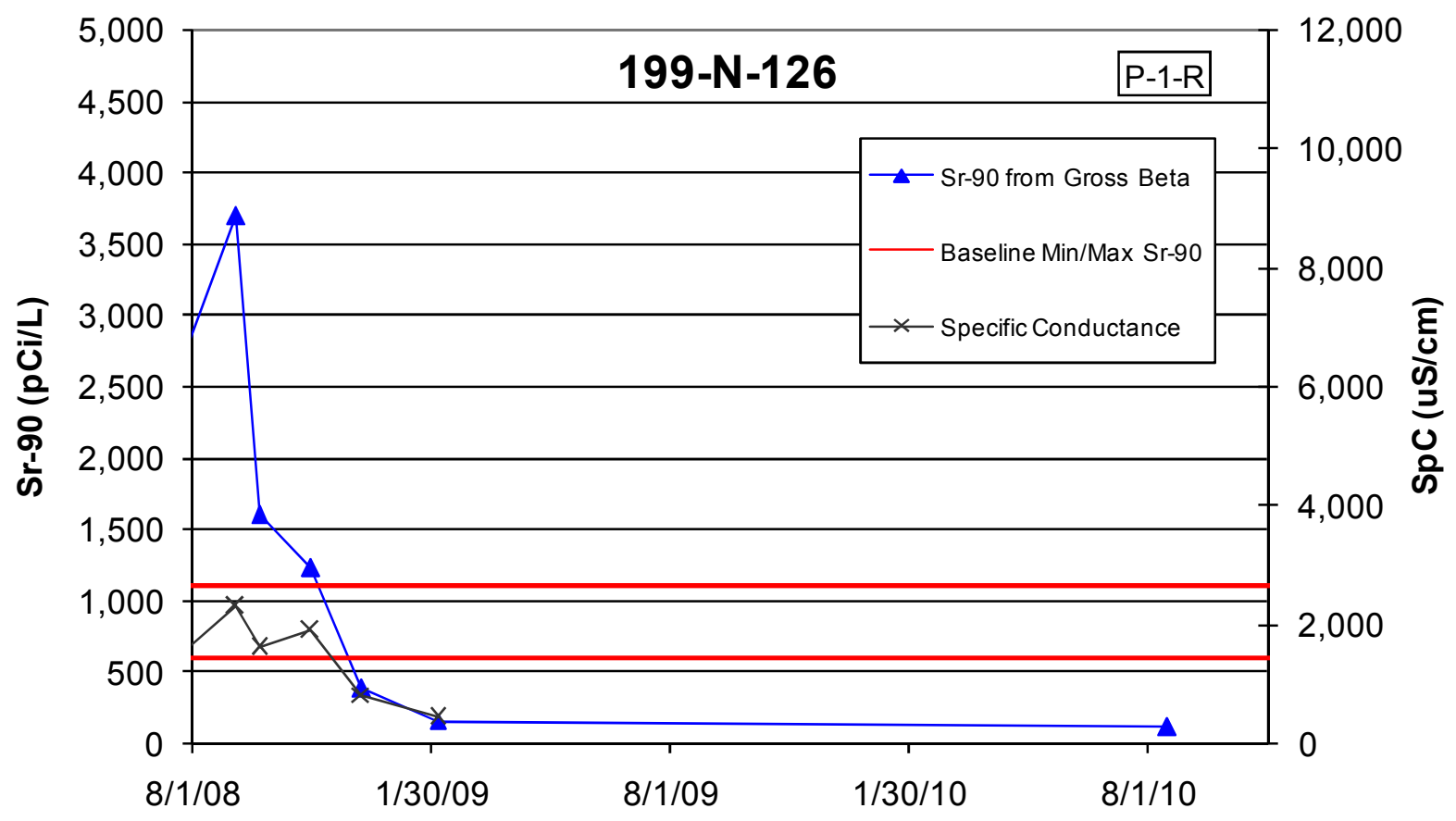

Figure C.2. Performance Plots for Well 199-N-126 (P-1-R)

No Samples Collected in 199-N-127 between August 2008 and October 2010.

Performance Plots for Well 199-N-127 (P-2-H) not included. 


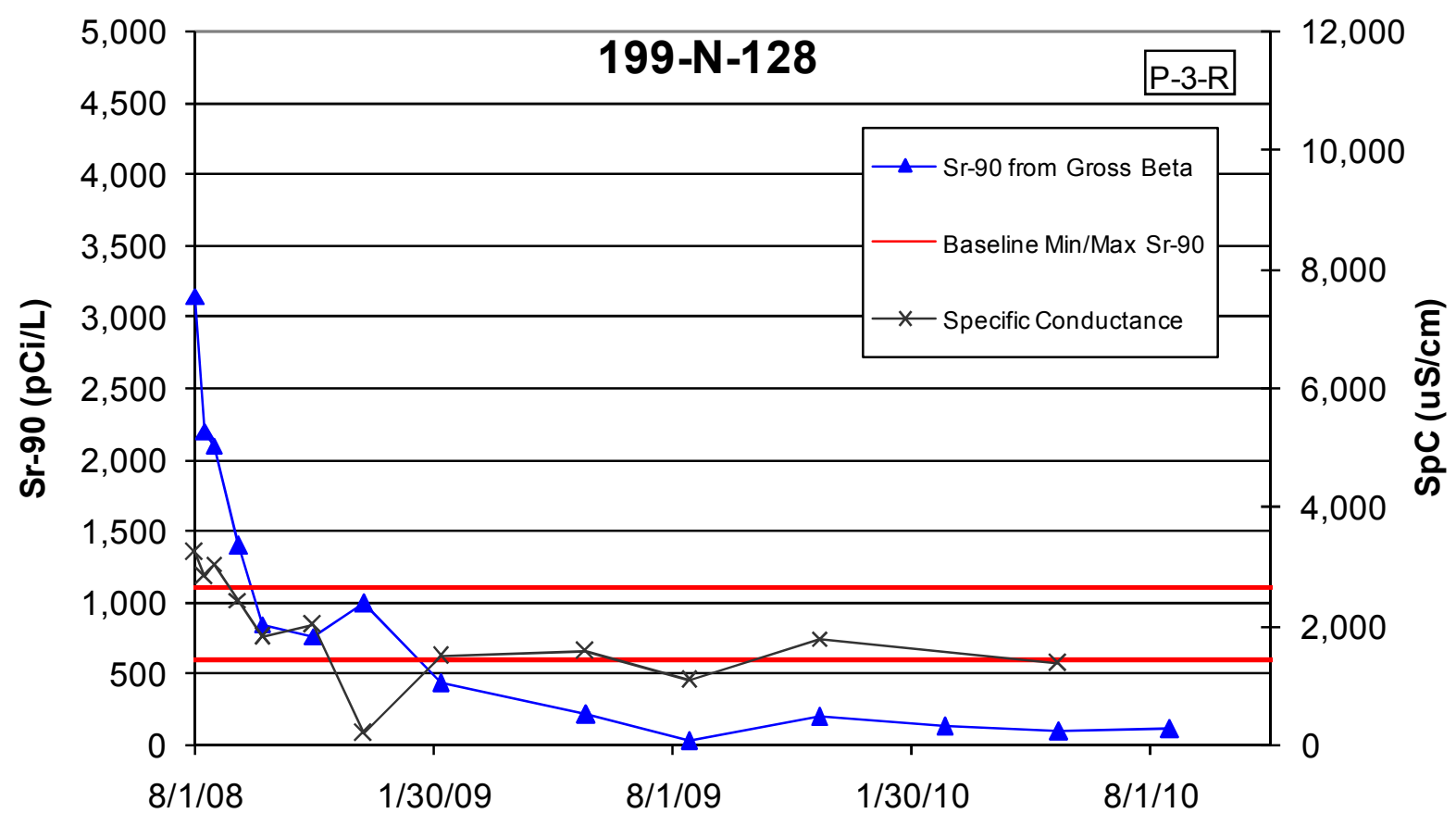

Figure C.3. Performance Plots for Well 199-N-128 (P-3-R)

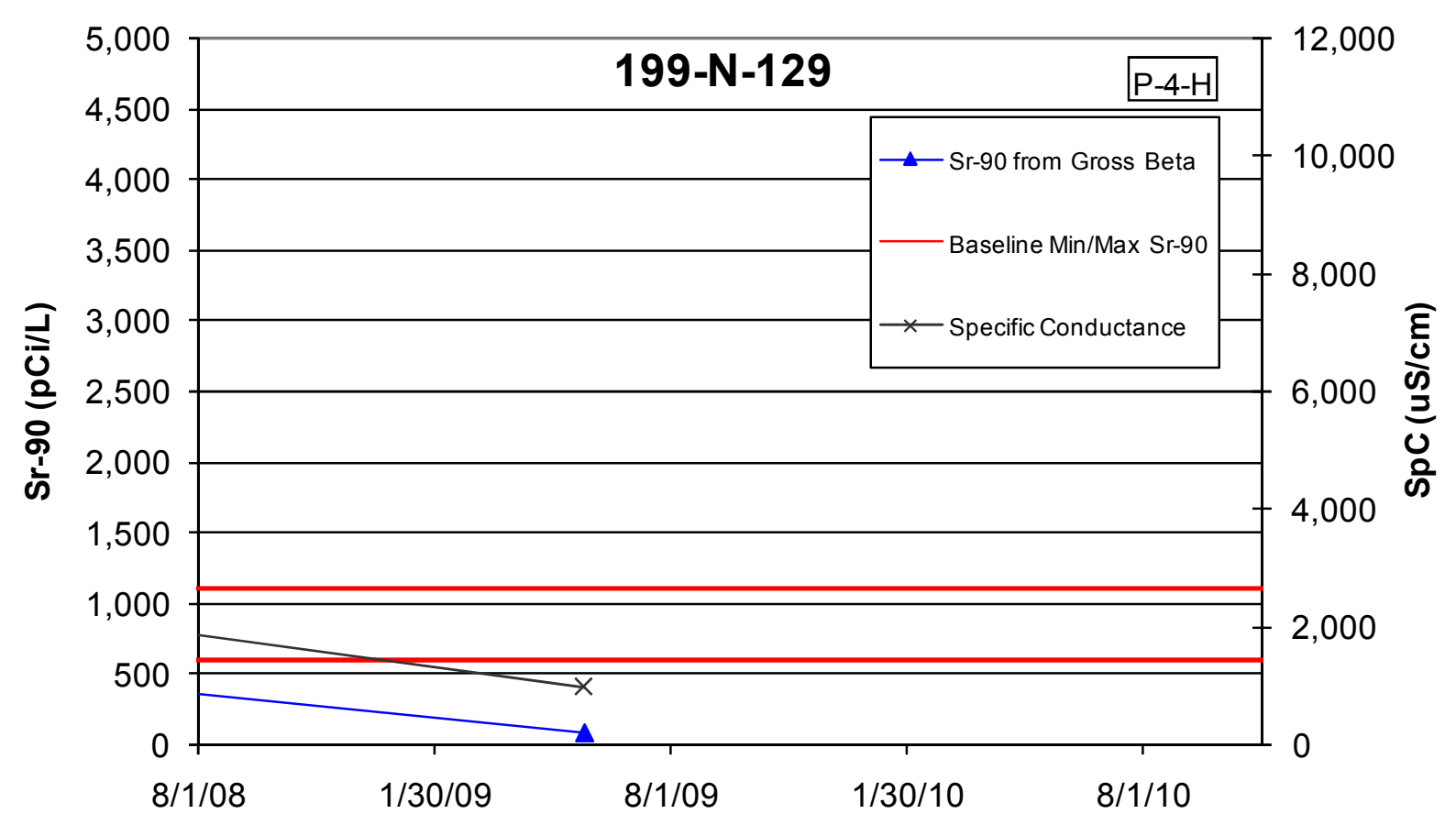

Figure C.4. Performance Plots for Well 199-N-129 (P-4-H) 


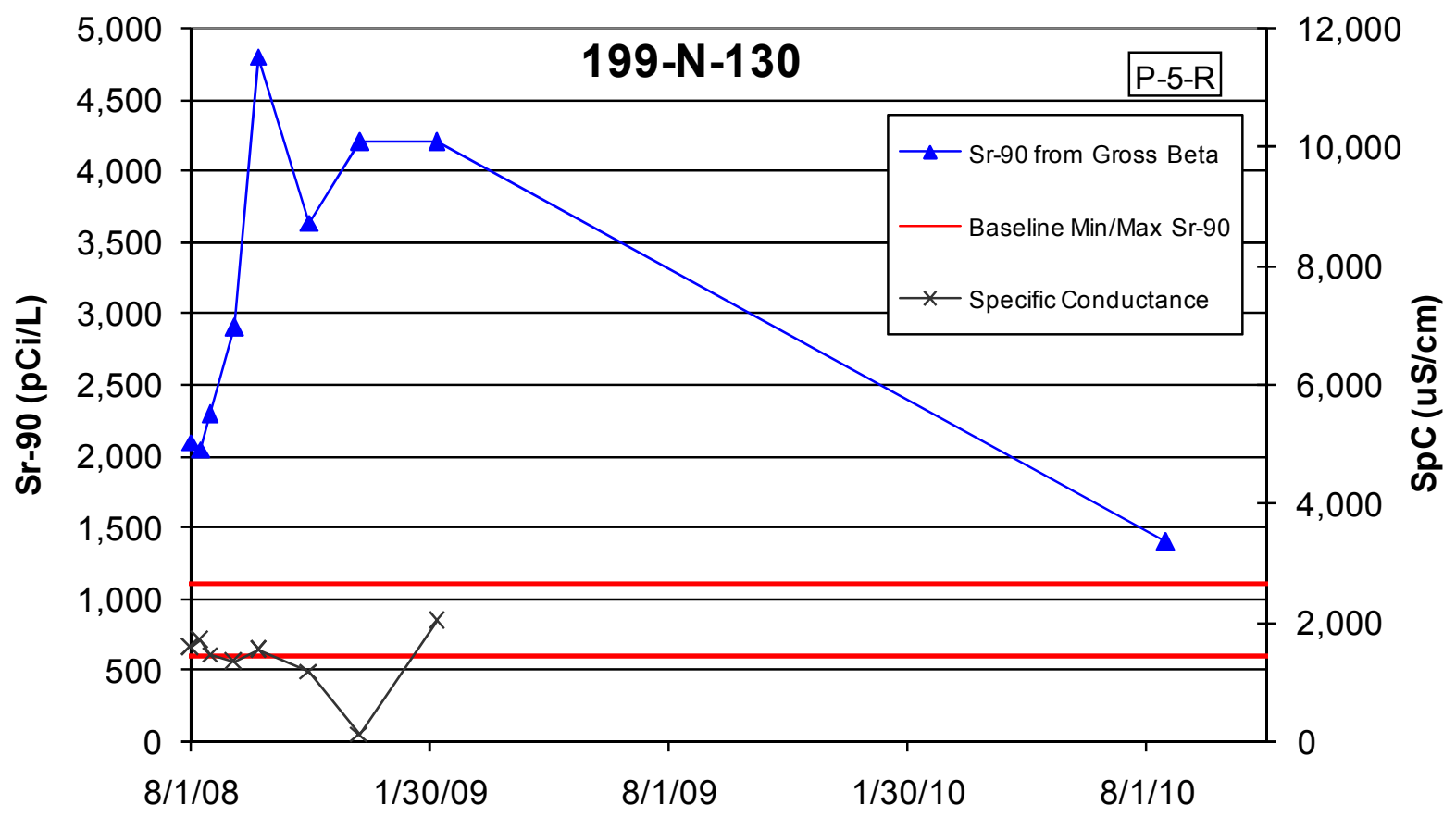

Figure C.5. Performance Plots for Well 199-N-130 (P-5-R)

No Samples Collected in 199-N-131 between August 2008 and October 2010.

Performance Plots for Well 199-N-131 (P-6-H) not included. 


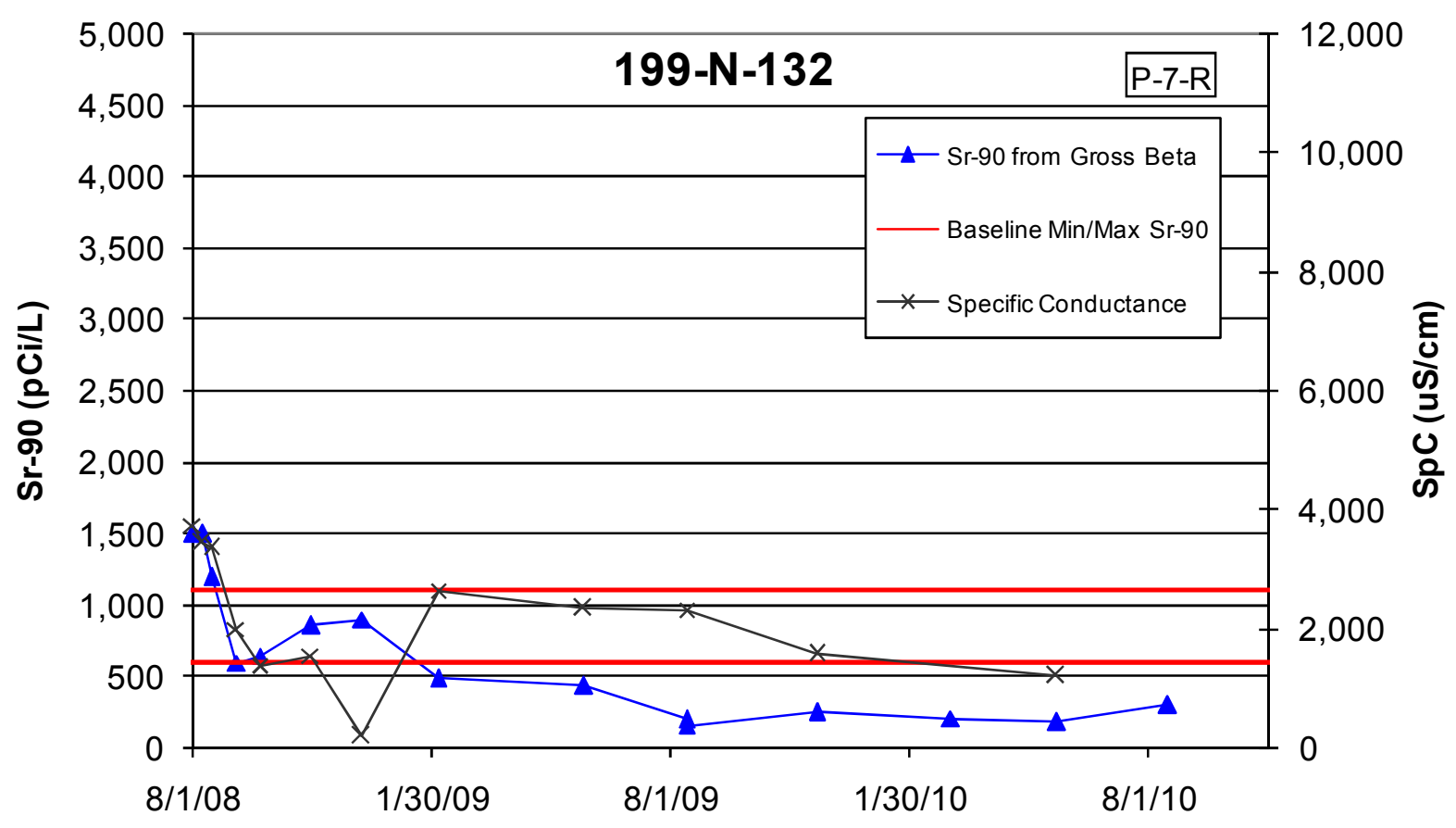

Figure C.6. Performance Plots for Well 199-N-132 (P-7-R)

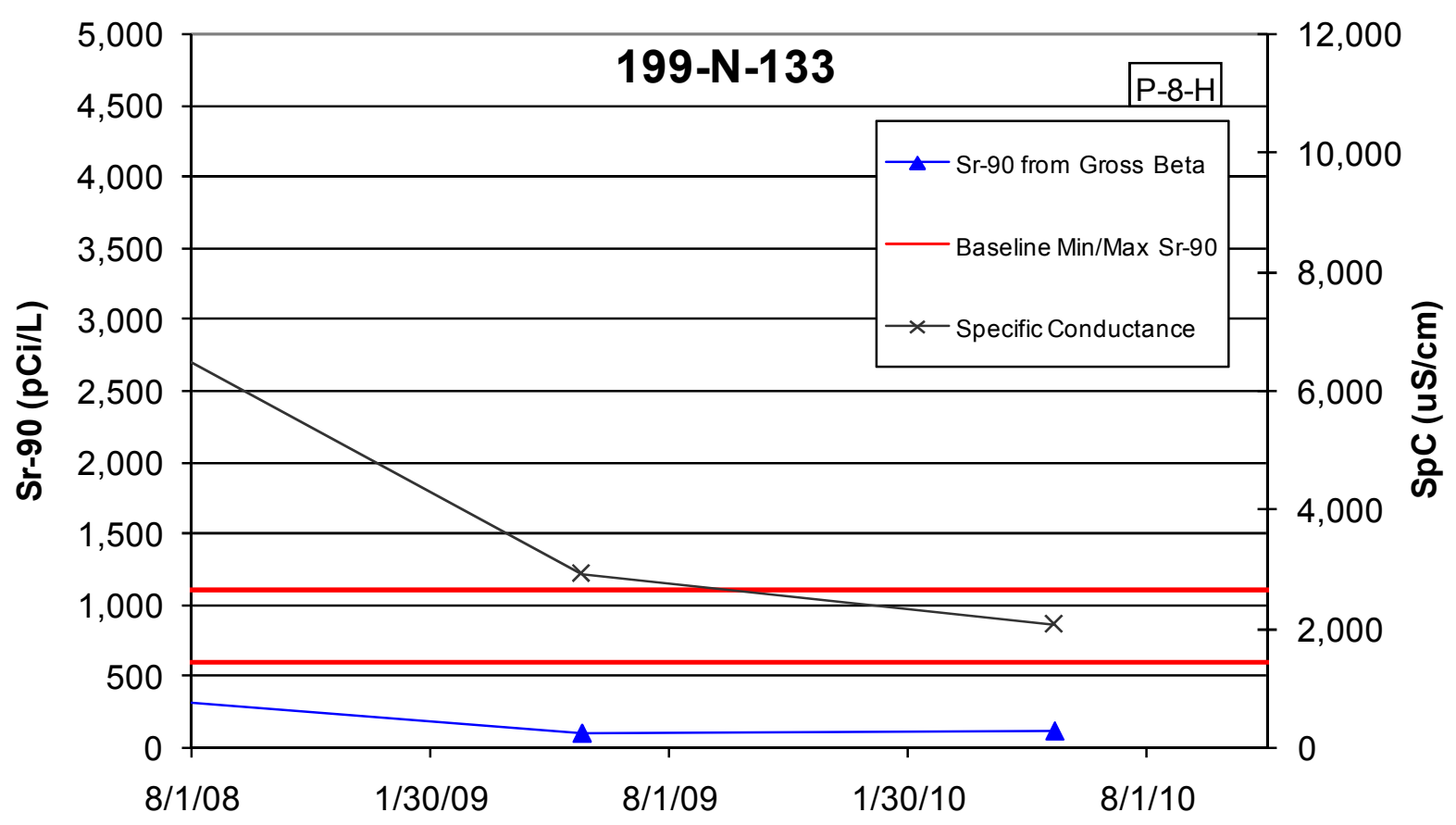

Figure C.7. Performance Plots for Well 199-N-133 (P-8-H) 


\section{C.2. Pilot Site 2}

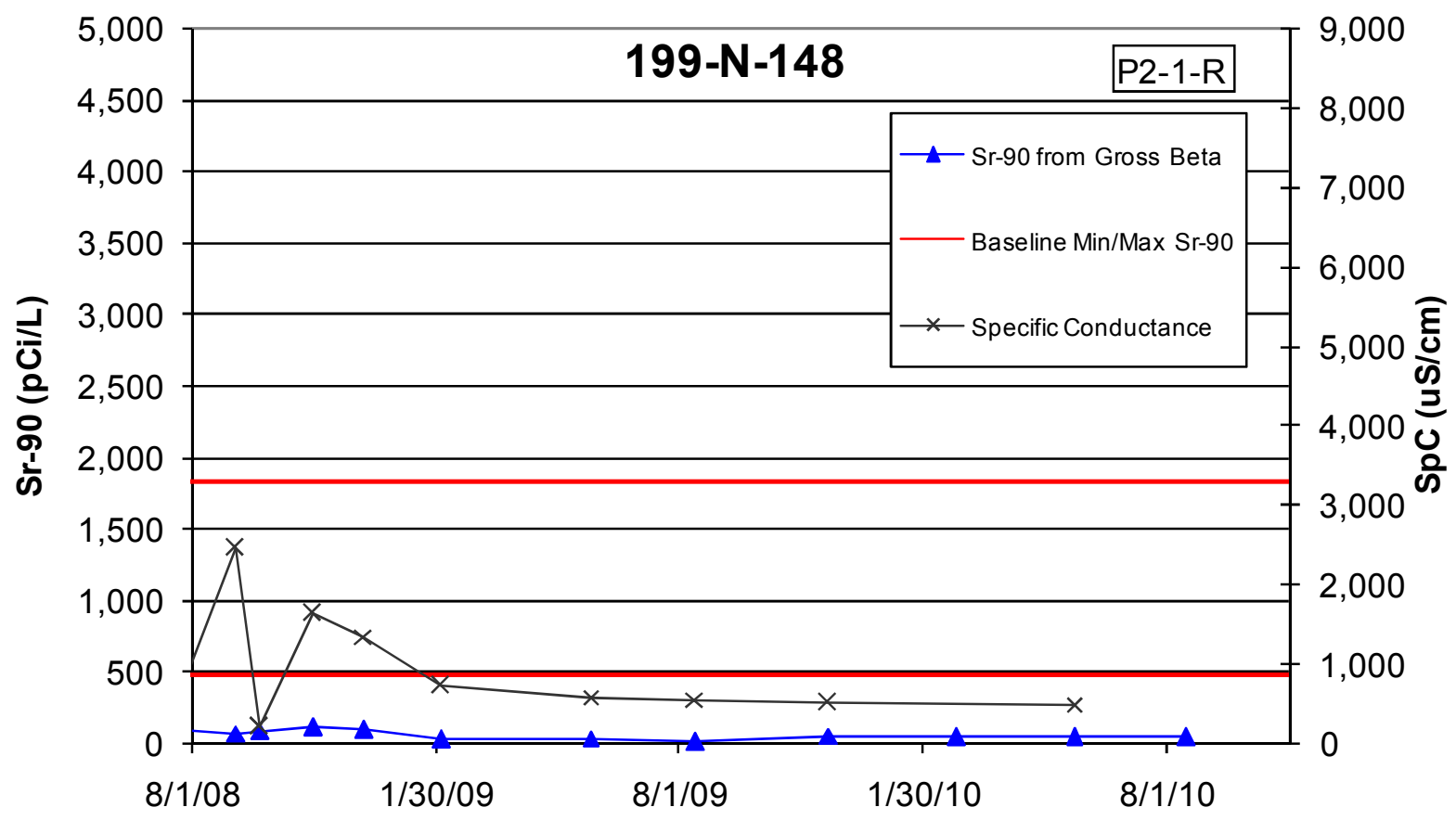

Figure C.8. Performance Plots for Well 199-N-148 (P2-1-R)

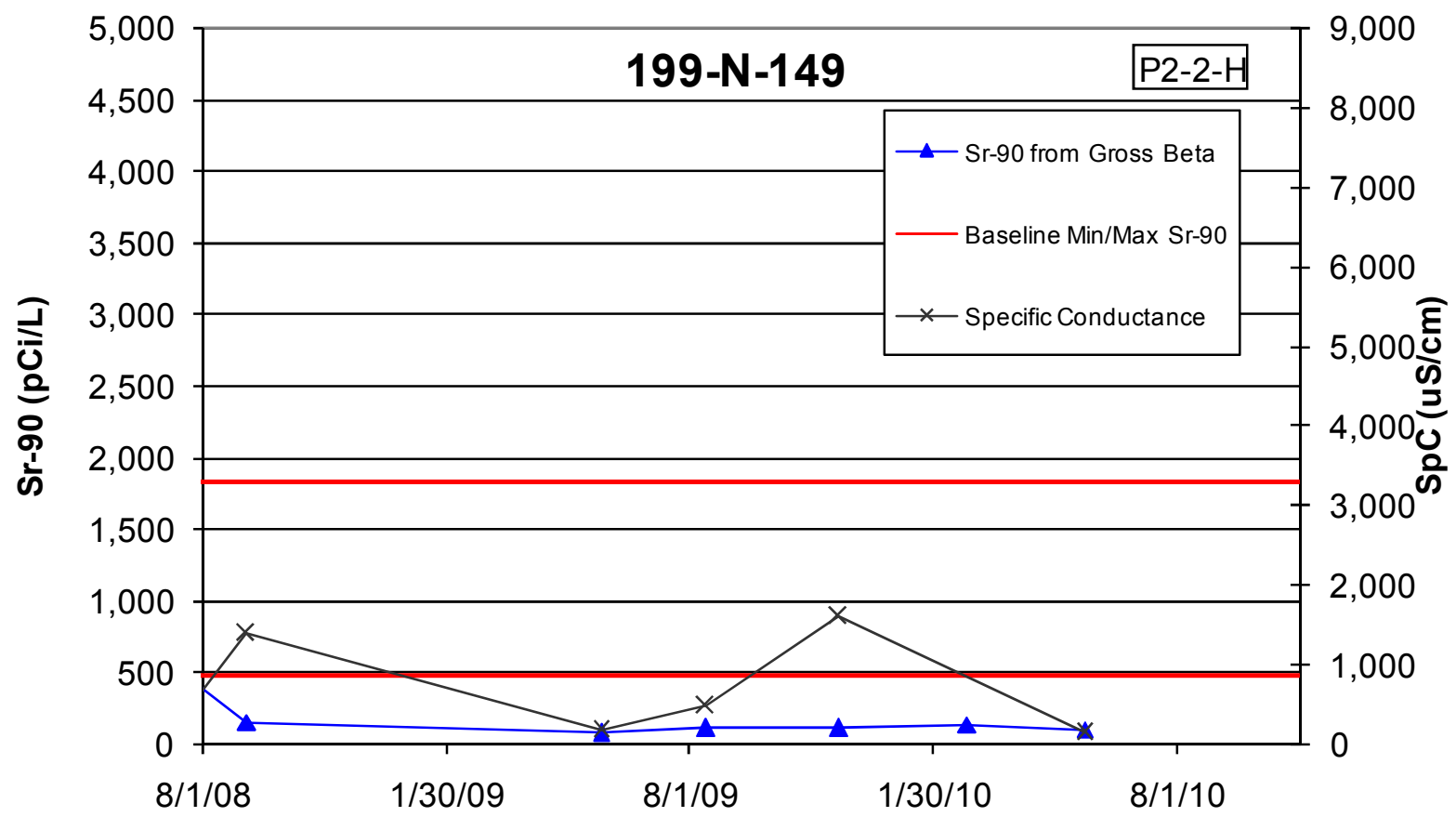

Figure C.9. Performance Plots for Well 199-N-149 (P2-2-H) 


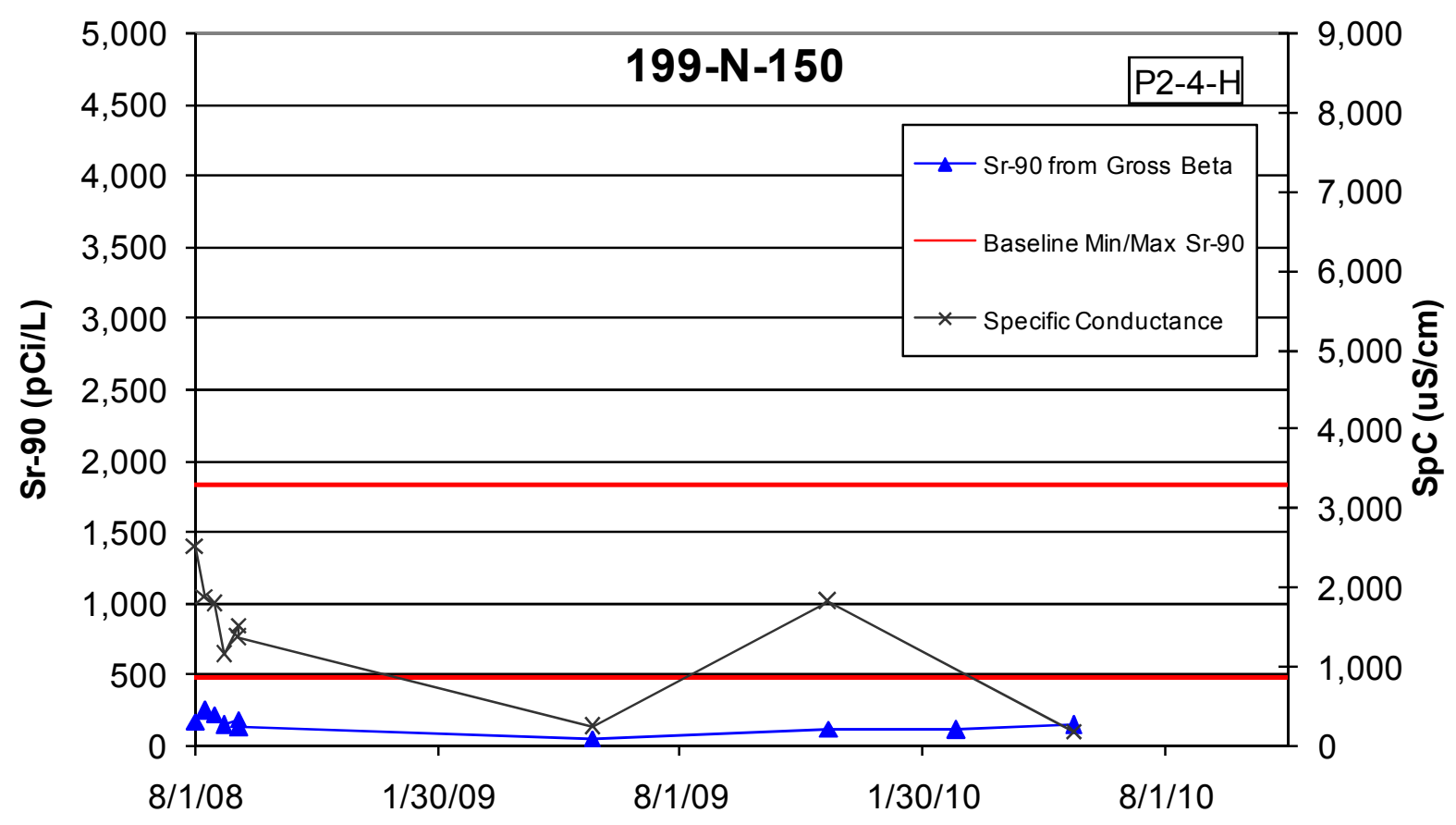

Figure C.10. Performance Plots for Well 199-N-150 (P2-4-H)

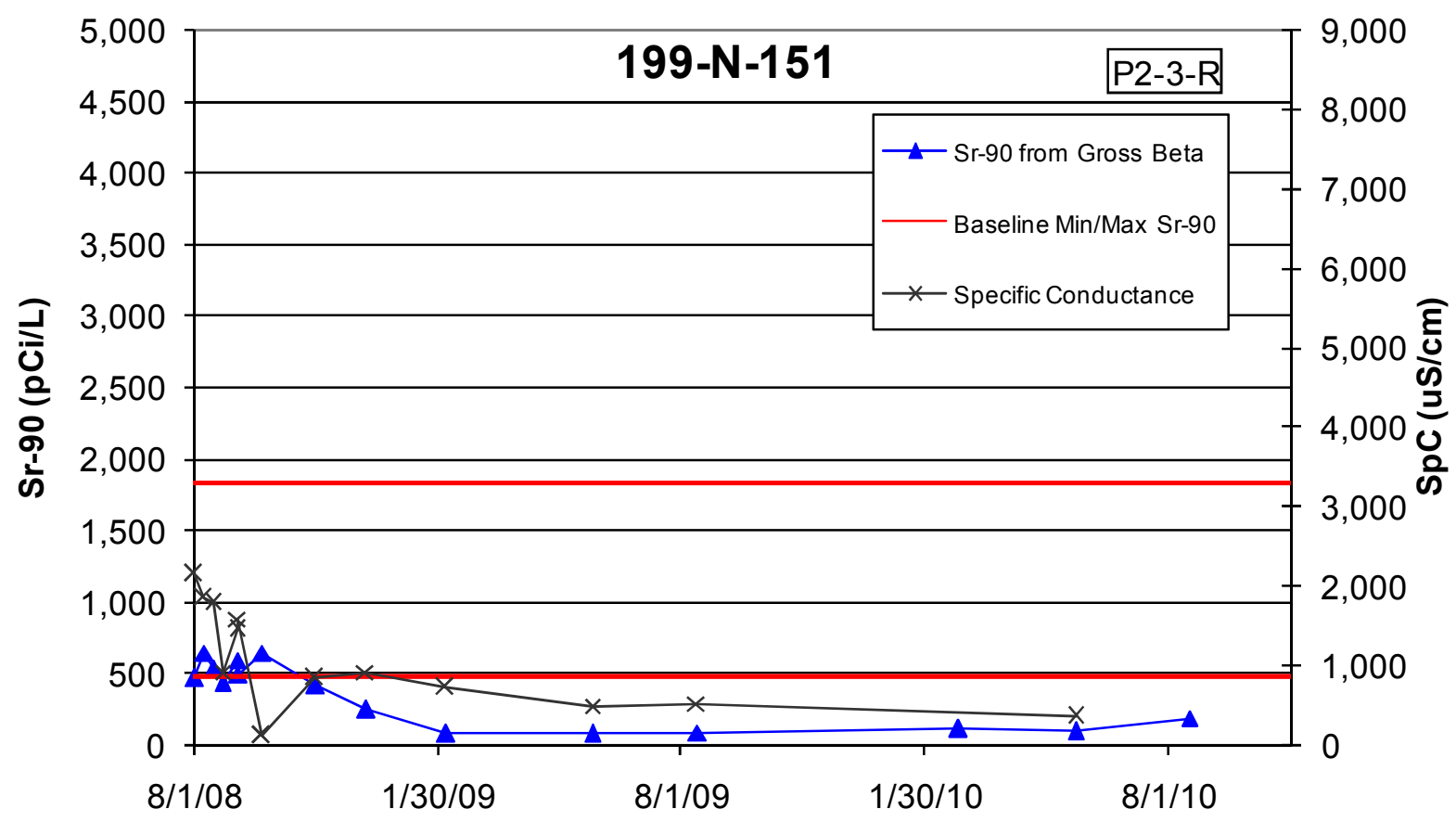

Figure C.11. Performance Plots for Well 199-N-151 (P2-3-R) 


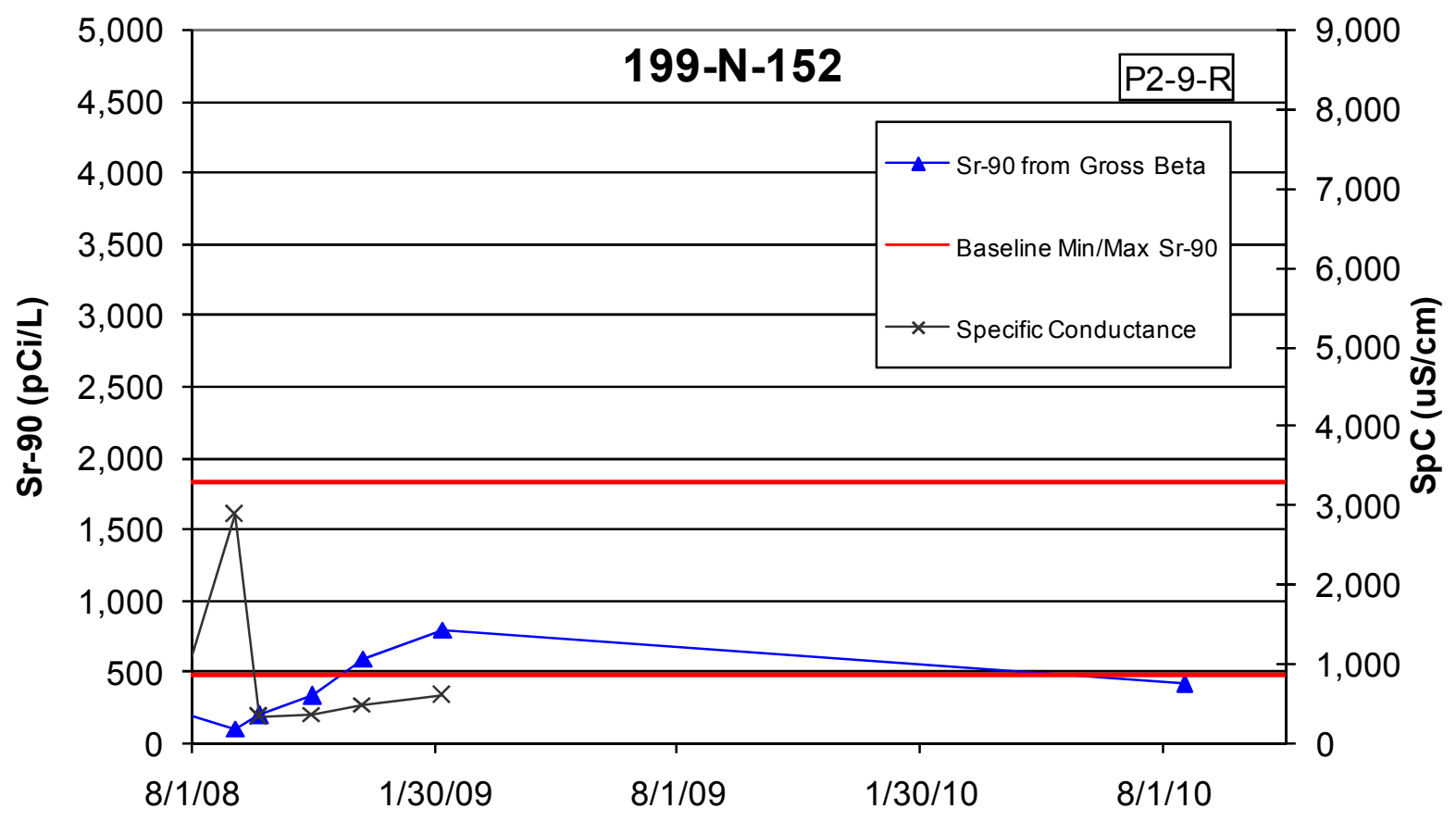

Figure C.12. Performance Plots for Well 199-N-152 (P2-9-R)

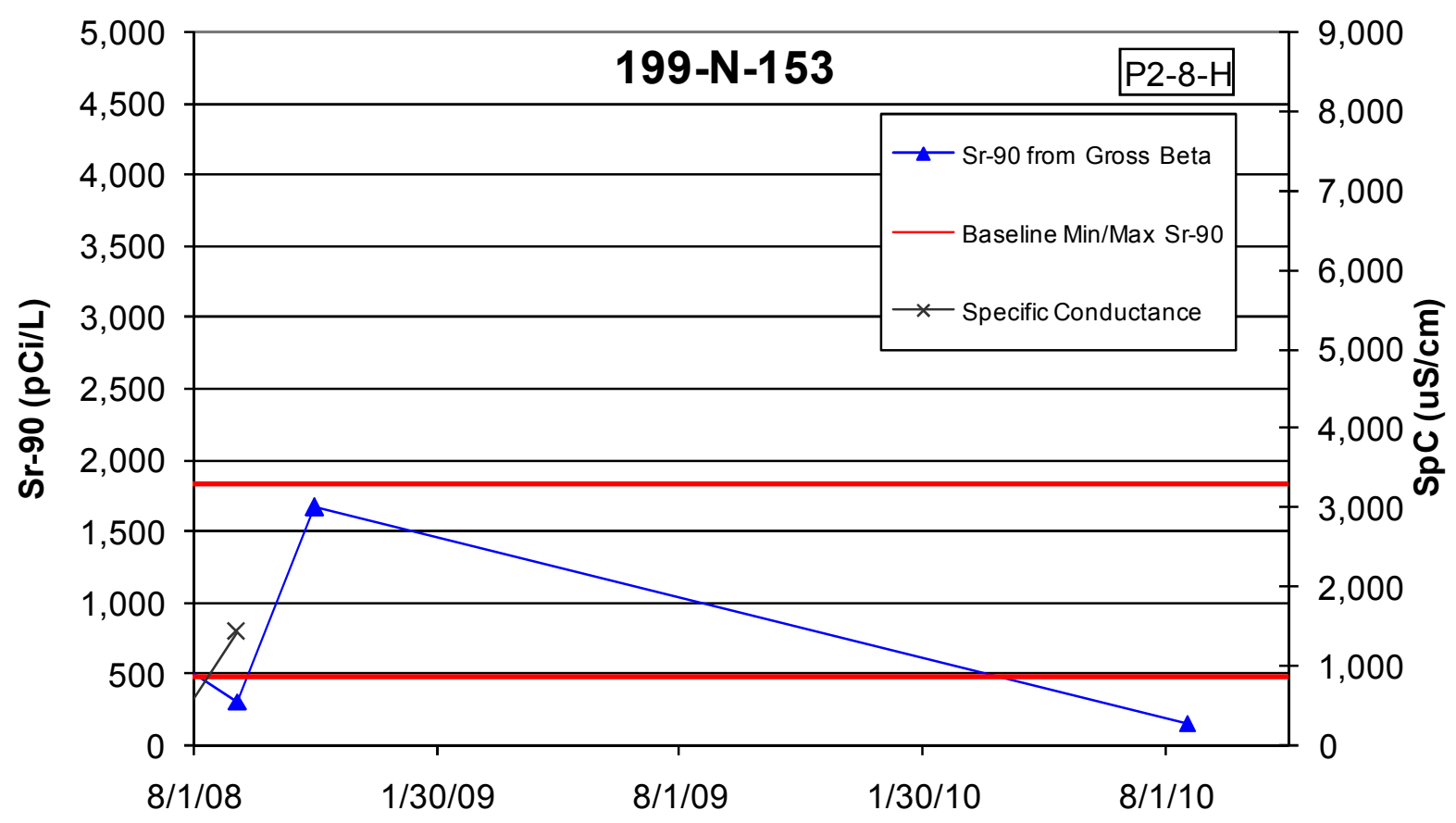

Figure C.13. Performance Plots for Well 199-N-153 (P2-8-H) 


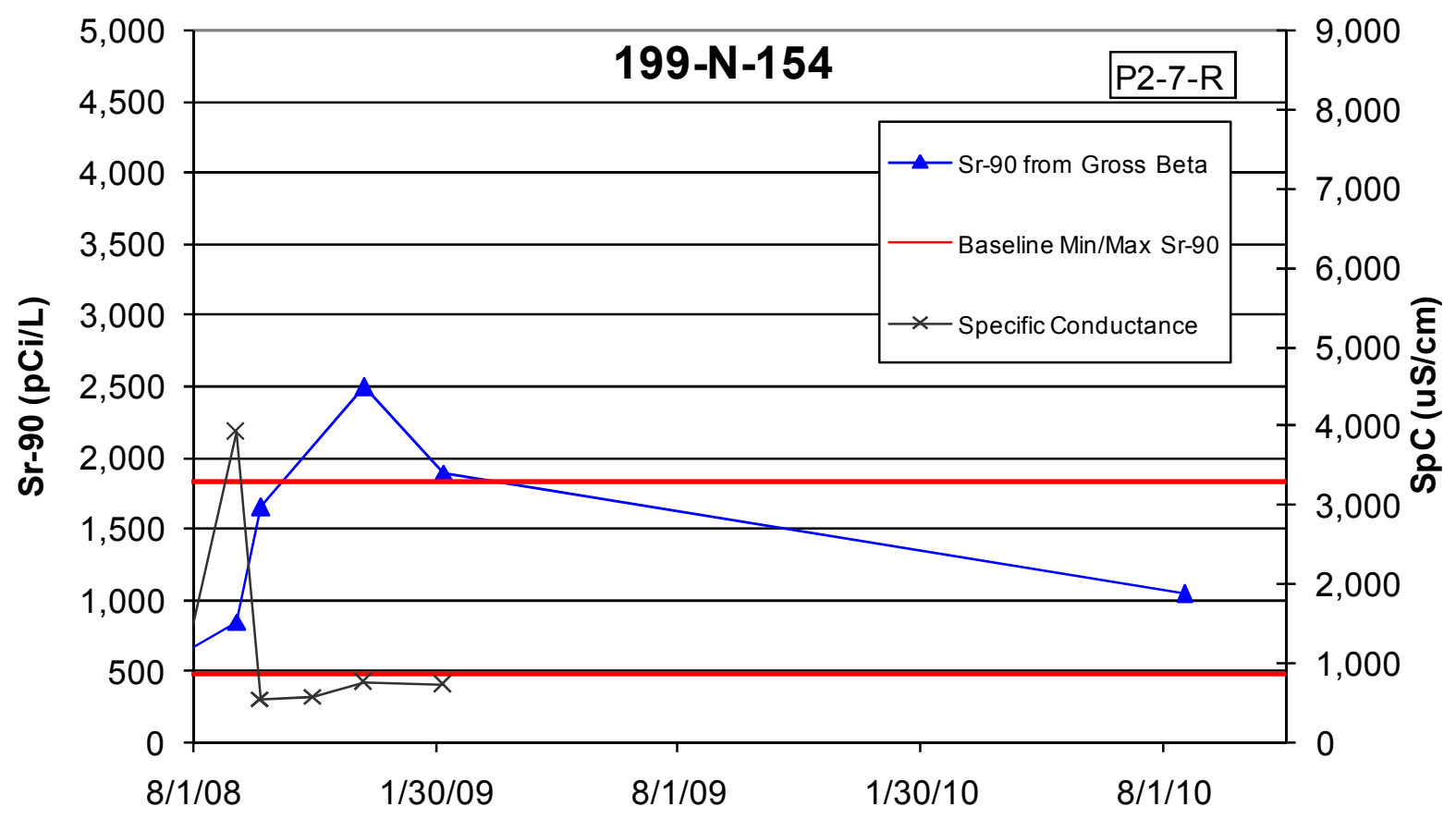

Figure C.14. Performance Plots for Well 199-N-154 (P2-7-R)

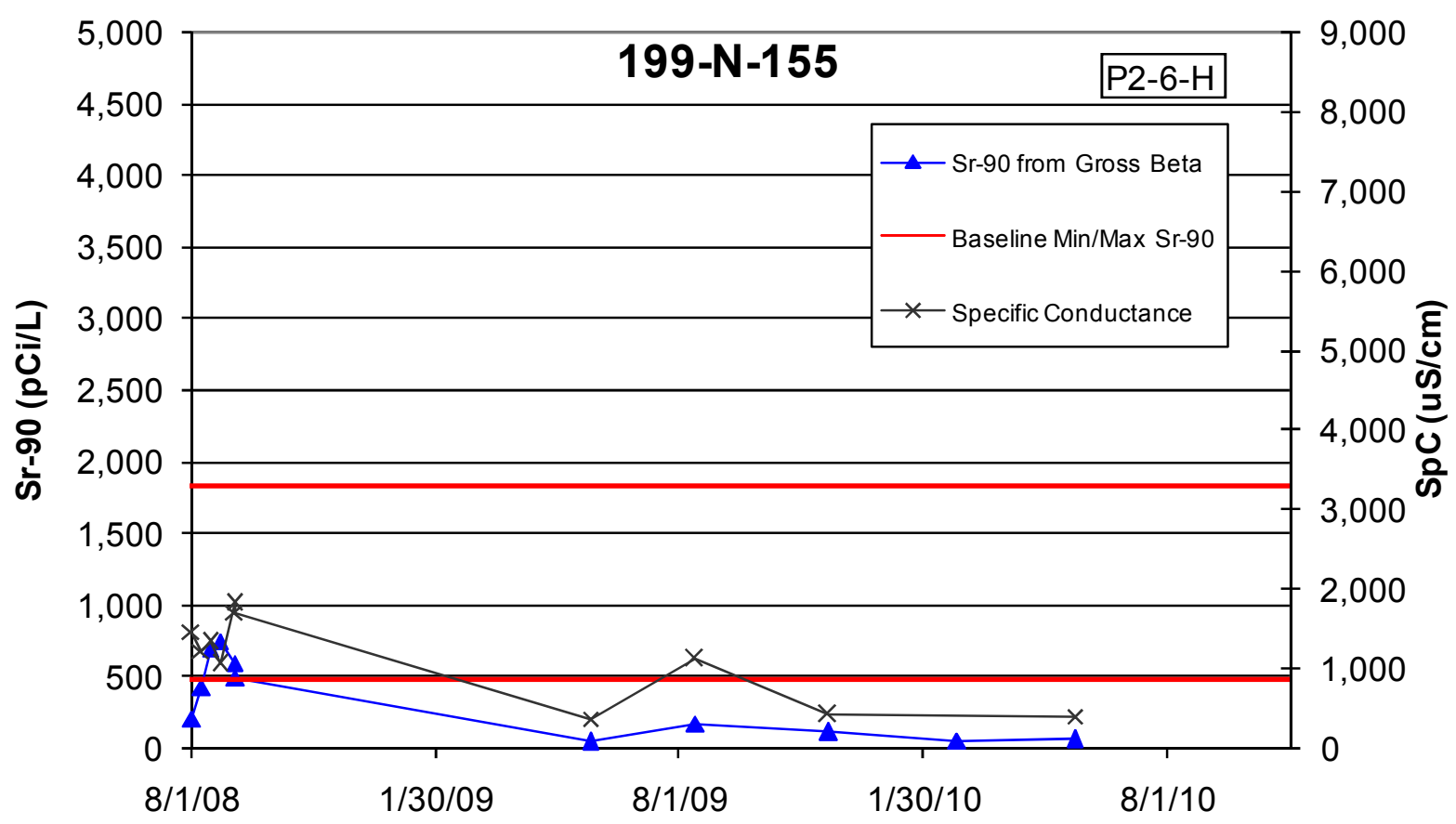

Figure C.15. Performance Plots for Well 199-N-155 (P2-6-H) 


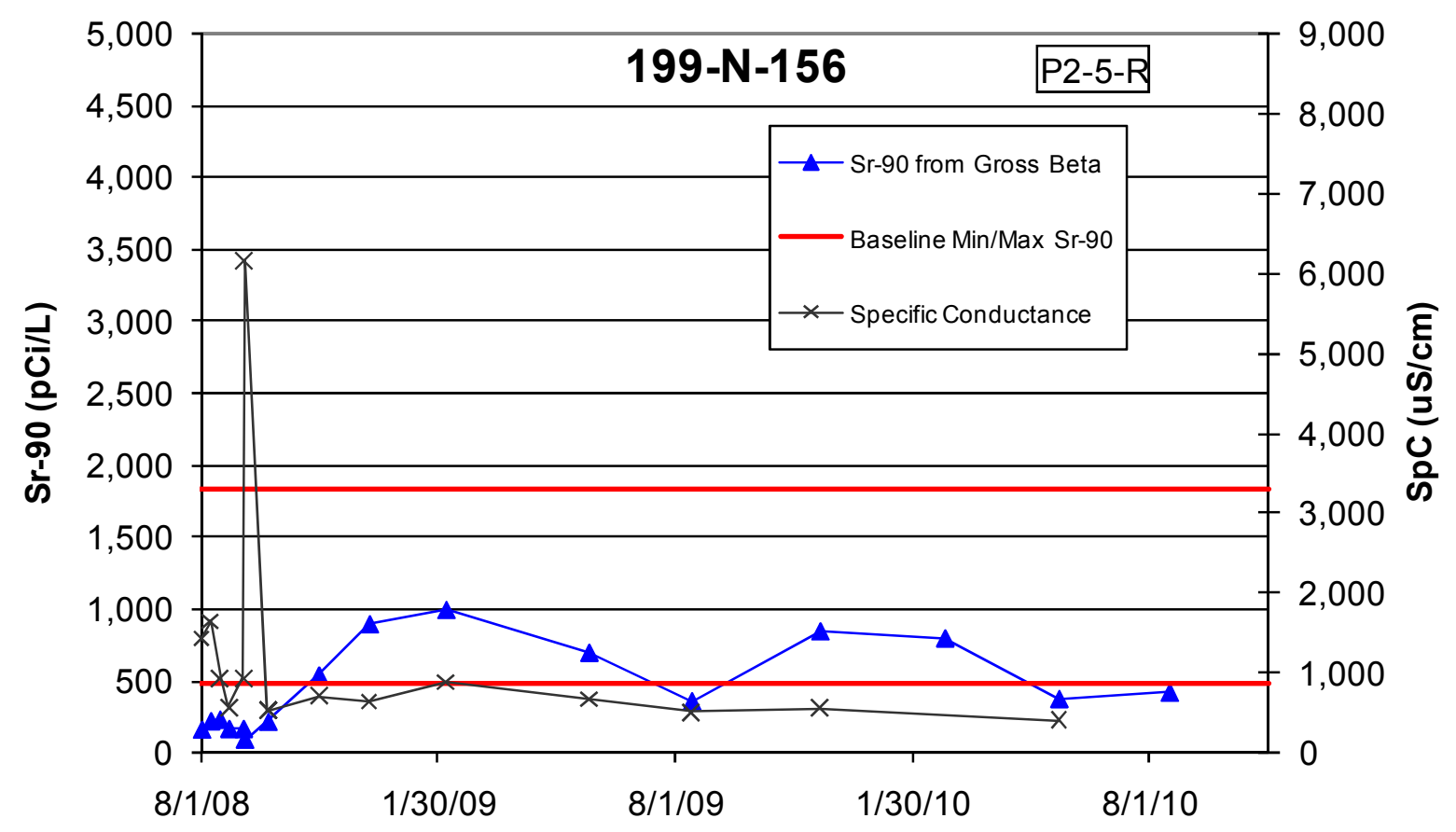

Figure C.16. Performance Plots for Well 199-N-156 (P2-5-R) 


\section{Appendix D}

\section{Barrier Performance: Aquifer Tubes-8/1/08 through 10/31/10}





\section{Appendix D: Barrier Performance: Aquifer Tubes- $8 / 1 / 08$ through $10 / 31 / 10$}

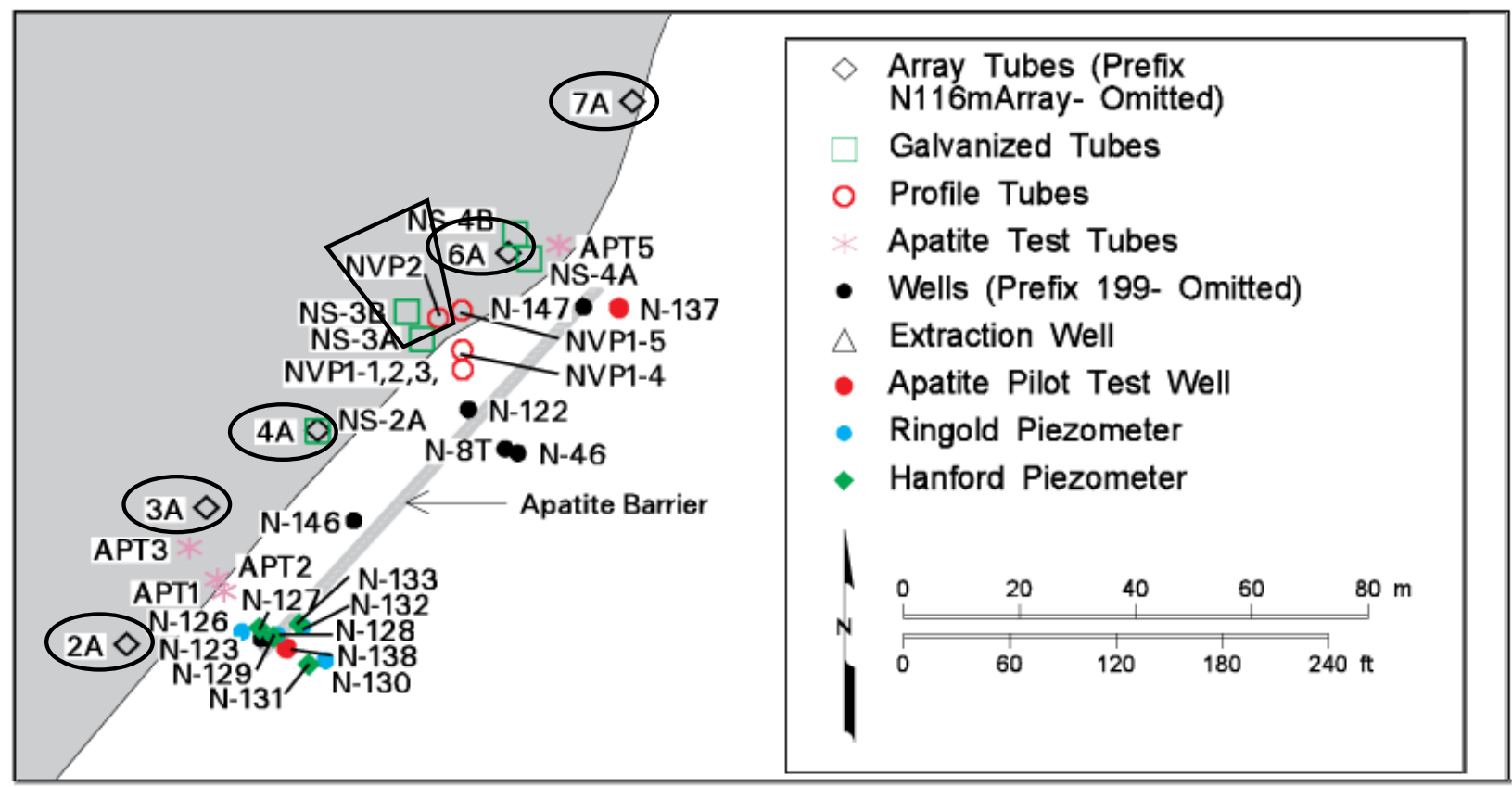

Figure D.1. Map of Aquifer Tube Locations

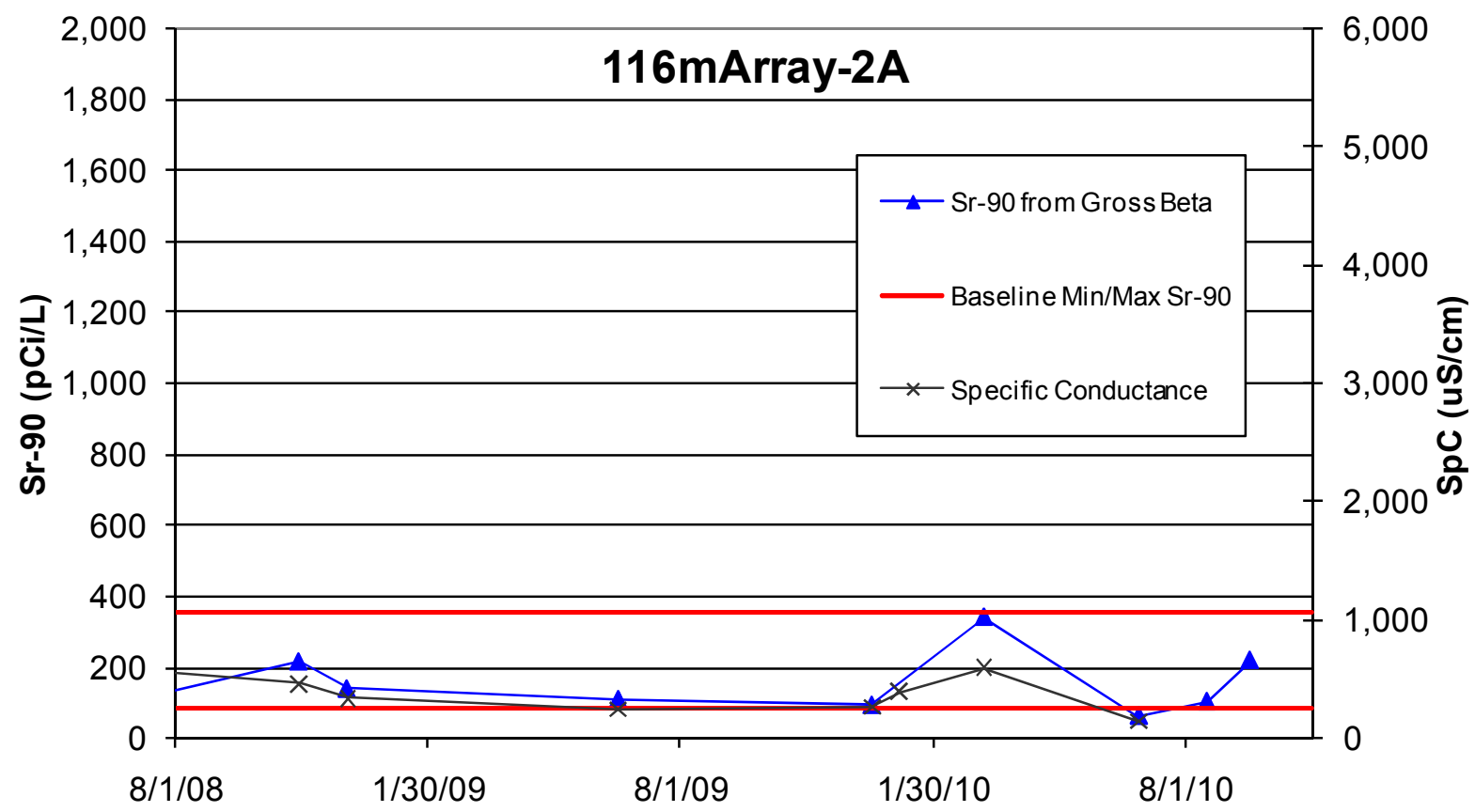

Figure D.2. Performance Plots for Tube 2A 


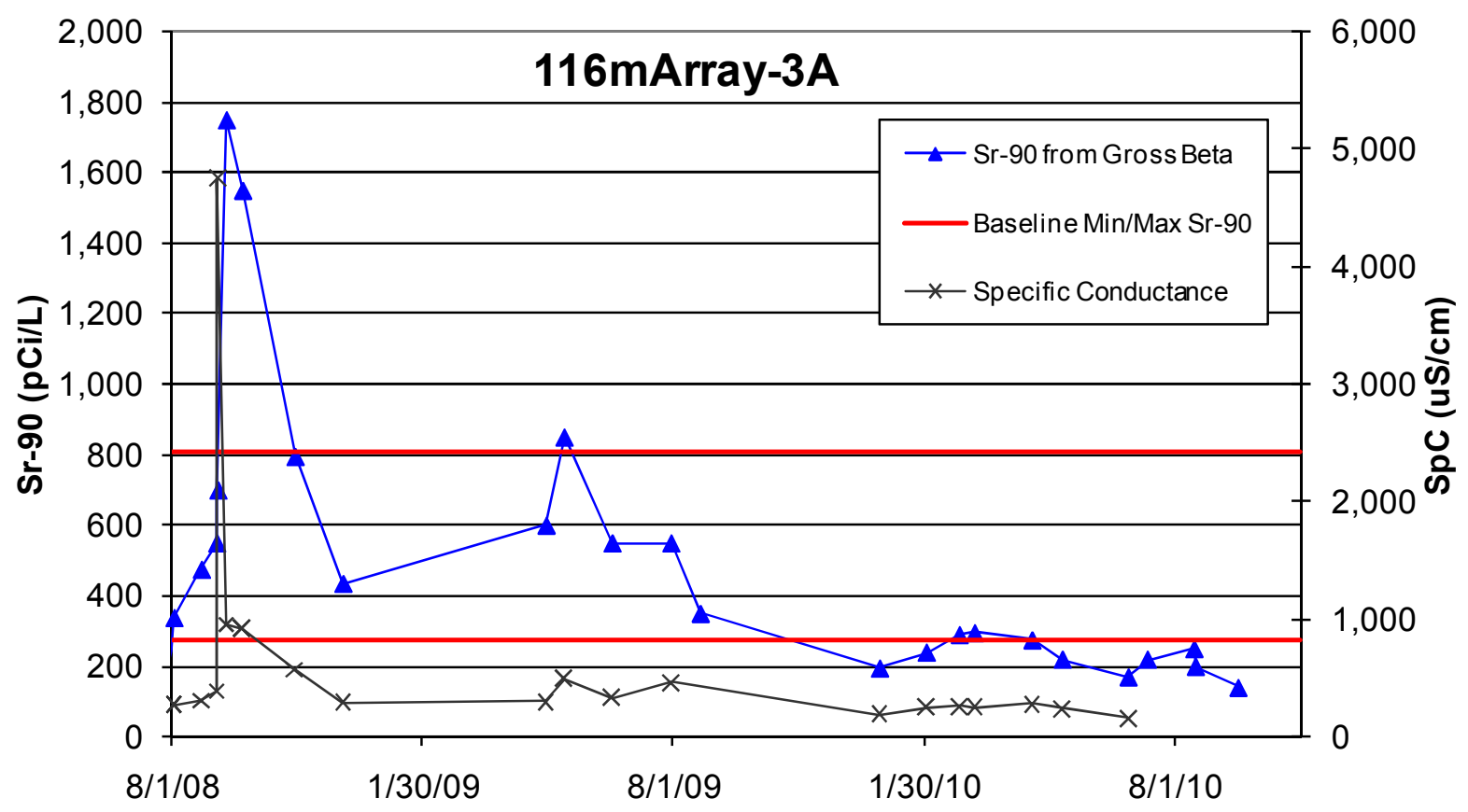

Figure D.3. Performance Plots for Tube 3A

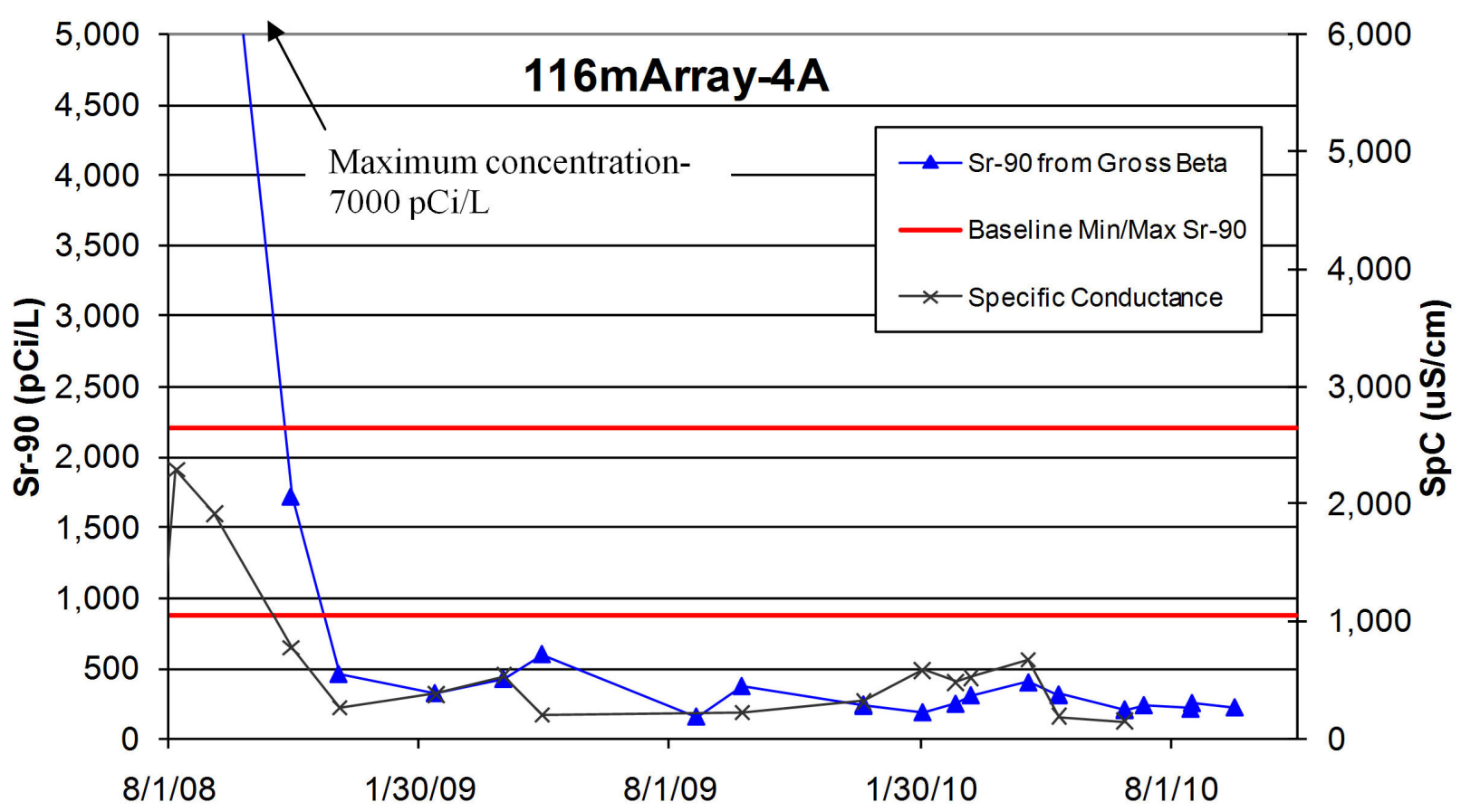

Figure D.4. Performance Plots for Tube 4A 


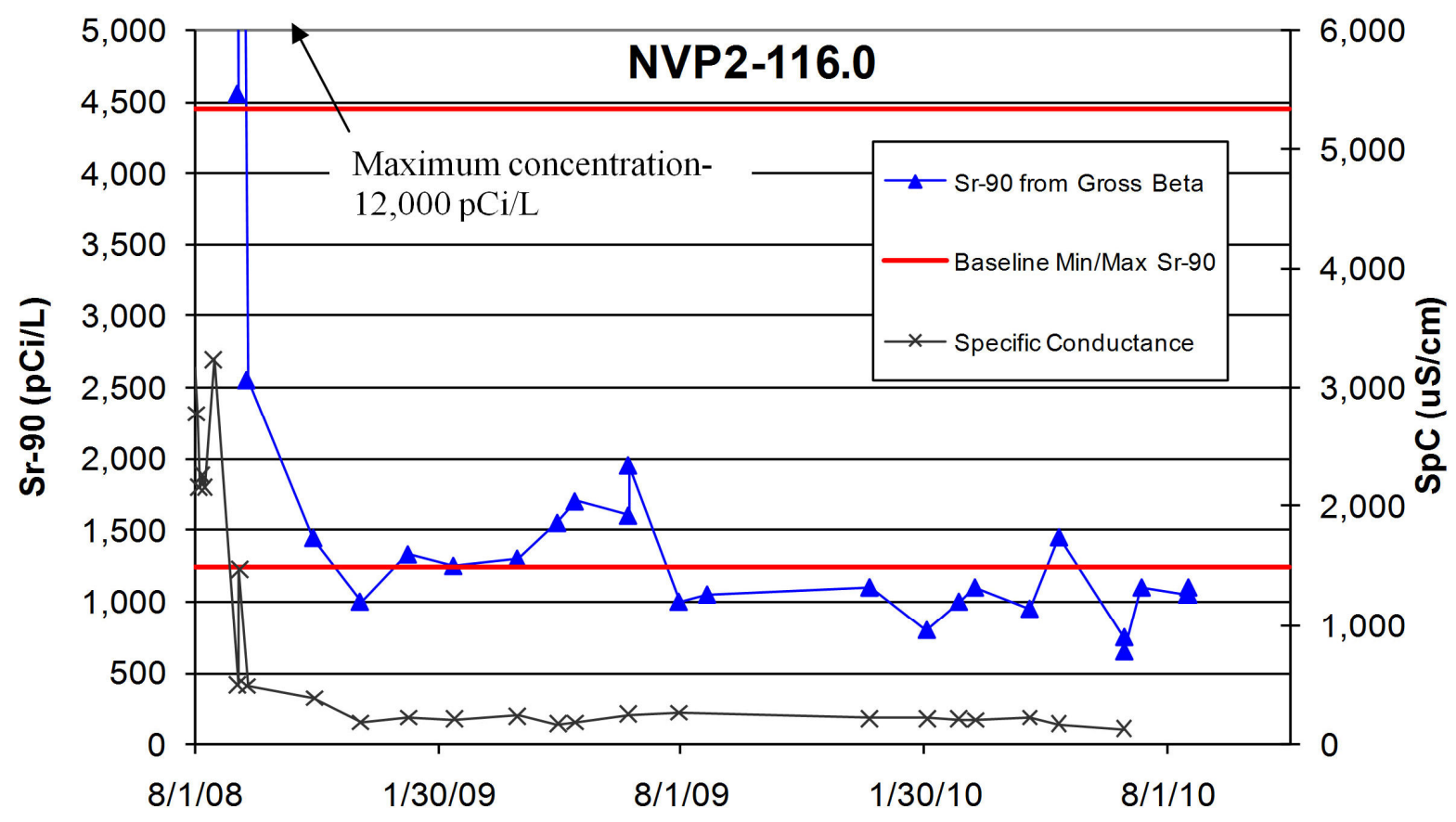

Figure D.5. Performance Plots for Tube NVP2-116.0m

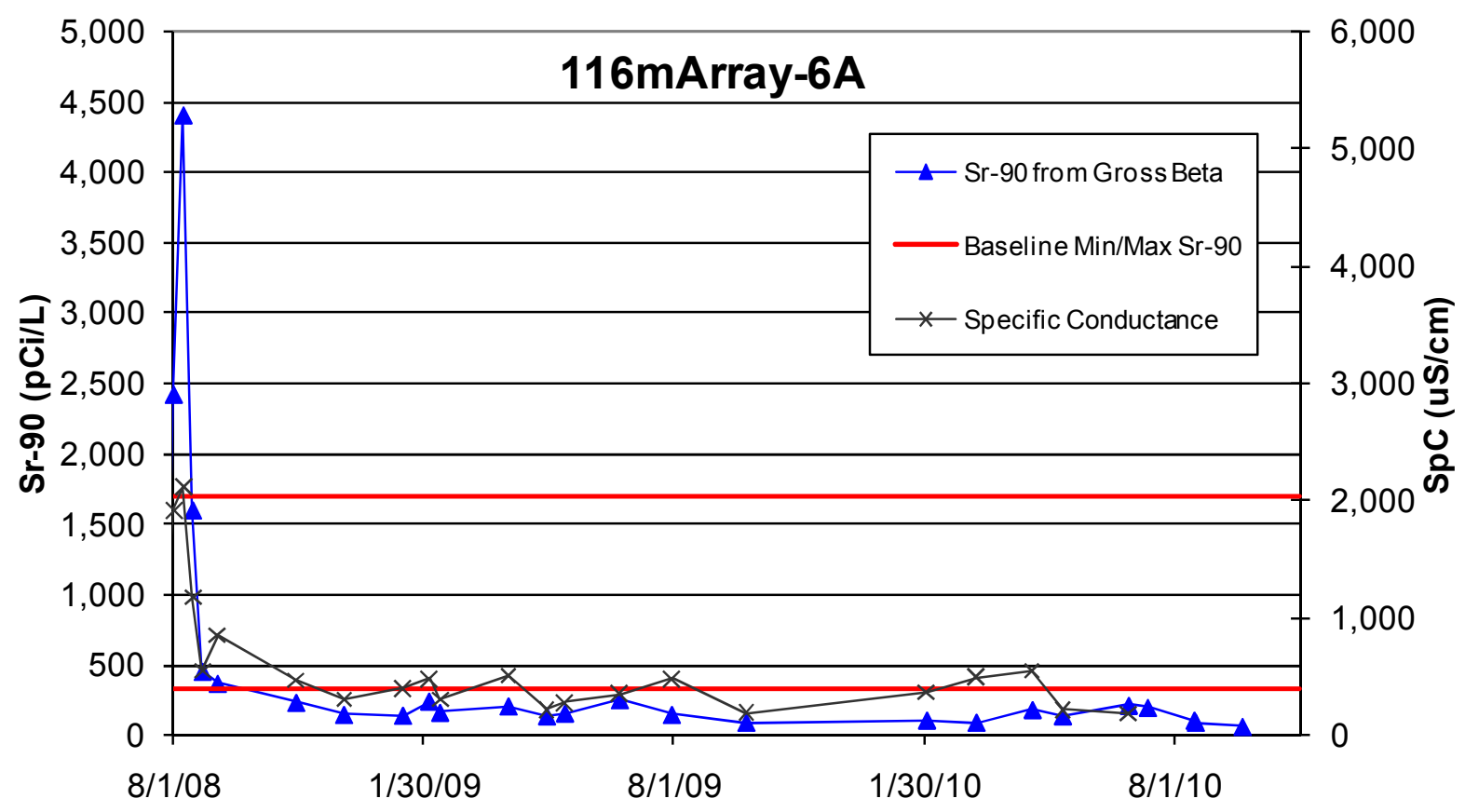

Figure D.6. Performance Plots for Tube 6A 


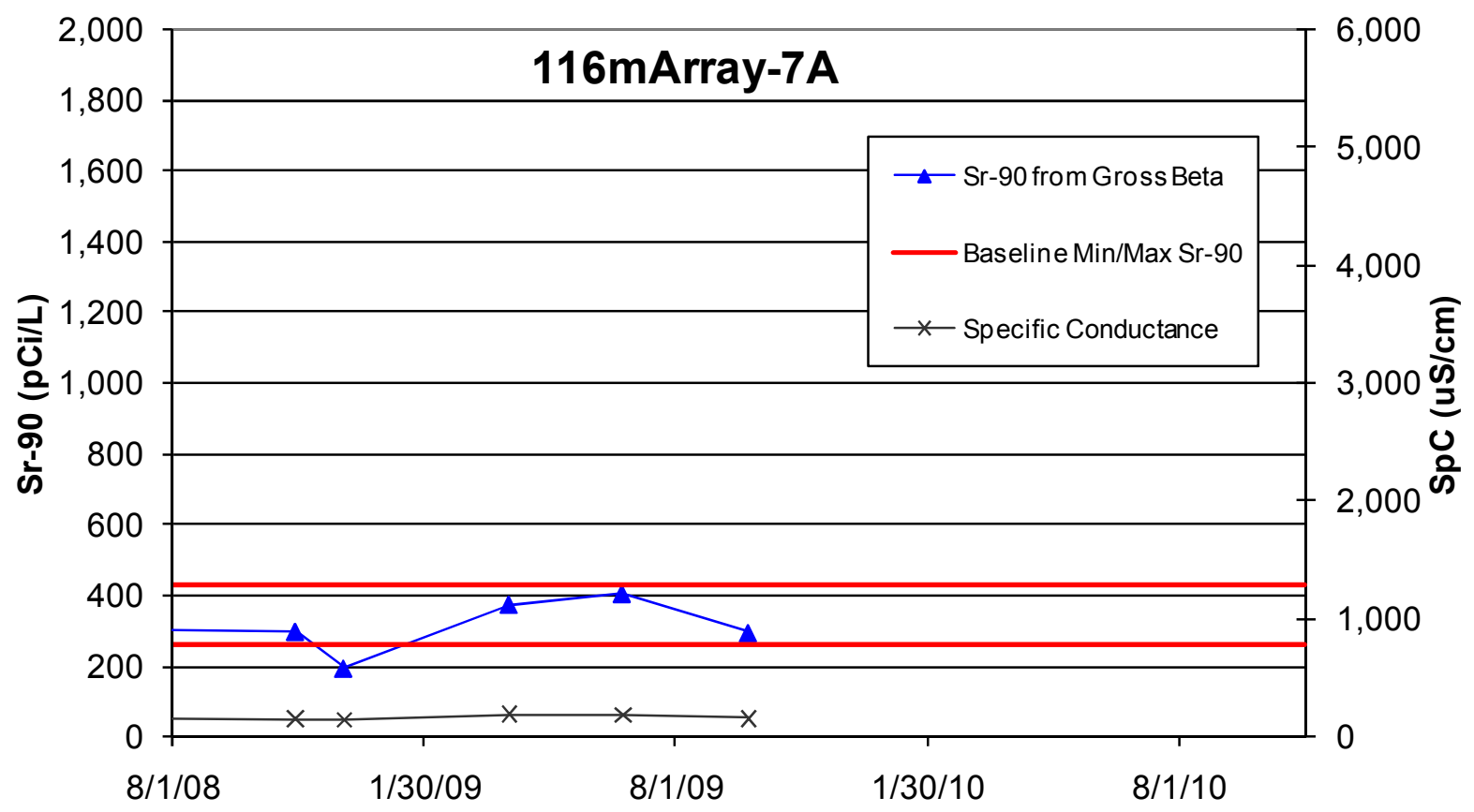

Figure D.7. Performance Plots for Tube 7A. This location was decommissioned in 2010 and replaced by two new aquifer tubes- C7881 and C7882. 


\section{Distribution}

No. of

$\underline{\text { Copies }}$

6 U.S. Department of Energy

JP Hanson

A5-11

M Thompson (5)

A6-38

5 CH2M Hill Plateau Remediation

Company

NA Bowles (5)
No. of

\section{Copies}

12 Pacific Northwest National Laboratory

BG Fritz

K6-75

JS Fruchter

K6-96

TJ Gilmore

K6-96

JE Szecsody

VR Vermeul (5)

K3-61

MD Williams

K6-96

Hanford Technical Library (2)
K6-96

P8-55 




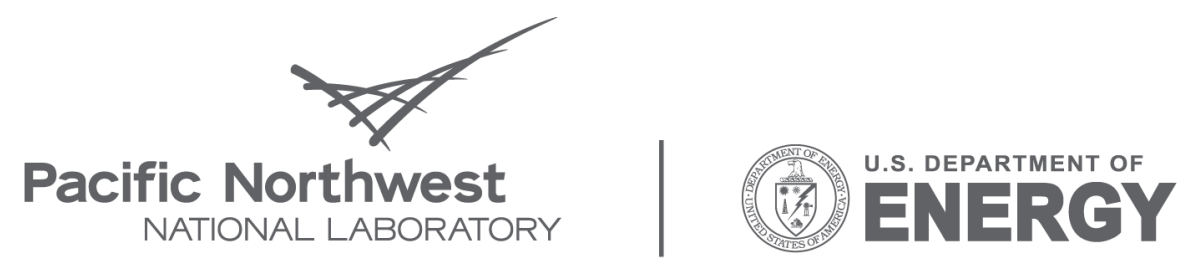

Proudly Operated by Battelle Since 1965

902 Battelle Boulevard

P.O. Box 999

Richland, WA 99352

1-888-375-PNNL (7665)

www.pnl.gov 